\title{
Geology of the
}

Western Part of the

Harold D. Roberts Tunnel,

Colorado

(Stations $0+00$ to $690+00$ )

GEOLOGICALSURVEY PROFESSIONAL PAPER 831-C 



\section{Geology of the Western Part of the Harold D. Roberts Tunnel, Colorado (Stations $0+00$ to $690+00$ )}

By ERNEST E. WAHLSTROM, CHARLES S. ROBINSON, and V. QUENTIN HORNBACK

ENGINEERING GEOLOGY OF THE HAROLD D. ROBERTS TUNNEL, COLORADO

G E O L O G I C A L S U R V E Y P R O FES S I O N A L P A P E R 831-C

A description of the geology of and engineering practices used in the western part of the tunnel

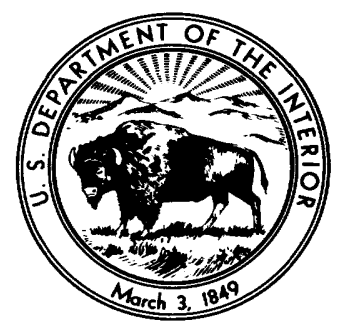




\title{
UNITED STATES DEPARTMENT OF THE INTERIOR
}

\author{
JAMES G. WATT, Secretary
}

\section{GEOLOGICAL SURVEY}

\author{
Doyle G. Frederick, Acting Director
}

Library of Congress Cataloging in Publication Data

Wahlstrom, Ernest Eugene, 1909-

Geology of the western part of the Harold D. Roberts Tunnel, Colorado (Stations $0+00$ to $690+00$ )

(Engineering geology of the Harold D. Roberts Tunnel, Colorado)

(Geological Survey Professional Paper 831-C)

Bibliography: p. 58

Supt. of Docs. no.: 1 19.16:831-C

1. Geology-Colorado-Harold D. Roberts Tunnel. 2. Engineering geology-Colorado-Harold D. Roberts

Tunnel. I. Robinson, Charles Sherwood, 1920- joint author. II. Hornback, V. Quentin, joint author.

III. Title. IV. Series. V. Series: United States Geological Survey Professional Paper 831-C.

QE92.H37W33

557.88

78-606037

For sale by the Superintendent of Documents, U.S. Government Printing Office

Washington, D.C. 20402 


\section{CONTENTS}

Abstract .

Introduction

\section{Stations 0+00 to $180+00$ Sedimentary Rocks}

Geology

Rock units

Sedimentary rocks

Maroon Formation

Lykins Formation

Entrada (?) Sandstone

Morrison Formation

Dakota Group

Benton Shale

Niobrara Formation

Pierre Shale

Igneous rocks

Structural geology

Engineering practices in relation to geology

Payline and overbreak

Shapes of tunnel cross sections

Feeler holes, ground water, and grouting

Supports

Progress

Occurrence of natural gas

Geology of the emergency gate shaft

Stations $180+00$ to $291+60$

Williams Range Thrust Plate

Geology

Rock units

Precambrian rocks

Aplite and pegmatite

Biotite gneiss

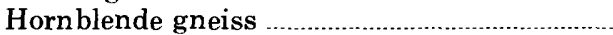

Quartzite

Tertiary rocks

Felsite porphyry

Breccia and mylonite

Structure

Foliation

Faults

Williams Range thrust fault

Other faults and joints

Page
C1
2



5
5
5
5
5
7
7
8
8
9
9
9
10
11
11
14
16
17
19
20
20

\section{Geology-Continued}

Structure-Continued

Structural evolution of the Williams Range thrust fault

Alteration

Engineering practices in relation to geology …................... $\quad 30$

Overbreak

Feeler holes, ground water, grouting, supports, and progress

Concrete lining

Stations $291+60$ to $343+00$

Metamorphosed Mesozoic Sedimentary Rocks

Geology

Petrography

Structure

Engineering practices in relation to geology .......................... 40

Overbreak

Feeler holes, ground water, grouting, supports, and progress

Stations $343+00$ to $690+00$

Montezuma Quartz Monzonite Stock

Geology

Rock units

Precambrian rocks .

Montezuma Quartz Monzonite

Petrography

Structural geology

Faults, veins, and joints ...................................... 47

Ore mineralization and wallrock alteration .................. 51

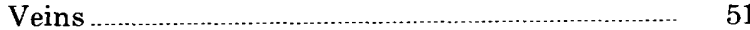

Mineralogy ......................................................... 51

Wallrock alteration

Engineering practices in relation to geology ........................ 53

Overbreak

Feeler holes, ground water, grouting, supports, and progress

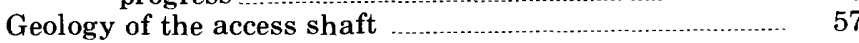

References cited 


\title{
ILLUSTRATIONS
}

\author{
[Plates are in pocket]
}

Plate 1. Geologic plans and sections, equal-area plots of structural data, and engineering data for the Roberts Tunnel from station $0+00$ to station $694+57$.

2-5. Composite tunnel sections and geologic plans and sections of selected intervals showing relation between overbreak and geology in the Roberts Tunnel:

2. Between stations $12+46$ and $69+56$.

3. Between stations $84+16$ and $174+66$.

4. Between stations $186+46$ and $331+40$.

5. Between stations $353+00$ and $688+40$.

6-11. Detailed geologic plans and sections, and engineering data, for selected intervals of the Roberts Tunnel:

6. Stations $21+00$ to $28+50$ and stations $34+50$ to $42+00$.

7. Stations $47+00$ to $54+50$, stations $97+50$ to $105+00$, and stations $172+50$ to $180+00$.

8. Stations $180+00$ to $187+50$, stations $200+00$ to $207+50$, stations $215+00$ to $222+50$, and stations $240+00$ to $247+50$.

9. Stations $270+00$ to $277+50$, stations $285+00$ to $292+50$, stations $297+50$ to $305+00$, stations $305+00$ to $312+50$, and stations $333+00$ to $340+50$.

10. Stations $354+00$ to $361+50$, stations $424+50$ to $432+50$, stations $442+00$ to $449+50$, and stations $502+50$ to $510+00$.

11. Stations $527+50$ to $535+00$, stations $632+50$ to $640+00$, stations $655+00$ to $662+50$, and stations $685+00$ to $692+50$.

FIgURE 1. Index map showing location of Harold D. Roberts Tunnel

2. Generalized geologic section of the Harold D. Roberts Tunnel

3. Photograph of West Portal inlet channel excavation

4. Generalized columnar section of the sedimentary rocks

5-9. Photographs of sedimentary rock structures:

5. Jointed mudstone in the Morrison Formation

6. Middle unit of the Dakota Group

7. Benton Shale, felsite porphyry sill, and Dakota Group at emergency gate shaft

8. Folded shaly limestone in Smoky Hill Marl Member of Niobrara Formation

9. Sheared black sandy shale of the Pierre Shale

10. Equal-area plot of faults between stations $9+46$ and $180+00$

11. Diagrams showing typical average attitudes of bedding, faults, and joints between stations $9+46$ and $180+00$

12. Diagram showing blasthole patterns and tunnel configuration

13. Photographs showing special operations in sedimentary rocks of the Dakota Group

14. Geologic section of the emergency gate shaft, station $14+40$

15. Photomicrographs of mylonites...

16. Photograph showing right rib and face near station $180+00$ showing mixture of sheared, altered gneiss and Pierre Shale in a steep fault that intersects the Williams Range thrust fault

17. Equal area plots and histogram showing compilations of fault data for Roberts Tunnel, from West Portal to station $468+19$

18. Diagrammatic sections showing stages in the development of the Williams Range thrust fault and associated features

19. Engineering drawing showing dimensions of "old" and "new" 6-inch steel sets

20. Photographs showing support problems

21-26. Photomicrographs of metamorphosed and unmetamorphosed sedimentary rocks:

21. Metamorphosed sandstone in baked shale sequence

22. Unmetamorphosed sandstone from Pierre Shale

23. Cordierite crystals in fine-grained hornfels formed from Pierre Shale

24. Sheared baked shales

25. Cordierite metacrysts in fine-grained hornfels

26. Altered cordierite crystals in a hornfels inclusion in quartz monzonite

27. Photographs of highly jointed baked shale and of water issuing from exploratory holes penetrating fault zone in baked shale in Roberts Tunnel... 
FIGURE 28. Diagram showing average attitudes of planar features between stations $291+60$ and $343+00$

29. Photomicrographs of Montezuma Quartz Monzonite

30. Photomicrographs of aplite from Montezuma Quartz Monzonite....

31-38. Diagrams showing statistical relationships of tunnel and fractures in quartz monzonite:

31. Between stations $343+$ and $384+83$

32. Between stations $384+83$ and $426+66$

33. Between stations $426+66$ to $468+49$

34. Between stations $468+49$ and $500+00$

35. Between stations $500+00$ and $550+00$

36. Between stations $550+00$ and $600+00$

37. Between stations $600+00$ and $650+00$

38. Between stations $650+00$ and $690+00$

39. Equal-area plot of fault, vein, and joint maxima

40. Contoured equal-area plot of poles of 394 veins between stations $460+00$ and $800+00$

41. Paragenetic diagrams of quartz-sulfide and rhodochrosite-sphalerite-anhydrite veins

42-44. Photographs of Montezuma Quartz Monzonite:

42. Altered, squeezing quartz monzonite at station $428+25$

43. Altered, squeezing quartz monzonite near station $500+00$

44. Massive quartz monzonite in heading at station $458+46$

45. Geologic section of access shaft parallel to tunnel tangent......

46. Photograph of veined and altered Montezuma Quartz Monzonite in access shaft

\section{TABLES}

TABLE 1. Overbreak in tunnel sections, stations $0+00$ to $180+00$

2. Mineral composition of gouge and altered wallrocks between stations $180+00$ and $291+60$

3. Average modes of Montezuma Quartz Monzonite and aplite $\ldots$

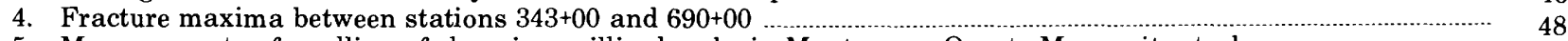

5. Measurements of swelling of clays in argillized rocks in Montezuma Quartz Monzonite stock …..........................

\section{GLOSSARY}

"A" line. The line within which no steel support or timber support shall remain.

Arch. Curved roof of an underground opening. The part of the tunnel above the centerline.

Arching tendency. Tendency of incompetent or moderately competent rocks to form an arch above an underground opening by caving. Commonly, the arch assumes the shape of a Gothic arch in cross section.

"B" line. The line within which no unexcavated material, tamped fill, lagging, spiling, crown bars, spreaders, collar braces, or wall plates shall remain.

Bid items. Items of work listed in contract documents and serving as the basis for bids by the contractor.

Blocking. Wood blocks placed between steel supports and walls or arch of tunnel to provide support and maintain alinement of ribs.

Breast boards. Wood planking placed temporarily at tunnel heading to contain incompetent rock.

California switch. A section of movable double track permitting switching of muck cars near the tunnel heading.
Centerline. The line (in the Roberts Tunnel) at the center of the finished concrete lining of circular cross section.

Change order. Order issued to define procedures or items of work not covered in original contract documents, or order to change the provisions expressed in the original contract documents.

Collar brace. Wood or steel brace placed between or on top of sides of steel or timber sets to maintain alinement. Also called a "spreader."

Competent rock. Rock that stands without support in underground openings.

Contract drawings. Drawings included in the contract documents.

Contract specifications. Specifications for various items of construction included in the contract documents.

Crownbar. Steel rail or heavy wood plank placed on top of steel set or sets nearest heading and projecting forward to tunnel heading. Provides temporary support of rocks in arch until additional steel sets and lagging can be installed closer to the heading.

Extra work order. Order issued to contractor to perform work not originally described in the contract documents. 
False set. A steel or timber set placed temporarily to expedite a tunneling operation; for example, a spiling operation.

Feeler hole. Hole drilled from tunnel heading or elsewhere to test geologic conditions beyond heading or in rocks adjacent to an underground opening.

Footblock. Wood block serving as a support at the base of a steel rib. Block on which ribs are erected.

Grout. Mixture of cement, water, and, for special purposes, various additives. Pumped into fractured rock to fill voids, seal off water flows, and increase strength.

Gunite. Mixture of water, sand, and cement sprayed on exposed rock to provide a protective coating.

Heading. The working face at the limit of penetration of the tunnel.

Heavy ground. Ground that requires full support. Typical highly faulted and altered rock associated with intensive faulting.

Heavy rock. Rock that is intensly faulted and altered and requires full support in underground openings.

Illite. A polymorphic form of muscovite that has a two layered (2M) monoclinic form. Identified by X-ray diffraction.

Incompetent rock. Rock that will not stand in underground openings without support.

Invert. The portion of the tunnel below the centerline. The bottom or floor of a tunnel.

Invert section. The section of the tunnel below the centerline or spring line.

Invert strut. Steel or wood support across invert, or bottom of tunnel, to hold foot of legs in place or to prevent heaving of floor.

Jumbo. A movable platform on which one or more drills are mounted. Used primarily for drilling blast holes at the tunnel heading but may provide elevated work space for other operations.

Jump set. Steel or timber set placed between existing sets to provide additional support.

Lagging. Steel plates or beams or wood planking placed above and on sides of steel ribs to contain broken rock and to prevent its fall into an underground opening. Also acts to receive and transfer rock loads to ribs, after appropriate blocking. Spacing depends on local conditions.

Left rib. The steel rib on the left side of the tunnel as one faces the tunnel heading.

Liner plate. Preformed plain or corrugated steel plates placed behind or between ribs as tight lagging to contain bad ground, to divert water flows, and to distribute rock loads evenly to ribs.

Muck. Disaggregated rock formed by blasting operation or by the free flow of incompetent material into an underground opening.

Mucking machine. The machine used to load broken rock for haulage out of underground excavations.

Overbreak. Rock removed from outside the payline as defined in the specifications. Usually expressed as the percentage of material removed in a cross-sectional area relative to the area within the payline. Also may be expressed as a volume percent.

Payline. The line beyond which the contractor shall not be paid for excavation. Excavation outside the payline is done at the contractor's expense.

Permanent support. The concrete lining of the tunnel. Steel and timber supports are regarded as temporary supports.
Popping rock. Stressed rock that fails with explosive violence and ejects large and small rock fragments at high velocity.

Pressure tunnel. A tunnel with control works at the outlet and designed to withstand, without loss or structural failure of the tunnel, water stored in the tunnel under hydrostatic head. In the Roberts Tunnel, with the outlet valves closed and Dillon Reservoir filled to capacity, the hydrostatic pressure in the tunnel near the surge-chamber shaft is equivalent to that of a standing column of water about 360 feet in height-that is, about 156 psi.

Progress. A measure of the speed and efficiency with which construction of any kind proceeds.

Progress report. In the Roberts Tunnel operation, progress was reported twice each month. The report periods extended from the first to the fifteenth and from the fifteenth to the last day of each month.

Raveling. Ground that breaks into small pieces when drilled and tends to cave or slough into tunnel.

Rib. A curved steel segment comprising half of a steel set or support.

Right rib. The steel rib on the right side of the tunnel as one faces the tunnel heading.

Roof. The upper part of a tunnel, especially that part of the tunnel immediately above the centerline.

Rock bolt. Steel bolt that is split at one end and inserted into drilled hole in rock to support the rock. Head of bolt is forced against a steel plate next to the rock to make bolting action more effective.

Running ground. Clayey or sandy aggregate, usually watersaturated, that flows freely into underground excavations.

Spalling rock. A rock mass under stress that yields thin slabs or wedges of rock by rapid failure. Slabs commonly form parallel to walls or to arch of an opening in rock.

Spiling. Pointed steel bars or rails, or wood planks or logs driven into the tunnel heading to support incompetent rock until supports can be placed. Usually, the spiling is driven above and beyond the supports nearest the heading, or on top of and beyond a false set.

Spitting rock. A rock mass under stress that breaks and ejects small fragments with considerable velocity.

Spreader. Wood plank or steel beam placed between ribs to maintain tension on tie rods or preserve alinement. Also called "collar brace."

Spring line. The line across or parallel to the tunnel, above which the steel ribs are bent to a radius of curvature different from that below it. Longest horizontal dimension between steel ribs. May or may not coincide with centerline.

Squeezing ground. Incompetent material, generally clayey, that behaves plastically under stress and tends to close the tunnel opening because of adjacent-or superjacent loads.

Station. Distance from zero point measured in hundreds and fractions of feet. For example, station $105+06.5$ is $10,506.5$ feet from station $0+00$.

Steel rib. One of the segments of bent structural steel bolted to another rib to form a steel support or steel set in the tunnel.

Steel set. Steel support consisting of two ribs bolted or welded together. May include a strut across the invert of the tunnel. 
Strut. Sometimes called "invert struts" are steel or timber segments placed between steel ribs across tunnel invert to provide additional strength. Bolted, welded, or otherwise fastened to bottom extensions of ribs.

Support. Any fabricated structure, steel, wood, or concrete, placed to prevent failure of rocks around underground openings.

Swelling ground. Rock that swells after being exposed. Usually increases in volume because of hydration of clay minerals in an altered rock.

Temporary support. Support placed to support tunnel rocks until permanent supports can be installed. All supports except the concrete are generally regarded as temporary.

Tie rod. Steel rod threaded at both ends. Used as a connection between adjacent steel sets to hold sets in place and provide strength in the direction of the tunnel.

Timber lagging. Timber planks placed on sides and on top of steel or timber sets to contain exposed rocks between the sets and to transmit loads to the steel sets.
Top heading. A small tunnel opening ahead of the full-size opening. Used to probe and place temporary supports in exceedingly incompetent or wet sections of tunnel.

Tunnel face. The tunnel heading.

Tunnel section. Outlines of tunnel as measured at right angles to centerline. Also, any portion of the tunnel measured parallel to direction of the tunnel.

Tunnel supports. Wood, steel, or concrete structures placed to prevent collapse or failure of tunnel rocks.

Wall plate. Steel or timber beams of various designs placed longitudinally along sides of tunnel to act as a level support for ribs. Commonly, the wall plate serves to transmit loads from the ribs to blocks or posts with a spacing different from that of the ribs and distributes loads on ribs through the intervals between ribs.

Wedge. Wood wedge used to hold lagging or steel supports in place.

Working face. The heading being excavated by drilling and blasting. 


\title{
GEOLOGY OF THE WESTERN PART OF THE HAROLD D. ROBERTS TUNNEL, COLORADO (STATIONS 0+00 to $690+00$ )
}

\author{
By Ernest E. Wahlstrom, Charles S. Robinson, and V. Quentin Hornback
}

\section{ABSTRACT}

The geology of the western part of the Harold D. Roberts Tunnel (stations $0+00$ to $690+00$ ) at tunnel level can be divided into four geologic provinces, which directly influenced the engineering practices in the construction of the tunnel. The descriptions of the engineering geology and the engineering practices are discussed in four sections corresponding to the different geologic provinces. The Roberts Tunnel between stations $0+00$ and $180+00$ was driven chiefly through sedimentary rocks of Mesozoic age. West of the West Portal (station 9+46), the approach is an opencut in thick stream deposits. From the portal eastward, the succession of sedimentary rocks, from oldest to youngest, are the Entrada(?) Sandstone and Morrison Formation of late Jurassic age; the Dakota Group of Early Cretaceous age; the Benton Shale of Early and Late Cretaceous age; and the Niobrara Formation and Pierre Shale of late Cretaceous age. Below the Entrada(?) Sandstone, west of the tunnel portal, the Maroon Formation of Pennsylvanian and Permian age and the Lykins Formation of Permian and Triassic(?) age are exposed. The only nonsedimentary rock exposed in the tunnel in this interval is a dike of intrusive breccia having a matrix of devitrified felsite.

The dominant geologic structure in the vicinity of the West Portal of the tunnel is the Williams Range thrust fault, along which Precambrian igneous and metamorphic units have been superimposed on the Pierre Shale. The sedimentary rocks beneath the fault generally strike and dip in the same direction as the fault, but, locally, steep faults and minor folds cause sharp departures from the regional strike and dip of the sedimentary rocks. Structural analyses indicate that the prominent fractures fall into two groups: one that strikes northwest parallel to the axis of the Front Range and parallel to the Williams Range thrust fault, and another that strikes northeast nearly parallel to the Front Range mineral belt.

Engineering practices used during construction of the tunnel were related to requirements imposed by the geology. The amount of overbreak and the shape of the tunnel, the support requirements, the amount of ground water, the use of feeler holes and grouting, and the progress were dependent upon such geologic factors as the apparent angle of dip and the fissility of the bedding, the spacing and orientation of joints, and, in sheared rock, the presence of gouge in or along faults.

The Roberts Tunnel between stations $180+00$ and $291+60$ is in the thrust plate of the Williams Range thrust fault. The rock units intersected by this section of the tunnel are chiefly aplite, pegmatite, biotite gneiss, hornblende gneiss, and quartzite, which are all Precambrian age, and which have been complexly sheared and altered. Locally, units of breccia and mylonite were formed as a result of the shearing and alteration. A flat-lying dike of felsite porphyry, of Tertiary age, was also intersected by the tunnel.

The principal structural feature of this section of the tunnel is the Williams Range thrust fault, which is intersected twice by the tunnel. The thrust fault and the rock units of the thrust plate are cut by high-angle faults. In general, the high-angle faults do not parallel the Williams Range thrust fault; some may be tear faults formed at the time of thrusting, but many are younger. An evaluation of the fault data suggests that the high-angle faults were formed parallel to the axis of the Front Range and to the Front Range mineral belt. The analysis also suggests that the Williams Range thrust developed by gravity sliding as a result of essentially vertical uplift of the Front Range (northeast dipping), and that the westward-dipping segment of thrust was the result of later uplift of the fault by the intrusion of the Montezuma stock.

Tunneling through the shattered, altered, water-saturated rocks in the thrust plate above the fault was by far the most difficult work involved in any section of the tunnel. Maximum use of steel and timber supports and extensive, time-consuming grouting operations greatly reduced the rate of advance of the tunnel headings as compared to the rate of advance of the headings in other parts of the tunnel. Steel and timber supports were required to provide temporary support for the interval, and in no sections of this portion of the tunnel were the rocks competent enough to stand without support.

The section of the Roberts Tunnel between stations 291+60 and $343+00$ is bounded geologically by the Williams Range thrust fault on the west and the Montezuma stock on the east. The rocks in this section are partially to highly metamorphosed shale, siltstone, sandstone, limy shale, and limestone of the Pierre Shale and probably of the Niobrara Formation and Benton Shale. The effects of metamorphism increase-shown by the change in mineral composition-as proximity to the Montezuma stock increases.

The brittle rocks of this interval of the tunnel are closely faulted and jointed. Many of the strong joints strike N. $55^{\circ} \mathrm{W}$. and dip steeply north; whereas the faults commonly strike N. $10^{\circ} \mathrm{E}$. and dip about $35^{\circ} \mathrm{W}$. about parallel to the eastern exposure of the Williams Range thrust fault. Steep faults parallel in attitude those in the thrust plate to the west and those in the Montezuma stock to 
the east. The faulting and jointing occurred prior to and contemporaneously with the formation of the Williams Range thrust fault and after the intrusion of the Montezuma stock.

Engineering practices were dependent principally on conditions involving a multitude of intersecting fractures in highly brittle rock. Overbreak was especially large in and near the faults that were accompanied by intricate joint patterns or in fault zones that contained crushed gougy materials and water. Steel supports were required for 97.7 percent of this interval of the tunnel, and feeler holes were used in advance of the heading for the entire interval. Tunnel progress, in general, was satisfactory. The poor progress resulted from the necessity to halt advance of the tunnel heading in order to grout heavy waterflows intercepted in feeler holes, especially at station $339+50$ where 23,435 sacks of cement were used to seal off ground-water flows in a 90-foot-wide intensely fractured zone.

The Roberts Tunnel between stations $343+00$ and $690+00$ was driven chiefly through the Montezuma Quartz Monzonite stock. Between stations $625+00$ and $636+85$, the tunnel was driven through Precambrian rocks, which consist chiefly of a variety of biotite gneisses and pegmatite and which are considered to form a roof pendant in the stock. The stock is cut by faults and joints, some of which are mineralized to form veins. The chief sulfide minerals in the veins are pyrite, sphalerite, chalcopyrite, and galena. The chief gangue minerals are quartz, dolomite, anhydrite, gypsum, and rhodochrosite. None of the veins contained economic deposits of ore minerals. The wallrock of the veins was extensively altered locally.

Attitude and frequency of fractures and alteration were the chief geologic features that determined the engineering practices between stations $343+00$ and $690+00$. The a mount of overbreak, the need for feeler holes to detect ground water and incompetent rock-and, if found, the need to grout-the support requirements, and the rate of progress were directly related to these geologic features. Of particular importance to the support requirements and the rate of progress was the local alteration of the rock to the clays that contained montmorillonite. In these sections, the montmorillonite absorbed moisture and exerted extreme pressures on the support, which then required the addition of more support and slowed the progress at the heading.

The engineering geology and engineering practices in the western part of the Harold D. Roberts Tunnel (stations $0+00$ to $690+00$ ) illustrate the complexity of the geology in the Front Range of Colorado, as well as the engineering requirements in the design and construction of tunnels in a complex geologic environment.

\section{INTRODUCTION}

Chapter $\mathrm{C}$ of this report on the engineering geology of the Harold D. Roberts Tunnel describes the geology at tunnel level for the approximate west half of the tunnel. The geology is discussed in four sections, each describing the geology of a different geologic province from the West Portal eastward. The first section describes the engineering geology of the tunnel in Mesozoic sedimentary rocks west of the Williams Range thrust fault; the second section, in the Precambrian rocks of the Williams Range thrust plate; the third section, in the metamorphosed Mesozoic sedimentary rocks east of the Williams Range thrust fault; and the fourth section, in the
Tertiary Montezuma Quartz Monzonite stock. The reader is referred to Chapter $\mathrm{A}$ (Wahlstrom, 1974) for the history of the location of the tunnel and the geologic work leading to excavation of the tunnel and to Chapter B (Robinson, Warner, and Wahlstrom, 1974) for a detailed description of the general geology of the tunnel area. Chapter D (Warner and Robinson, 1981) describes the engineering geology of the east half of the tunnel, which is in Precambrian igneous and metasedimentary rocks. A summary of the engineering geology of the entire tunnel is contained in chapter $\mathrm{E}$ (Wahlstrom, 1981).

Chapter C was prepared by Ernest E. Wahlstrom, assisted by Charles S. Robinson. The geologic mapping of this section of the tunnel was done by $\mathrm{V}$. Quentin Hornback under the direction of E. E. Wahlstrom. V. Q. Hornback assisted in the compilation of the geologic and engineering data, and in the preparation of illustrations.

The Roberts Tunnel was constructed to divert water from the Blue River near Dillon, Colo., on the western slope of the Continental Divide, to the North Fork of the South Platte River near Grant, Colo., on the eastern slope of the Continental Divide, a distance of 23.3 miles (fig. 1). this water is used for domestic and industrial purposes by the City and County of Denver.

The Roberts Tunnel transects a geologically complex area of the Front Range of the Colorado Rocky Mountains (fig. 2). The area includes Precambrian igneous and metasedimentary rocks, Mesozoic sedimentary rocks, and Tertiary igneous rocks. A complex structural history includes folding and faulting during Precambrian time and during the Laramide orogeny.

The Precambrian rocks, which compose about twothirds of the area penetrated by the tunnel, consist of a sequence of metasedimentary rocks that were intruded by igneous rocks. The Precambrian rocks occur in the east half of the tunnel and in the Williams Range thrust plate (fig. 2). The metasedimentary rocks consist of interlayered biotite-quartzplagioclase gneiss and schist, hornblende-plagioclase gneiss, biotite-quartz-microcline gneiss, amphibolite, calc-silicate rocks, and quartzite. The igneous rocks include dikes and irregularly shaped plutons similar in mineral composition, structure, and relative age to the Boulder Creek Granite and the Silver Plume Granite. Pegmatite and aplite dikes, probably related to the Precambrian granitic rocks, occur locally. The Precambrian rocks of the Williams Range thrust plate have been extensively sheared and altered, and their characteristics are difficult to determine. 


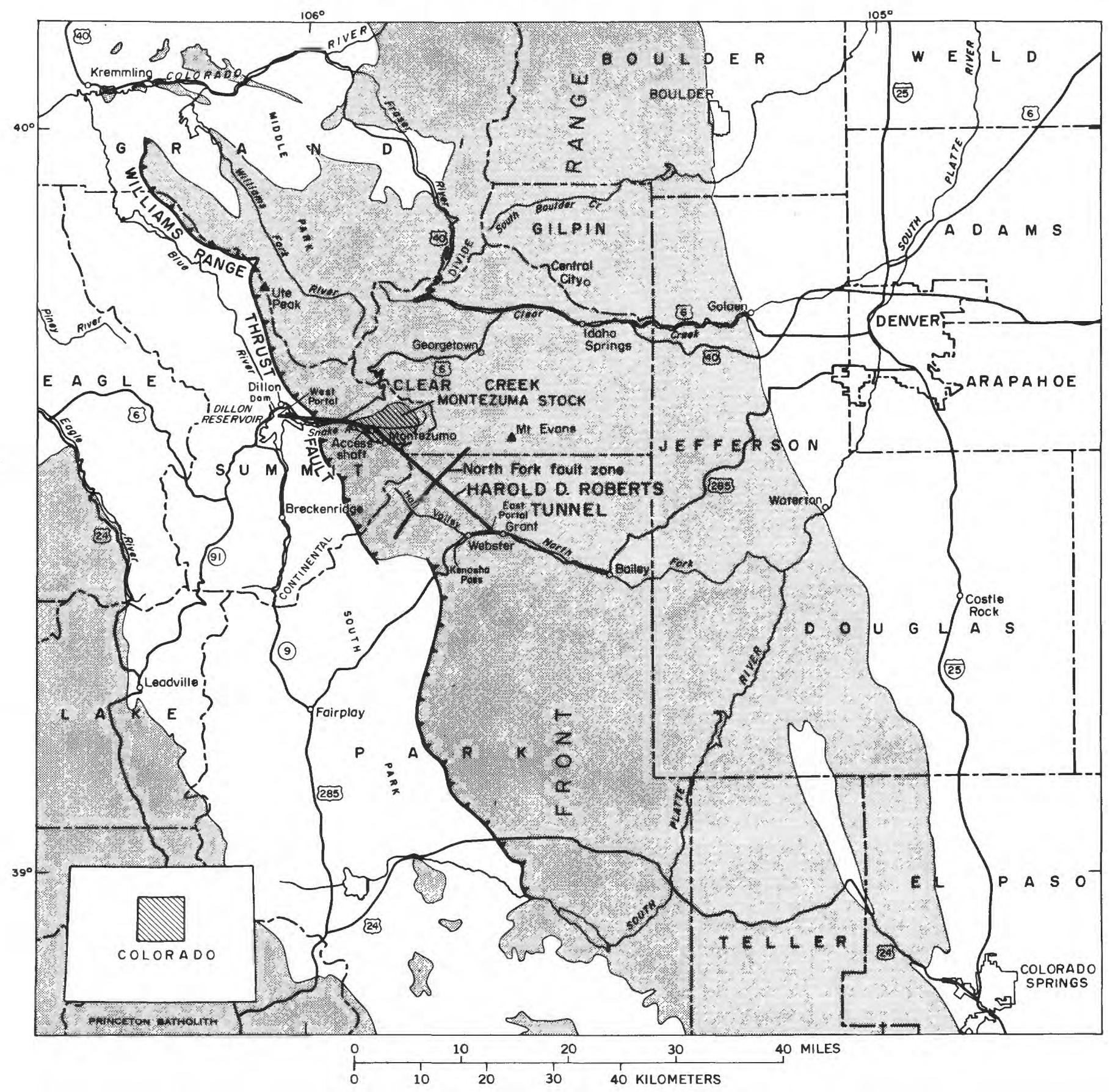

EXPLANATION

Crystalline rocks

Sedimentary rocks

FIGURE 1.-Location of Harold D. Roberts Tunnel.

Sedimentary rocks of Mesozoic age are exposed along the west one-fourth of the tunnel (fig. 2). These include the Entrada(?) Sandstone and Morrison
Formation of Late Jurassic age, the Dakota Group of Early Cretaceous age, the Benton Shale of Early and Late Cretaceous age, and the Niobrara Formation 


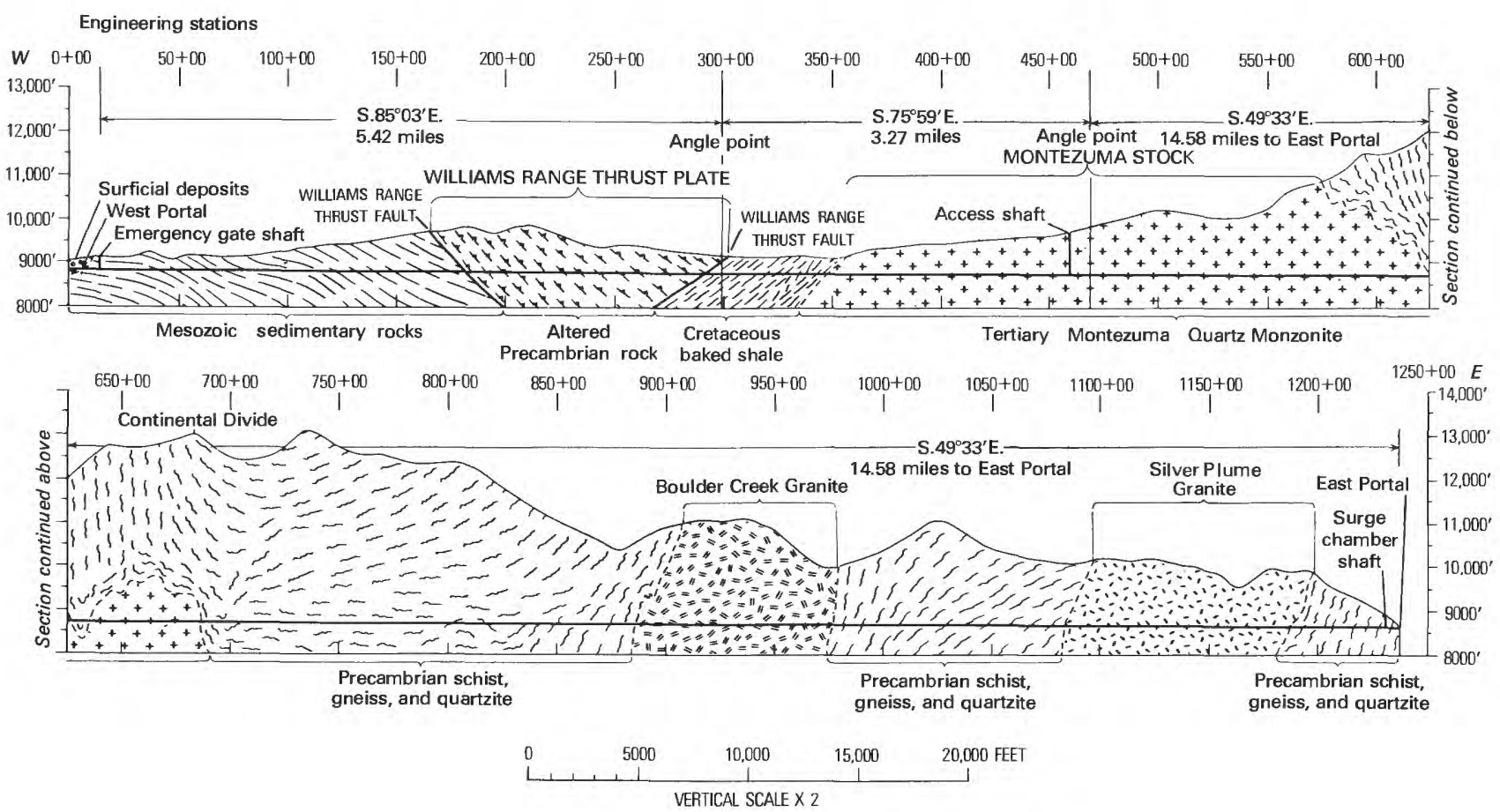

Figure 2.-Generalized geologic section of the Harold D. Roberts Tunnel. Geology from maps prepared for Tipton and Kalmbach Inc. by E. E. Wahlstrom, L. A. Warner, and Quentin Hornback. Published with permission of the Board of Water Commissioners, City and County of Denver.

and Pierre Shale of Late Cretaceous age. Underlying the sedimentary rocks exposed in the tunnel, and exposed to the west of the tunnel and intersected by drill holes along the tunnel line, are the Maroon Formation of Pennsylvanian and Permian age and the Lykins Formation of Permian and Triassic(?) age. The sedimentary rocks west of the Williams Range thrust plate dip eastward toward the axis of the Front Range.

Early during the Laramide Revolution, the Williams Range thrust fault developed. Along this thrust Precambrian rocks were superimposed on the Pierre Shale. Following this period of thrusting, the Montezuma Quartz Monzonite stock was intruded. The tunnel transects about 4.5 miles of the Montezuma stock (fig. 2). As a result of the intrusion of the stock, the Williams Range thrust fault was folded upward. The tunnel intersects the fault plane at two points. Between the eastern exposure of the thrust and the Montezuma stock is a sequence of shale and siltstone that is metamorphosed to hornfels in proximity to the stock. This sequence of shale and siltstone is believed to be equivalent for the most part to part of the Pierre Shale to the west of the Williams Range thrust.

Before and after the intrusion of the Montezuma stock, a series of dikes were emplaced in the Precambrian units that now surround the stock. The oldest of these dikes consist of augite or hornblende diorite. The dikes are contemporaneous in age and younger than the stock and are latite and rhyolite porphyry.

The structural features of the Front Range were developed chiefly during Precambrian time and the Laramide orogeny. During Precambrian time, the Precambrian sedimentary rocks were metamorphosed and plastically deformed, intruded by igneous rocks, and cataclastically deformed. During the Laramide deformation, the Front Range was uplifted, the Williams Range thrust fault occurred, and the Front Range mineral belt was formed. The mineral belt is a northeast-trending zone of faults, veins (with associated alteration), and igneous intrusions, which extend diagonally to the southwest across the Front Range. The structural development of the mineral belt was in part controlled by preexisting Precambrian structural features. 


\section{Station $0+00$ to $180+00$ Sedimentary Rocks}

\section{GEOLOGY}

The approach to the West Portal of the Roberts Tunnel (sta. 9+46) is an opencut excavated in deep stream gravels, which cover the floor of the Blue River valley (pl. 1, stas. $0+00$ to 9+46). The West Portal is in mudstone of the Morrison Formation, just below the lower quartzite of the Dakota Group (fig. 3). From the West Portal to station $46+40$ (pl. 1), the tunnel passes through a succession of faults that have brought rocks of the Dakota Group, the Morrison Formation, and the Entrada(?) Sandstone to tunnel elevation and into fault contact with each other. East of station $46+40$, as far as station $180+00$, the tunnel intersects a thick succession of marine limestones, shaly limestones, limy shales, shales, sandy and silty shales, siltstones and shaly siltstones, and sandstones of the Benton Shale, the Niobrara Formation, and the Pierre Shale. The only nonsedimentary rock is a dike of intrusive breccia at station $125+40$, containing rounded to angular sedimentary rock fragments in a devitrified felsitic matrix. Near station $180+00$ the sedimentary rocks are intersected by the Williams Range thrust fault, a

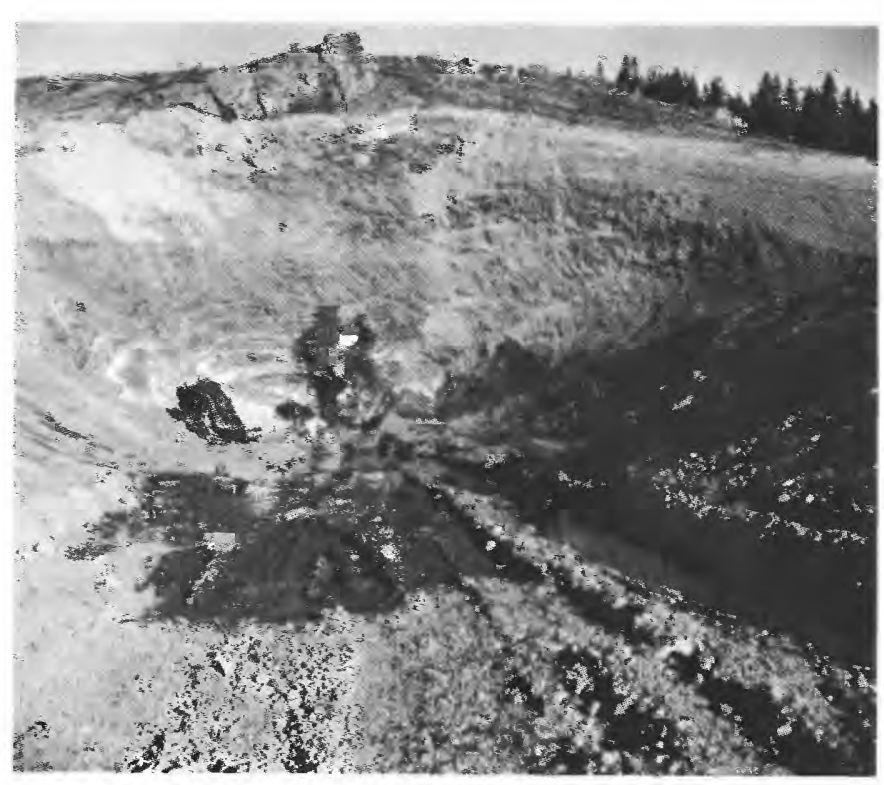

FIGURE 3.-West Portal inlet channel excavation. Ridge beyond excavation is capped by quartzite of Dakota Group. October 15, 1956. major northeast-dipping fault that resulted in superposition of Precambrian igneous and metasedimentary rocks on Pierre Shale of Late Cretaceous age (pl. 1).

\section{ROCK UNITS \\ SEDIMENTARY ROCKS}

The oldest sedimentary rocks encountered in the Roberts Tunnel are the aeolian sandstones of the Entrada(?) Sandstone and the youngest rocks are sandy shales of the middle part of the Pierre Shale. Sedimentary rocks older than the Entrada(?) Sandstone were penetrated in exploratory drill holes and in excavations for the Dillon Dam, about 1 mile northwest of the West Portal of the Roberts Tunnel, and the sequence includes siltstones and sandstones of the Lykins Formation and arkoses of the Maroon Formation. A brief description of these units is included in this report, although they were not exposed in the tunnel. A generalized columnar section of the sedimentary rocks is presented in figure 4.

\section{MAROON FORMATION}

The Maroon Formation, of Pennsylvanian and Permian age, lies below the elevation of the tunnel and was not observed during construction, but it was penetrated to a depth of 110 feet in an exploratory drill hole in the foundation of the Dillon Dam below the gravels of the Blue River valley (fig. 1), about 1 mile north of the old townsite of Dillon (now under water of Dillon Reservoir). Cores consist of pink and light-gray arkose and conglomeratic arkose and quartzose sandstone, which contains angular to subangular clastic grains of quartz, feldspar, and quartzose-feldspathic rock fragments. Hematite in the matrix and some feldspar fragments contribute to the pink color of some layers. A few thin layers of red sandy siltstone, which is rich in mica, alternate with arkose and sandstone layers.

\section{LYKINS FORMATION}

The Lykins Formation was not observed in the Roberts Tunnel; a complete section was exposed in the diversion tunnel in the west abutment of the 


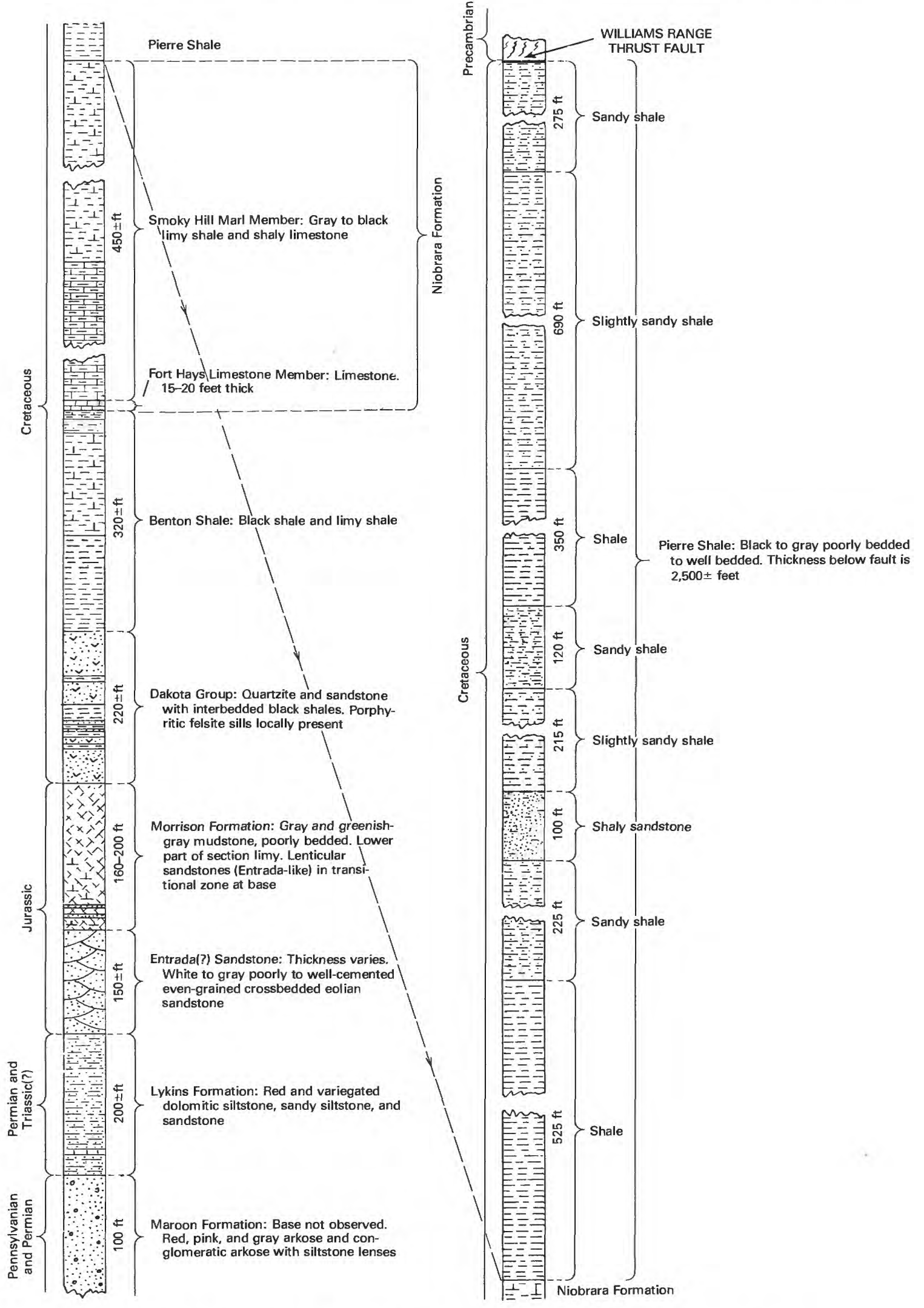

FIGURE 4.-Generalized columnar section of the sedimentary rocks, Roberts Tunnel. 
Dillon Dam. The Lykins Formation, of Permian and Triassic(?) age, is about 200 feet thick and consists of a succession of red to pink lenticular siltstones, sandy siltstones, silty sandstones, and thin siliceous limestones and dolomites. A study of thin sections reveals small dolomite crystals in siltstones and sandstones in the lower part.

\section{ENTRADA (?) SANDSTONE}

The Entrada(?), an eolian sandstone of Late Jurassic age, was first penetrated by the tunnel at station $27+20$, where it is in fault contact with mudstones of the Morrison Formation. The sandstone extends to station $30+00$ in the tunnel and was again penetrated between stations $32+80$ and $33+70$. Only the upper part of the formation was observed, but complete sections were recovered from core drill holes and surface exposures in the vicinity of the West Portal of the tunnel. The formation is lenticular, and the thickness varies laterally from a few feet to as much as 150 feet in exposures or drill holes less than 1 mile apart. Lenticular layers of Entrada-like sandstone as much as 15 feet thick are present in the basal part of the overlying Morrison Formation, and, in some exposures, the contact between the two formations is gradational.

Sandstones of the Entrada are white to gray, firmly to poorly cemented, and conspicuously crossbedded. Well-rounded, uniformly sized, frosted quartz grains are embedded in a matrix of clay minerals or, in firmly cemented varieties, in a cement of silica with minor amounts of carbonates and clay minerals.

MORRISON FORMATION

The Morrison Formation, of Late Jurassic age, is $160-200$ feet thick in the vicinity of the West Portal and consists of a succession of poorly to well bedded mudstones (fig. 5), calcareous mudstones, and several thin layers of dense lithographic limestone. The tunnel intersected beds near and at the top of the formation in several intervals between stations $9+70$ and $27+20$ and passed through the basal part of the formation between stations $30+20$ and $38+50$. A 5 -foot layer of Dakota-like quartzite is locally present about 10 feet below the upper contact of the formation with the base of the Dakota Group.

The calcareous mudstones in the lower part of the formation are more conspicuously bedded than the noncalcareous rocks in the upper part. All the mudstone layers are very fine grained and, as seen under the microscope, contain a considerable

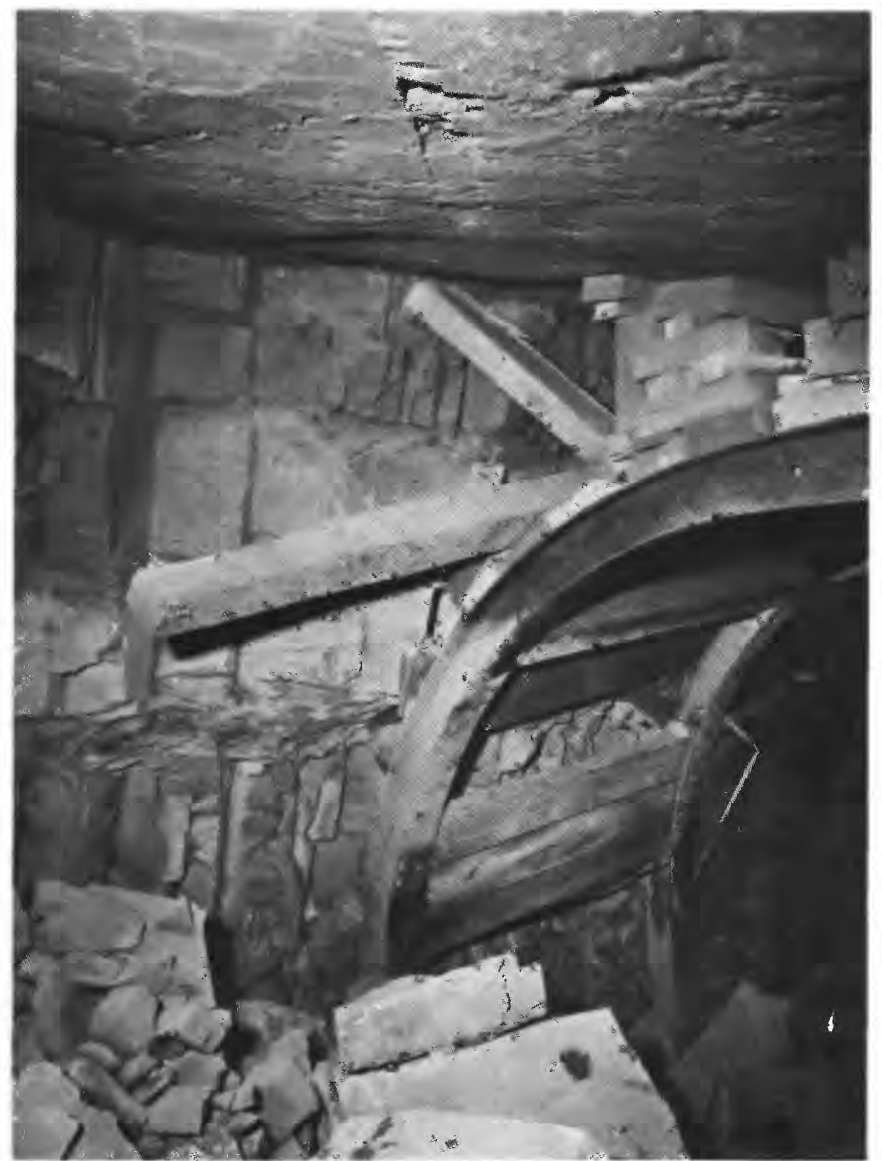

FIGURE 5.-Jointed mudstone in the Morrison Formation at station 10+35, Roberts Tunnel.

proportion of amorphous or nearly amorphous materials. Many layers are brittle and break with a subconchoidal to conchoidal fracture. X-ray diffractometer patterns of the calcareous mudstones indicate the presence of abundant quartz and calcite. Crystallized clay minerals were not present in sufficient amounts to produce any indication of their presence on diffractometer tracings, even at maximum settings for sensitivity of the diffractometer. Clay components, if present, must be amorphous.

Beds of massive to poorly bedded noncalcareous mudstone in the upper part of the formation tended to break down into sticky mud when they came into contact with water in the tunnel. Some layers swelled in the presence of moist tunnel air and slowly slacked from the walls and arch of the tunnel. Diffractometer tracings indicated the presence of very abundant quartz and minor amounts of clay minerals, especially "illite," kaolinite, and montmorillonite. A sample of swelling mudstone contained a small 
amount of montmorillonite, the presence of which probably accounted for the tendency of the mudstone to expand on contact with water.

\section{DAKOTA GROUP}

Rocks of the Dakota Group, as exposed in the Roberts Tunnel, are similar in fabric and lithology to Dakota Group rocks in many other parts of Colorado. The rocks are of Early Cretaceous age and comprise a section about 220 feet thick of intercalated lenticular sandstones, sedimentary quartzites, and black siliceous shales. The group can be subdivided into three units on the basis of lithology. The basal unit is nearly massive sandstone and quartzite and has a few thin black shale partings. A middle unit consists of moderately well bedded, brittle, black shale beds and several lenticular sandstone beds from a few inches to a few feet in thickness (fig. 6). The upper unit, which makes up from a third to a half of the total thickness, is nearly massive to well bedded quartzite and has a few, thin, highly lenticular black shale beds. The quartzites in some beds are crossbedded.

The quartzites are very hard and brittle and are highly quartzose. The rounded quartz grains are firmly embedded in a siliceous cement. In a few tunnel exposures, stylolites have formed by irregular dissolution along bedding planes. Many exposures of the beds of quartzite and sandstone are conspicuously fractured and are transected by numerous joints at, or nearly at, right angles to the bedding.

Sills of felsite porphyry are present in many

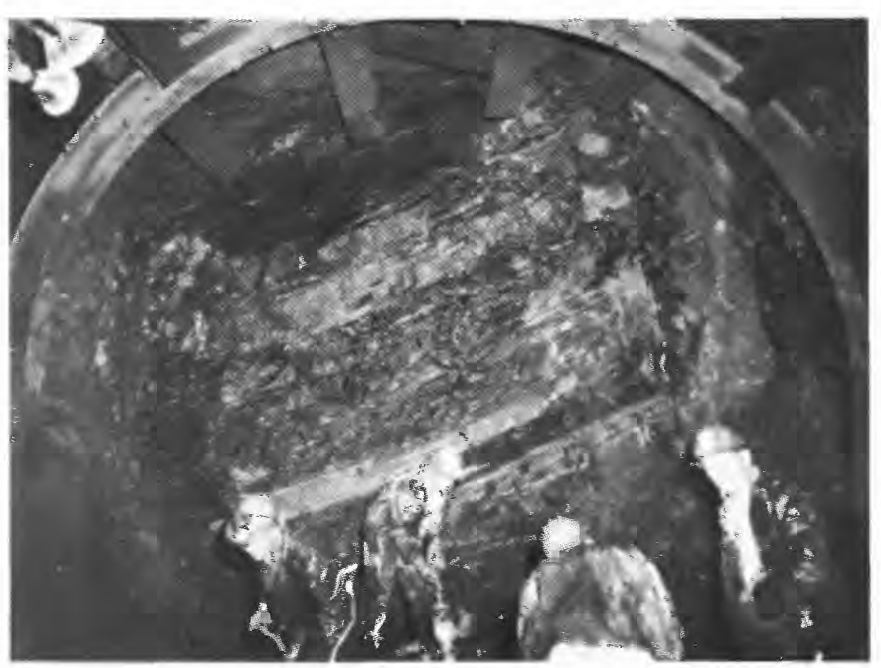

Figure 6.-Middle unit of the I)akota Group at station $38+44$, consisting of black shale and thin sandstone layers. Note crown bars extending beyond steel support to prevent collapse of arch.

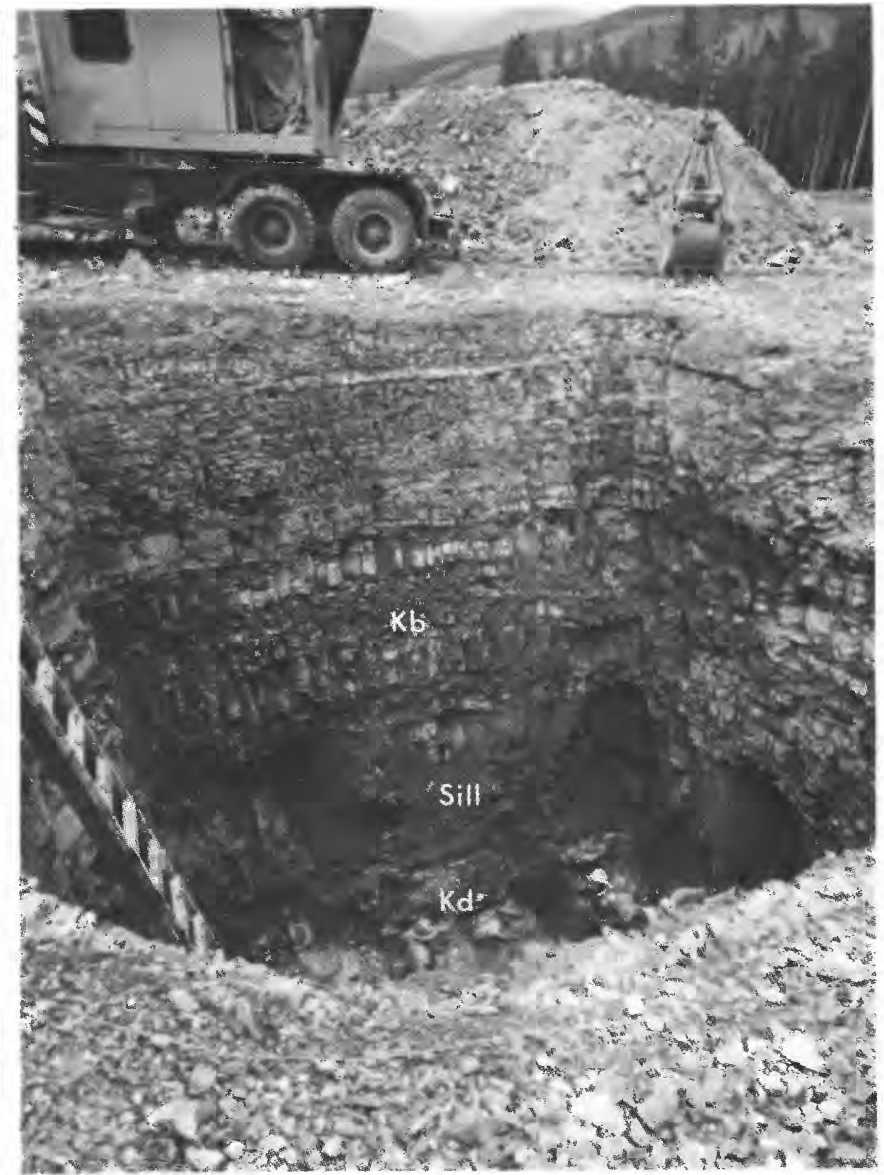

FIGURE 7.-Emergency gate shaft excavation at station 14+40 in well-bedded fissile shales of the Benton Shale, August 19, 1957. Note felsite porphyry sill at base of Benton Shale $(\mathrm{Kb})$ and above the Dakota Group (Kd).

exposures of the Dakota Group, but none were observed in the tunnel. A 40-foot-thick sill of felsite porphyry at the top of the Dakota Group and beneath the Benton Shale was intersected in the Access Shaft at station $14+40$ (fig. 7 ).

BENTON SHALE

The Benton Shale, of Early and Late Cretaceous age, is about 320 feet thick and consists of black carbonaceous shales and calcareous shales. Bedding is closely spaced and conspicuous, and the rocks as exposed in the tunnel are very fissile and split easily into thin layers. The shales are very fine grained and contain abundant silica, some feldspar, "illite" (2M muscovite), and minor amounts of kaolinite. Calcareous materials in the limy shales are calcite and lesser amounts of dolomite. The top 15-20 feet contains a succession of alternating thin beds of shale, limestone, and limy shale, below which is a shaly sandstone bed 10-20 feet thick. 
NIOBRARA FORMATION

The Niobrara Formation, of Late Cretaceous age, consists of two members: at the base, the Fort Hays Limestone Member, a dense thick-bedded limestone unit 15-20 feet thick; and at the top the Smoky Hill Marl Member, a closely bedded fissile succession of shaly limestones (fig. 8) and limy shales about 450 feet thick. The shaly limestones are black and rich in carbonaceous materials. Many beds have a petroliferous or fetid odor. The calcareous components are dominantly calcite, but some dolomite is present. Other components, exclusive of the organic carbonaceous materials, are clastic fine-grained quartz and small amounts of "illite" and kaolinite.

PIERRE SHALE

The youngest sedimentary unit beneath the Williams Range thrust fault, the Pierre Shale of Late Cretaceous age, is also the thickest sedimentary unit penetrated in the tunnel. From its base to the level where it is sheared off by the Williams Range thrust fault, it is about 2,500 feet thick. North of Dillon in the Blue River valley, sections from 5,000 to 5,500 feet thick have been measured, but even where the sections are the thickest, they terminate upward against the Precambrian rocks above the Williams Range thrust fault. A bed of shaly sandstone and siltstone, nearly 100 feet thick, is present about 750 feet above the base of the Pierre. Three sequences of

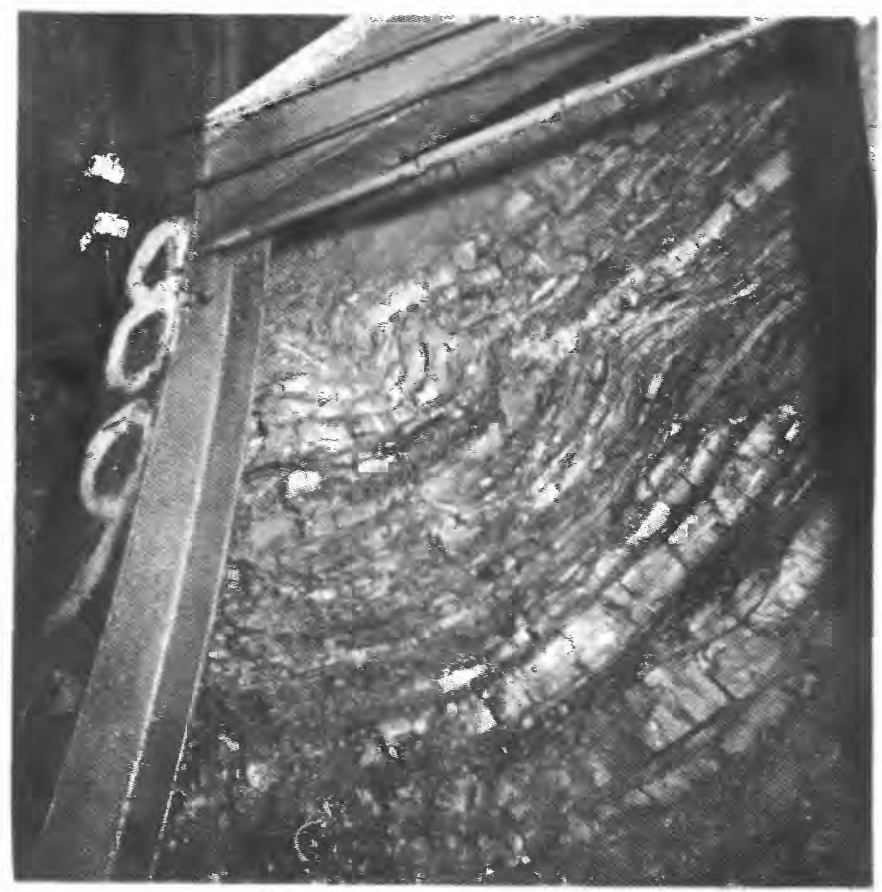

FIGURE 8.-Folded shaly limestone in the Smoky Hill Marl Member of the Niobrara Formation at station $56+50$. sandstone and siltstone are present in the thick Blue River valley exposures north of Dillon and probably were present in the section at Dillon before its upper part was sheared off by the thrust fault. Although the thrust fault prevents measurement of a complete section anywhere in the immediate area, the original total thickness of the Pierre Shale was probably on the order of 6,000 feet. The section below the thrust fault in the Roberts Tunnel probably represents from a third to a half of the total original thickness of the Pierre Shale in the area.

In weathered surface exposures, the Pierre Shale has normal shaly fissility; but in some sections of the tunnel, bedding is seen with difficulty, and the rock is nearly massive and breaks with a subconchoidal fracture. Elsewhere in the tunnel, bedding is conspicuous. Determinations of the bulk density of the shale gave results between 2.63 and 2.65 , values which are notably above the densities of 1.6 to 2.3 for Pierre Shale and similar shales from other localities. The abnormally high density of the shale probably is the result, in part, of mild desiccation by heat from a subterranean igneous body and, in part, of compaction from loading as the Williams Range thrust fault superimposed Precambrian rocks of the shale.

All beds in the Pierre Shale are black or dark gray and contain amorphous carbonaceous materials (fig. 9). The shales are very fine-grained, contain abundant "illite," kaolinite, nearly amorphous siliceous material, and some feldspar. The "illite" is a two-layer (2M) polymorph of muscovite. Minor amounts of chlorite and montmorillonite were detected in a few samples. The sandy shales contain angular to subangular fresh grains of quartz and feldspars, both potassium feldspar and plagioclase, in a matrix of the same substances that constitute the matrix of the fine-grained shales. The 100-footthick shaly sandstone and siltstone 750 feet above the base of the Pierre Shale consists of abundant angular to subangular grains of quartz, chert, feldspar, and rock fragments embedded in a matrix of "illite," kaolinite, and minor amounts of calcite and dolomite. The sandstone and siltstone are poorly bedded and have the fabric and mineral composition of a feldspathic graywacke.

\section{IGNEOUS ROCKS}

Sills of felsite porphyry are present in exposures of the Dakota Group above the tunnel and particularly in the quartzites in the crest of a small anticline exposed in the valley of the Snake River, east of Dillon. The only igneous rock exposed in the tunnel between the West Portal and station $180+00$ is a 


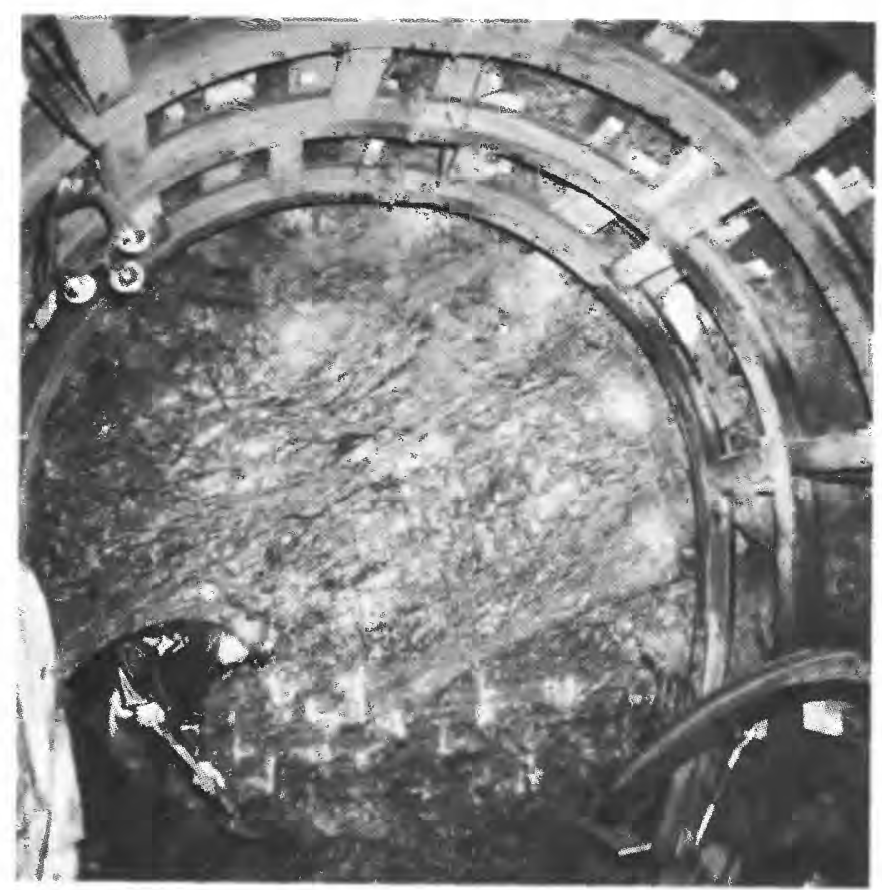

Figure 9.-Closely sheared black sandy shale of the Pierre Shale at station $178+88$.

devitrified felsite that forms the matrix of an intrusive breccia at station $125+50$. Numerous dikes and laterally extensive sills of dellenite (quartz latite) porphyry intruded shales of the Pierre over a broad area at least 2 miles south of the West Portal and probably are chemically equivalent to the felsite porphyry in the quartzites of the Dakota and the felsite in the intrusive breccia.

\section{STRUCTURAL GEOLOGY}

The dominant geologic structure in the vicinity of the West Portal of the Roberts Tunnel is the Williams Range thrust fault, which strikes generally north to northwest and dips approximately $30^{\circ}$ to the northeast. The fault resulted in superimposition of highly fractured Precambrian igneous and metamorphic rocks on Mesozoic sedimentary rocks. In most surface exposures, the fault truncates beds of the Pierre Shale. The effects of the development of the fault in the sedimentary rocks just below the thrust fault are apparent in highly sheared rocks of the Pierre Shale (fig. 9), but west of the exposure of the fault in the tunnel there are many faults and joint sets that do not bear an obvious geometric or time relationship to the thrust fault.

The sedimentary rocks beneath the thrust fault generally strike and dip in the same direction as the fault, but locally steep faults and minor folds cause sharp departures from the regional strike and dip of the sedimentary rocks. The dips of the sedimentary rocks near the West Portal are generally flatter than those near the fault where the bedding of the rocks is subparallel to the thrust-fault plane.

In the section of the tunnel between the West Portal (station 9+46) and the Williams Range thrust fault (station $180+00$ ), the attitudes of 245 bedding planes, 1,292 joints, and 688 faults were measured and plotted (pl. 1). Fractures were mapped as faults when there was evidence of movement, as indicated by gouge, striae, or visible dislocation of intersected rocks. The range of variations in the attitudes of the faults is indicated in the plot of poles of fault planes in figure 10. The only joints measured were conspicuous fracture surfaces that could be traced for several feet in tunnel exposures. No attempt was made to map small, discontinuous, or complexly intersecting joints, especially where these were in shattered zones associated with faults.

Planar elements were plotted on Schmidt equalarea nets projected from the lower hemisphere, and contours were drawn after counting out the poles with a 1-percent counter. The interval from the West Portal to station $180+00$ was divided into four sections in order that comparative structural analyses could be made (pl. 1). A section between the West Portal and station $47+00$ consists of flat-lying,

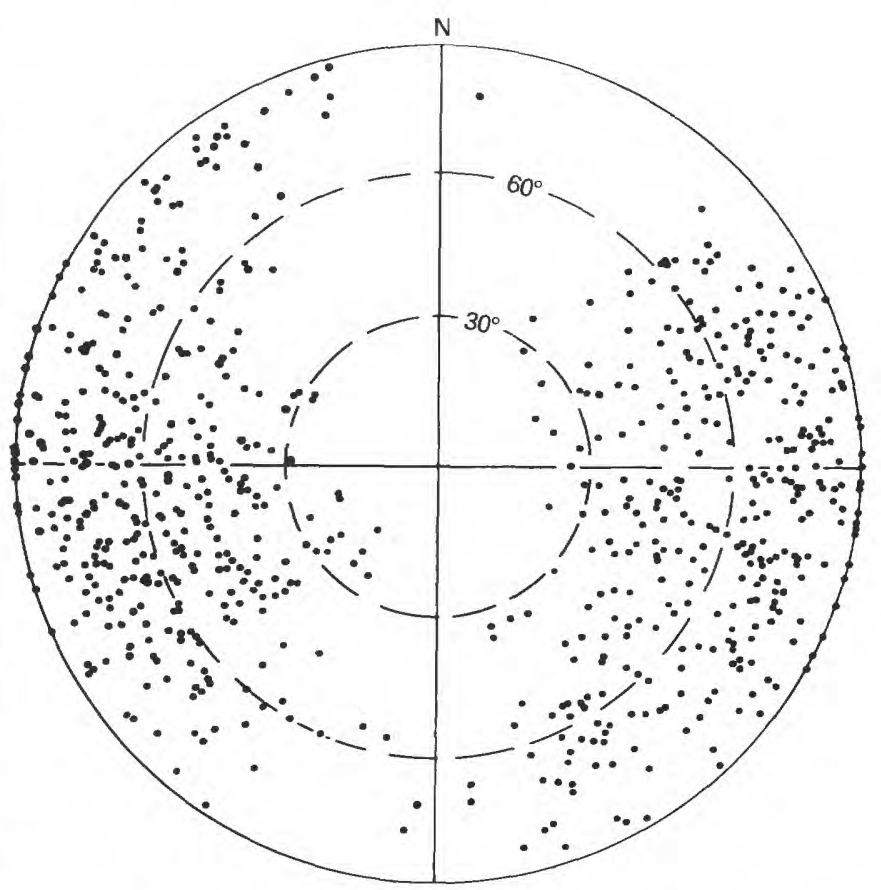

Figure 10.-Equal-area plot of faults between stations $9+46$ and $180+00$, Roberts Tunnel. 688 poles, lower hemisphere. $0^{\circ}-30^{\circ}, 3.2$, percent; $30^{\circ}-60^{\circ}, 31.7$ percent; $60^{\circ}-90^{\circ}, 65.1$ percent. 
gently folded brittle quartzites, sandstones, and shales of the Dakota Group, and where elevated by faulting to tunnel level, the mudstones of the Morrison Formation and the sandstones of the Entrada(?) Sandstone. The interval from station $47+00$ to station $180+00$ consists dominantly of shales that strike from N. $35^{\circ} \mathrm{W}$. to N. $50^{\circ} \mathrm{W}$. and dip from $18^{\circ}$ to $28^{\circ} \mathrm{NE}$; but broad, open folds between stations $70+00$ and $107+00$ and numerous small subsidiary folds between stations $95+00$ and $107+00$ produce local reversals of dip that are apparent in the equal-area plots. (pl. 1, bedding plane plots).

The following table compares average spacing of faults and strong joints in the four sections of the tunnel from the West Portal to station $180+00$. The number of faults and strong joints does not increase systematically in the direction of the Williams Range thrust fault. Most of the faults and joints dip steeply and strikes and dips (pl. 1) show no systematic, geometric arrangement with respect to the flatly dipping Williams Range thrust fault. The prominent fracture sets, however, tend to be subparallel or approximately normal to the bedding. They may be, in part, earlier fractures that were accentuated by bedding-plane slip induced by the Williams Range thrust fault, but some of them may be new fractures that were probably developed during and after thrusting. Generally, the more prominent fracture sets dip steeply and may be divided into two groups: one that strikes north to northwest, approximately parallel to the axis of the Front Range and to the trace of the Williams Range thrust fault; and another that strikes northeast, nearly parallel to the Front Range mineral belt.

Faults and joints

West Portal (station 9+46) to station 180+00 (Williams Range thrust fault)

\begin{tabular}{rrrrrrr}
\hline Stations & & $\begin{array}{c}\text { Number of } \\
\text { faults }\end{array}$ & $\begin{array}{c}\text { Average } \\
\text { spacing } \\
\text { (in feet) }\end{array}$ & $\begin{array}{c}\text { Number of } \\
\text { joints }\end{array}$ & $\begin{array}{c}\text { Average } \\
\text { spacing } \\
\text { (in feet) }\end{array}$ & $\begin{array}{c}\text { Faults plus } \\
\text { joints, } \\
\text { average } \\
\text { (in feet) }\end{array}$ \\
\hline $9+46$ to $47+00$ & 70 & 53.6 & 451 & 8.3 & 7.2 \\
$47+00$ to $92+00$ & 143 & 31.5 & 292 & 15.4 & 10.3 \\
$92+00$ to $137+00$ & 303 & 14.8 & 180 & 25.0 & 9.3 \\
$137+00$ to $180+00$ & 172 & 26.2 & 369 & 12.2 & 8.3 \\
\hline
\end{tabular}

The block diagrams of figure 11 show typical relationships between bedding, faults, and joints in the four sections of the tunnel for which the statistical plots were made on plate 1 . The attitudes of the planar elements correspond to the concentrations (maxima) in the equal-area plots on plate 1 , and the diagrams are not intended to represent actual specific conditions in any section of the tunnel but, rather, indicate "average" conditions within each of the four tunnel intervals that correspond to the diagrams.

\section{ENGINEERING PRACTICES IN RELATION TO GEOLOCY}

During construction of a tunnel, the engineering practices are directly related to the geologic conditions. Such factors as the amount of overbreak and the shape of the tunnel, the need for feeler holes for detecting ground water or poor ground in advance of the heading, support requirements, and progress are related to the apparent attitude and the fissility of the bedding, frequency and orientation of the joints, and the presence of gouge in or along faults in sheared rock. A summary of the engineering practices is shown graphically with the geologic plan and section for this interval of the tunnel on plate 1.

\section{PAYLINE AND OVERBREAK}

A contractor is paid for excavating a certain amount of rock when constructing a tunnel; the line drawn in a cross section of the tunnel that defines this limit of excavation is called the payline (fig. 12). Any material excavated outside the payline is defined as overbreak, and a contractor is not paid for excavating that material. For this reason, a contractor will make every effort to hold the overbreak to a minimum; moreover, the contractor is not paid for concrete placed outside the payline during the tunnel lining operation.

Within the Roberts Tunnel, in unsupported sections, the payline is 4 inches outside the " $B$ " line in the walls and arch (fig. 12A) and coincides with the " $B$ " line in the invert excavation. In supported sections the payline is 6 inches outside the " $B$ " line in the walls and arch and coincides with the " $B$ " line in invert excavation over most of its breadth (fig. 12B). In supported sections the space between the "B" line and payline was designed to allow room for the placement of crown bars, timber lagging, and wedges between the steel supports and the rock.

The overbreak was calculated by comparing the area actually excavated with the area inside the payline, as measured in cross sections of the tunnel at 10-foot intervals throughout the length of the tunnel. The tunnel sections were measured by determining distances from the centerline to rock at $10^{\circ}$ intervals around the tunnel. Distances from the centerline to the walls and arch were more significant than distances to the invert, because the contractor completed excavation of the invert and cleaning up of rock debris just prior to placing 

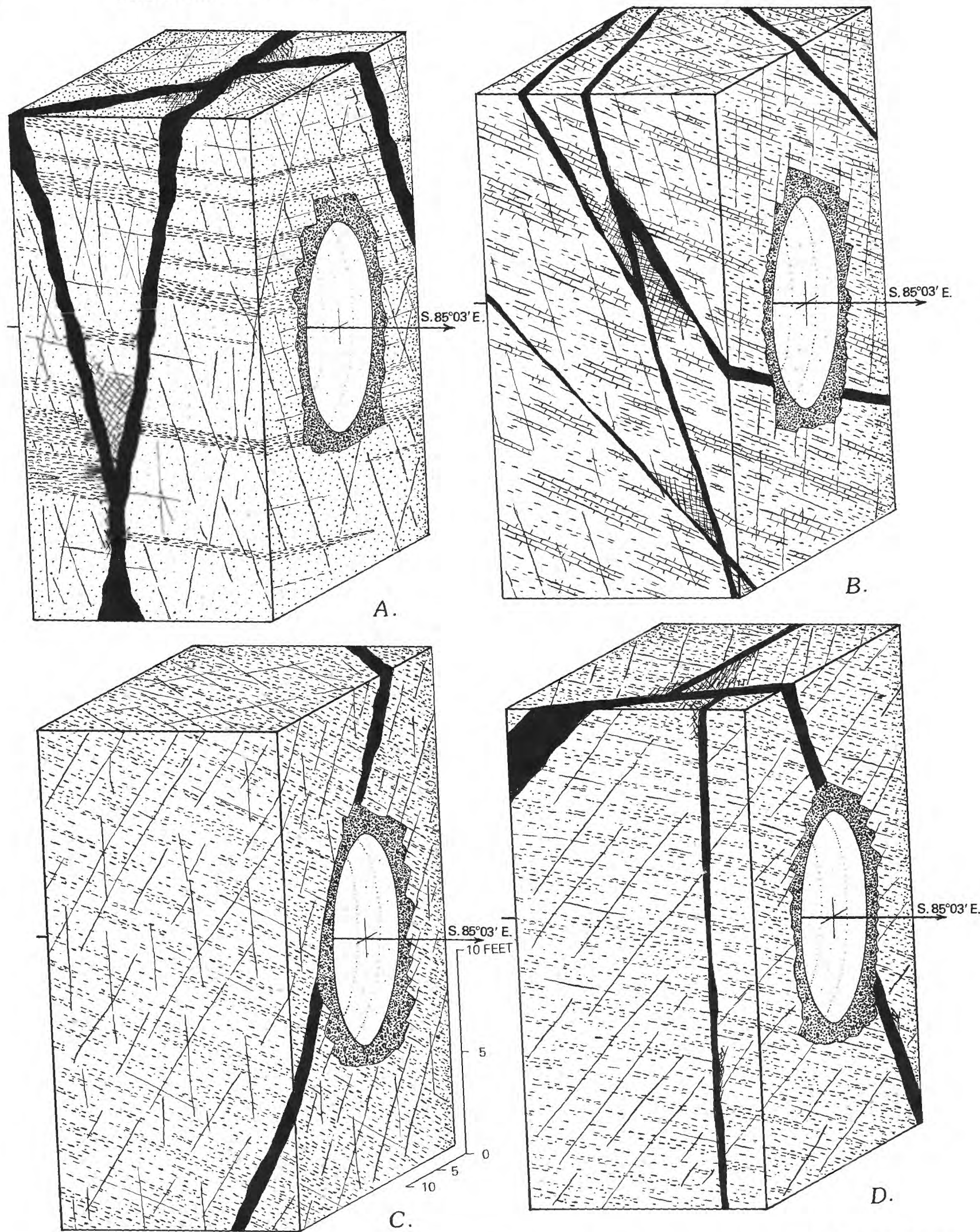

C. Figure 11.-Diagram showing typical average attitudes of bedding, faults, and joints in the Roberts Tunnel between
The stations $9+46$ (West Portal) and lined tunnel is 10.25 feet. Arrows indicate direction of tunnel heading (S. $D$, stations plate 1. Diameter of finished lined A, Stations $9+46$. 


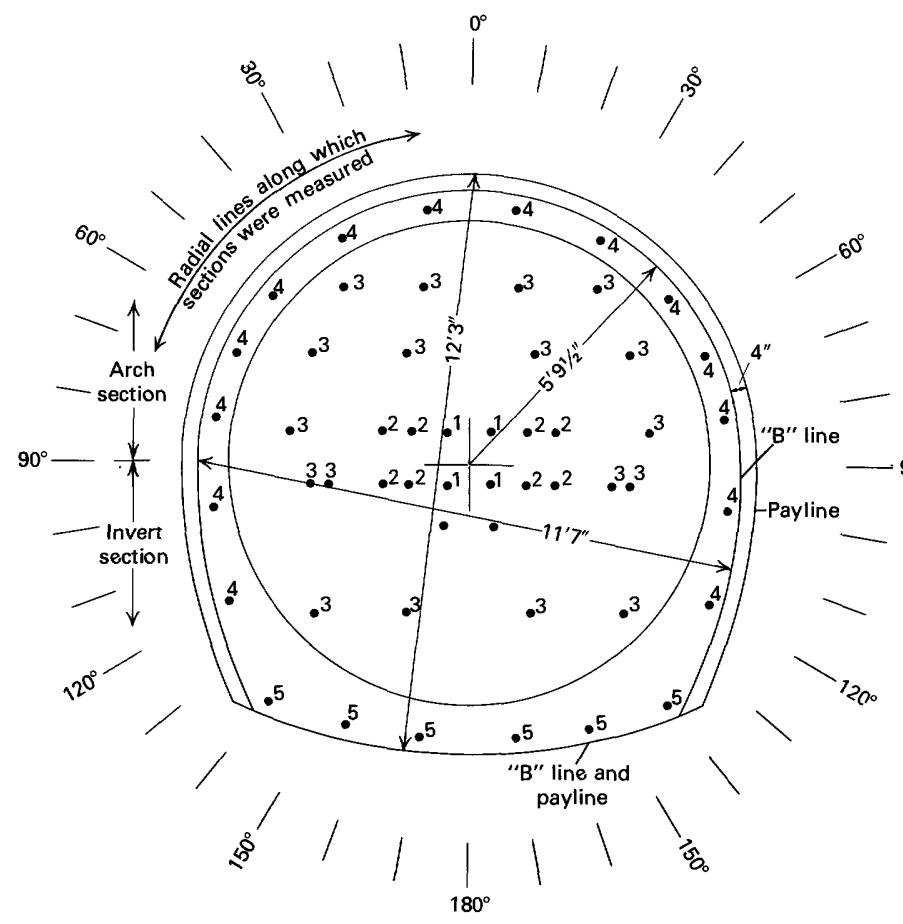

A. Pattern for unsupported section

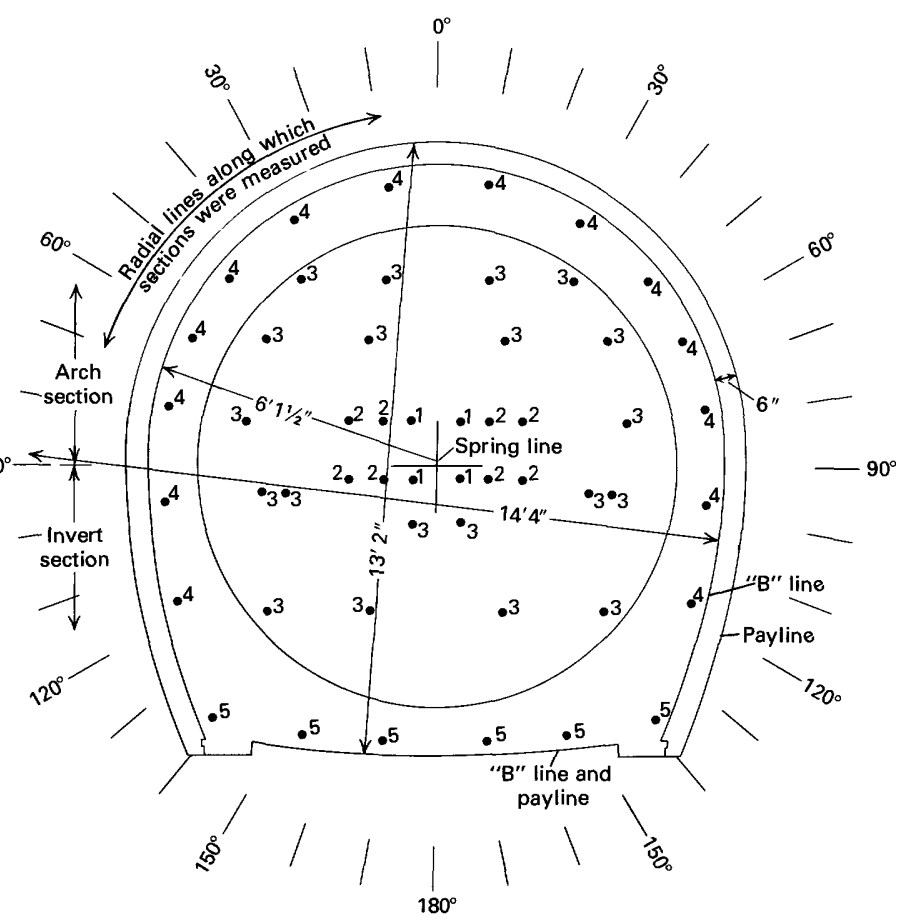

B. Pattern for supported section

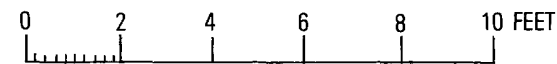

FIgURE 12.- Blasthole patterns and tunnel configuration, Roberts Tunnel. Blast sequence: $1-4$ "Baby" cuts (1 delay primer); $2-8$ cuts (2, 3 delay primers); $3-20$ relievers $(4,5,6$ delay primers); $4-14$ shape holes ( $7,8,9$ delay primers); $5-6$ lifters (9 delay primers). "B" line is the line within which no excavated material, tamped fill, lagging, spiling, crownbars, spreaders, collar braces, or wallplates shall remain. Payline is the line to which a contractor is paid for excavating material.

concrete lining. In the following descriptions, the only overbreak that was calculated was that above the invert excavations.

Many factors contributed to the amount and nature of the overbreak. Among these were the degree and attitude of the bedding, the extent and orientation of fracturing, the brittleness or tenacity (toughness) of the rock, the location and depth of the blastholes, and the size of the explosive charges placed in the blastholes. Overbreak also resulted from mucking operations at the sides of the invert, especially in soft or fractured rocks, and from shattering of rocks where muck blasted from the tunnel heading accumulated in the lower part of the tunnel heading and tended to confine the effect of the explosions in the lower shape holes and lifters (fig. 12).

Figure 12 shows typical blasthole patterns used by the contractor. Locations of the holes were made at the heading by means of a line painted on the face indicating the location of the " $B$ " line; or where steel supports were placed just behind the face, the location of the " $B$ " line was estimated from the outline of the steel sets. The depths and angles of the drill holes were based on the contractors's experience in each type of rock and were adjusted to yield minimum overbreak and maximum progress of the tunnel heading. The shape holes above the spring line were located radially with respect to the spring line in supported sections and radially with respect to the centerline in unsupported sections. Below the spring line (or centerline) the shape holes were positioned with radii longer than those above the spring line. Generally, the drilling and blasting operation was one of the most constant factors of the tunneling operation, and overbreak was more the result of variations in the composition and structure of the rocks than of poor drilling and blasting procedures.

Plates 2 and 3 show tunnel cross sections and the geology in plan and section for various intervals of the Roberts Tunnel in the sedimentary rocks penetrated between the West Portal and station $180+00$; these sedimentary rocks consist of marine shales, limy shales, shaly limestones, sandy shales, and shaly sandstones above the Dakota Group and below the Williams Range thrust fault. Except where the sedimentary rocks are folded, are dragged along 
faults, or are tilted in fault blocks, the bedding strikes northwest and dips from a few degrees to as much as $30^{\circ}$ to the northeast (pl. 1). The various parts of the tunnel are described in order of increasing stationing without respect to the stratigraphic sequence of the sedimentary rocks. Most of the illustrated intervals were taken from parts of the tunnel where faults and joints were at a minimum, so as to determine the effect of bedding-plane fissility in overbreak. Sections between stations $68+16$ and $69+56,98+16$ and $99+56$, and $173+26$ and $174+66$, however, were selected to show the nature of overbreak in intensely fractured rocks where maximum support was required. Most sections show some ellipticity in the arch above the spring line.

Table 1 summarizes the data presented on plates 2 and 3.

Plate $2 A$ shows the arithmetic mean of 15 sections between stations $12+26$ and $13+66$. Also shown are overbreak maxima for all the sections and a single section with maximum overbreak. The rocks in this interval are hard, brittle, poorly bedded, nearly massive quartzites of the Dakota Group. Joints are locally conspicuous and generally intersect the bedding at large angles. Irregularities in the cross sections were largely determined by joints, and where joints were absent, the outlines of sections closely paralleled the payline. An average overbreak of 20.17 percent resulted from the necessity of using heavy blasting charges to break the hard, brittle quartzose rocks.

Plate $2 B$ indicates the outlines of tunnel cross sections between stations $27+46$ and $28+86$ in the Entrada(?) Sandstone. The sandstone is crossbedded and generally is friable. Some samples are so poorly cemented that they crush easily and break down into sandy aggregates of quartz grains of uniform size. Others are well cemented, hard, and brittle. Generally, the Entrada(?) Sandstone yielded smooth tunnel sections with minimum overbreak and, in spite of the bedding, behaved virtually as an isotropic medium. The average arch section is nearly circular. Local irregular overbreak resulted from steeply dipping fractures as in the Dakota quartzite.

Overbreak in a section of the Morrison mudstone between stations $34+46$ and $35+96$ is indicated on plate $2 C$. Bedding is inconspicuous in a very fine grained, highly siliceous mudstone; and steeply dipping joints are numerous. The mudstone in this part of the tunnel consists of intercalated beds of calcitic mudstone, which resembles lithographic limestone, and softer, less brittle beds which contain little or no calcite. The noncalcareous beds contain small amounts of crystalline clay minerals, especially montmorillonite, and they tended to slack and slough when wet, which created a slight tendency for the rock to break to a slightly elliptical cross section in the arch section.

Sections in shales and quartzites of the Dakota Group between stations $43+66$ and $45+16$ are shown on plate $2 D$ and enable comparison of overbreak in fissile rocks with overbreak in the massive quartzites of the Dakota Group encountered in the tunnel between stations $12+26$ and $13+66(\mathrm{pl} .2 A)$. The tunnel cross sections on plate $2 D$ are less symmetrical than on plate $2 A$ and show an ellipticity, which resulted from splitting of the rocks to shaly partings during the blasting operation.

\section{SHAPES OF TUNNEL CROSS SECTIONS}

Departure of the shapes of excavated cross sections from the shape of the payline cross sections in the Roberts Tunnel in the sedimentary rocks between the West.Portal and the Williams Range, thrust fault depended on several factors, but mainly on the attitude of the bedding and on the fissility or ease of splitting along bedding planes. Locally, in highly fractured rocks, the shape was determined by the extent, orientation, and spacing of joints or on the presence or absence of thoroughly sheared, gougy materials in or along faults. Except where fracturing rendered the rocks incompetent, the sedimentary rocks were strong enough to require just enough support to prevent rockfalls that tended to develop by separation along bedding planes in rocks disturbed by the blasting operation.

Plate $3 E$ presents a graphical analysis of variations in shapes of cross sections in the arch section above the spring line (stas. $173+26$ to $174+66$ ). This portion of the tunnel was chosen for the analysis because blastholes were located at equal distances on radial lines from the spring line and under ideal conditions the excavated cross section would tend to be circular. Below the spring line, shape holes were located with reference to a different set of radii, and they resulted in a total cross section of horseshoe shape. Moreover, blasting and mucking operations produced irregularities that would not be developed in the arch section. On plate $3 E$, ten average sections above the spring line in relatively unfractured rocks were plotted after rotating the sections so that all would conform to an apparent dip of $20^{\circ}$ of bedding as observed at the tunnel heading. Lines were drawn to enclose the area occupied by the average arch sections, an area indicated on plate $3 E$ by pattern. Three average sections for intensely fractured rocks were similarly rotated and plotted, 
TABLE 1.-Overbreak in tunnel cross sections, stations $0+00$ to $180+00$

\begin{tabular}{|c|c|c|c|c|c|c|c|}
\hline Stations & $\begin{array}{l}\text { Plate } \\
\text { No. }\end{array}$ & $\begin{array}{l}\text { Sedimentary } \\
\text { formation }\end{array}$ & $\begin{array}{l}\text { Primary characteristics } \\
\text { in tunnel interval }\end{array}$ & Fracturing & $\begin{array}{c}\text { Average } \\
\text { overbreak } \\
\text { (arithmetic } \\
\text { mean, in } \\
\text { percent) }\end{array}$ & $\begin{array}{c}\text { Maximum } \\
\text { overbreak } \\
\text { in a single } \\
\text { section } \\
\text { (percent) }\end{array}$ & Remarks \\
\hline $12+26$ to $13+66$ & $2 A$ & Dakota Group & $\begin{array}{l}\text { Hard, brittle nearly } \\
\text { massive quartzite } \\
\text { with a few shale } \\
\text { partings. }\end{array}$ & $\begin{array}{l}\text { Joints nearly perpen- } \\
\text { dicular to bedding. }\end{array}$ & 20.7 & 41.0 & $\begin{array}{l}\text { Required maximum explo- } \\
\text { sive charges. Arch } \\
\text { section nearly circular. }\end{array}$ \\
\hline $27+46$ to $28+86$ & $2 B$ & $\begin{array}{l}\text { Entrada(?) } \\
\text { Sandstone }\end{array}$ & $\begin{array}{l}\text { Hard to soft, cross- } \\
\text { bedded, commonly } \\
\text { friable sandstone. }\end{array}$ & $\ldots$. do $\ldots$ & 9.1 & 14.9 & $\begin{array}{l}\text { Easily excavated. Arch } \\
\text { section nearly circular. }\end{array}$ \\
\hline $34+46$ to $35+96$ & $2 C$ & $\begin{array}{l}\text { Morrison } \\
\text { Formation }\end{array}$ & $\begin{array}{l}\text { Hard to soft, poorly } \\
\text { to well bedded, very } \\
\text { fine grained, locally } \\
\text { calcareous mudstone. }\end{array}$ & $\begin{array}{l}\text { Numerous joints nearly } \\
\text { perpendicular to } \\
\text { bedding. }\end{array}$ & 7.8 & 18.6 & $\begin{array}{l}\text { Easily excavated. Arch } \\
\text { section nearly circular. }\end{array}$ \\
\hline $43+66$ to $45+16$ & $2 D$ & Dakota Group & $\begin{array}{l}\text { Hard, brittle sandstone } \\
\text { and well-bedded, } \\
\text { siliceous, fissile } \\
\text { shale. }\end{array}$ & $\begin{array}{l}\text { Steeply dipping } \\
\text { joints. }\end{array}$ & 13.9 & 35.56 & $\begin{array}{l}\text { Breaks to joints and } \\
\text { bedding planes in shale. } \\
\text { Irregular arch sections. }\end{array}$ \\
\hline $48+86$ to $50+26$ & $2 E$ & Benton Shale & $\begin{array}{l}\text { Closely bedded, } \\
\text { fissile shale. }\end{array}$ & $\begin{array}{l}\text { Strong joints } \\
\text { not numerous. }\end{array}$ & 15.6 & 27.5 & $\begin{array}{l}\text { Breaks easily to bedding } \\
\text { planes. Arch somewhat } \\
\text { elliptical. }\end{array}$ \\
\hline $52+86$ to $54+26$ & $2 F$ & Benton Shale & $\begin{array}{l}\text { Closely bedded, } \\
\text { fissile calcareous } \\
\text { shale. Brittle. }\end{array}$ & Few joints. & 10.9 & 16.1 & $\begin{array}{l}\text { Breaks easily to bedding } \\
\text { planes. Arch somewhat } \\
\text { elliptical. }\end{array}$ \\
\hline $57+56$ to $59+06$ & $2 G$ & $\begin{array}{l}\text { Niobrara Formation, } \\
\text { Smoky Hill } \\
\text { Marl Member }\end{array}$ & $\begin{array}{l}\text { Well-bedded, fissile } \\
\text { shaly limestone. }\end{array}$ & $\begin{array}{l}\text { Joints not } \\
\text { conspicuous. }\end{array}$ & 10.2 & 17.8 & $\begin{array}{l}\text { Breaks easily to bedding } \\
\text { planes. Elliptical arch. }\end{array}$ \\
\hline $68+16$ to $69+56$ & $2 H$ & -- do $-\cdot$ & $\begin{array}{l}\text { Closely bedded, } \\
\text { fissile calcareous } \\
\text { shale. }\end{array}$ & $\begin{array}{l}\text { Intense fracturing, } \\
\text { generally across } \\
\text { bedding. }\end{array}$ & 33.3 & 45.0 & $\begin{array}{l}\text { Shattered. Required exten- } \\
\text { sive support. Elliptical } \\
\text { sections parallel to } \\
\text { bedding. Breaks easily to } \\
\text { cross fractures. }\end{array}$ \\
\hline $84+46$ to $85+86$ & $3 A$ & Pierre Shale & $\begin{array}{l}\text { Inconspicuously } \\
\text { bedded shale. }\end{array}$ & $\begin{array}{l}\text { Fractures not } \\
\text { conspicuous. }\end{array}$ & 12.4 & 20.5 & $\begin{array}{l}\text { Easily excavated. Arch } \\
\text { somewhat elliptical. } \\
\text { Breaks to bedding planes. }\end{array}$ \\
\hline $98+16$ to $99+56$ & $3 B$ & --do--- & Sandy shale. & $\begin{array}{l}\text { Intensely crushed. } \\
\text { Fractures commonly } \\
\text { parallel to bedding } \\
\text { and emphasize bedding. }\end{array}$ & 14.3 & 37.3 & $\begin{array}{l}\text { Maximum support required. } \\
\text { Arch section strongly } \\
\text { elliptical or breaks } \\
\text { into Gothic arch. }\end{array}$ \\
\hline $108+06$ to $109+46$ & $3 C$ & --do--- & $\begin{array}{l}\text { Sandy shale. Bed- } \\
\text { ding conspicuous, } \\
\text { fissile. }\end{array}$ & $\begin{array}{l}\text { Joints not } \\
\text { conspicuous. }\end{array}$ & 10.9 & 22.7 & $\begin{array}{l}\text { Breaks easily to bedding } \\
\text { planes. Arch elliptical. }\end{array}$ \\
\hline $110+16$ to $111+56$ & $3 D$ & $\cdots$ do $\cdots$ & $\begin{array}{l}\text { Shaly sandstone. } \\
\text { Bedding incon- } \\
\text { spicuous. }\end{array}$ & $\begin{array}{l}\text { Joints not } \\
\text { abundant. }\end{array}$ & 8.6 & 10.7 & $\begin{array}{l}\text { Breaks uniformly. Arch } \\
\text { section nearly circular. }\end{array}$ \\
\hline $173+26$ to $174+66$ & $3 E$ & --do-- & $\begin{array}{l}\text { Sandy shale. Bed- } \\
\text { ding inconspicuous. }\end{array}$ & $\begin{array}{l}\text { Intensely faulted and } \\
\text { jointed. Joints } \\
\text { generally intersect } \\
\text { bedding at large } \\
\text { angles. }\end{array}$ & 28.0 & 44.3 & $\begin{array}{l}\text { Breaks mainly to joints. } \\
\text { Arch slightly elliptical; } \\
\text { major axis parallel } \\
\text { to bedding. }\end{array}$ \\
\hline
\end{tabular}

and a section showing an arch profile at station $98+16$ was added.

In unfractured sedimentary rocks the shape of the area above the spring line ranged from circular to elliptical. In nearly massive rocks, such as thick quartzite beds in the Dakota Group, crossbedded friable sandstones of the Entrada(?) Sandstone, and poorly bedded, very fine grained mudstones of the Morrison Formation, the section is virtually circular, but the radii of the circles increase with the brittleness of the rock. In fissile, bedded rocks the shape is elliptical, and the length of the long axis of an inscribed ellipse relative to the shorter axis increases as the fissility increases. In all elliptical sections in undisturbed sedimentary rocks, the longer axis of the ellipse is perpendicular to the apparent dip of the bedding. The extreme ellipticity-defined by the ratio of the major and minor axes for the sedimentary rocks with maximum fissility-is 1.1 , a ratio nearly corresponding to 
ratios in closely bedded shales and limy shales in the Benton Shale. In highly jointed fissile shaly limestone and limy shale of the Niobrara Formation between stations $68+16$ and $69+56$, a longer elliptical axis parallel to the bedding is attributed to the fact that closely spaced joints intersect the bedding and that the rock splits more easily across the bedding than parallel to it.

Some sections of the tunnel passed through completely pulverized rocks, and because of the tendency of the rock to squeeze into the tunnel, no cross sections could be measured. This condition existed in several gougy faults and in the highly fractured rocks between stations $179+86$ and $180+26$, within and just below the Williams Range thrust fault. An intermediate condition was observed in several sections where, although the rocks were pervasively shattered, they developed arches that held the rocks long enough to enable measurement of cross sections. On plate $3 B$ the arching tendency is seen in the sections for the interval of broken rocks between stations $98+16$ and $99+56$. This interval contains complexly folded and fractured sandy shales of the Pierre Shale. Joints are so numerous and have such diverse attitudes that bedding is practically obliterated, but the individual fragments of shale are hard and fresh. The arch formed during blasting assumed a Gothic arch cross section above the spring line. For the section between stations $98+16$ and $99+56$, the arch ratio (defined as the ratio of the length of the radius from the spring line to the highest point on the arch to one-half the width of the tunnel cross section at spring-line elevation) is 1.16 for the average and 1.36 for the single section showing maximum arching in this interval. In other parts of the tunnel, isolated cross sections showed arch ratios of as much as 1.40 to 1.45 .

\section{FEELER HOLES, GROUND WATER, AND GROLTING}

Feeler holes 25-200 feet deep were drilled into the tunnel heading with percussion drills or diamond drills when there was some indication of faulted, highly jointed, or water-bearing rocks beyond the heading. Commonly, the holes were drilled to test ground-water conditions; and, if water was encountered in appreciable amounts, grout was pumped into the holes in an effort to seal off or diminish the waterflow. Grout mixtures were varied from thin mixtures of 8-10 volumes of water to 1 volume of cement (a sack of cement was assumed to have a volume of 1 cubic foot) to mixtures of 1 part water and 1 part cement. The grouting was continued under pressures of as much as $1,000 \mathrm{psi}$ (pounds per square inch) to the point of refusal or until the waterflow apparently had been stopped. A typical result of feeler hole exploration in the tunnel heading is shown in figure $13 \mathrm{~A}$.

The pressure to be used in pumping grout into the feeler holes was a matter of debate and was determined at the heading by arbitrary decisions based on the nature of the rocks and the fracture pattern in them and on the pressure of the ground water, as measured at the nipples of the feeler holes. A consequence of the use of excessive pressure is indicated in figure $13 B$, which shows quartzite layers of Dakota buckled by grout traveling along bedding planes and the failure of steel supports caused by the buckling.

Very heavy waterflows were encountered at and behind the heading at station $38+65$ where steeply dipping faults in quartzite of Dakota Group carried sufficiently large volumes to flood the tunnel. Attempts to seal off the flow by grout holes from the tunnel were unsuccessful, and it was necessary to construct a bulkhead before sufficient grout could be pumped in to the fault zone to permit normal advance of the heading. Figure $13 C$ shows a stage in the construction of the bulkhead.

A summary prepared by H.J. Dickinson, Construction Engineer, and taken from the progress report for the period May 15-May 31, 1957, indicates the details of bulkhead construction and grouting with the heading at station $38+65$ :

The first bulkhead was made of alternate layers of sacked sand and cement and extended back from the heading for a distance of 12 feet. The height of the bulkhead was 6 feet and it was blocked down from the back of the tunnel with wooden timber. The front of the bulkhead was formed with $6 \times 8$ in. timber and caulked with oakum. Two well points were placed in the tunnel invert beneath the bulkhead for relieving the water pressure, and four grout pipes were placed intermittently in the bulkhead for filling the voids between the sacks with grout. Ten feeler holes were drilled into water bearing seams and connecting pipes for grouting were extended out through the bulkhead. The first bulkhead was not completed until the swing shift on 14 May, the progress of the work being retarded because of inadequate pumping facilities. Upon completion of the bulkhead, grouting operations were commenced immediately. A total of 1,630 sacks of cement were used in grouting the bulkhead and the ten feeler holes. A grout mix of 1:1 was used with a maximum pumping pressure of 250 psi. The seepage was reduced from 1,300 GPM to 600 GPM, [gallons per minute]. However, during this grouting another large water bearing seam broke out in the tunnel invert about 8 feet back from the face of the bulkhead. The grouting also failed to shut off the water coming from under the bulkhead. It was then decided that this bulkhead should be removed and replaced with a solid type and longer bulkhead.

On 16 May the first bulkhead was removed and the tunnel invert 
was thoroughly cleaned. On the following day the workmen began drilling new feeler holes. The drilling operations were continued through 20 May and during that time grout pipes were installed in the feeler holes.

On 21 May the Contractor began the construction of the second bulkhead. The design of the new bulkhead was approved during the meeting held with the Contractor on 17 May. It was agreed that the new bulkhead would extend 38 feet back from the face of the tunnel and would consist of a 20 -foot grouted gravel section and an 18-foot solid concrete section. The construction of the new bulkhead was completed during the swing shift on 25 May. After the concrete had been allowed to set 24 hours, the joint around the perimeter of the tunnel in the concrete section was low pressure grouted and eight hours after this grouting was completed the Contractor began grouting the 20 -foot gravel section. All the low pressure grouting which included the contract grouting in the concrete section and the gravel section was completed on 28 May. A total of 1856 sacks of cement were used in this grouting operation. After the low pressure grouting was completed, the Contractor immediately proceeded with the feeler hole or high pressure grouting. A total of 27 feeler holes were grouted and a total of 4354 sacks of cement were used in this operation. The maximum grouting pressure was approximately 750 psi and the average grout mixture was 1:1. All grouting was completed at noon on 29 May. Since the completion of the grouting, ten feeler holes have been drilled and no water has been encountered. The removal of the bulkhead is scheduled to commence at the beginning of graveyard shift on 3 June.

Plate 1 includes a graphical summary of the feelerhole and grouting operations and indicates the estimated amount of water in gallons per minute per foot of tunnel for wet sections; plate 1 also shows the locations of heavy waterflows into the tunnel.

Plates 6 and 7 show feeler holes, ground water, and grouting for selected parts of the tunnel on a larger scale than on plate 1 .

All the high-volume flows in the Roberts Tunnel between the West Portal and station $180+00$ were located in or near faults and associated fractures that intersect brittle and very hard quartzite beds of Dakota Group or Entrada(?) Sandstone. The mudstones of the Morrison Formation tended to swell slightly, tended to behave plastically, and did not have open, interconnecting fissures. Shales and limy shales in the sedimentary layers above the Dakota Group also yielded only slight amounts of water. Grouting was required where small amounts of water was encountered in shaly limestone in the Niobrara Formation and in sandy beds in the Pierre Shale. As in the quartzites of the Dakota Group, the amount of permeability is the result of faults and associated joints.

On June 15, 1958, when the tunnel heading was at station $179+98$, water pumped from the tunnel and measured at the West Portal averaged about 900 gallons per minute; this amount of water indicated the extent to which it was not feasible to seal off all water flows encountered in the sedimentary rocks between the West Portal and the Williams Range thrust fault.

Feeler holes drilled through highly sheared, dry shales to intercept and test the fault at station $180+00$ (pls. 7,8 ) passed through a gouge zone and then intercepted waterflows in crushed Precambrian gneiss above the fault. Water from the feeler holes spread through the shales west of station $180+00$ and caused shale to start moving into the tunnel. Attempts to seal off the water with grout were futile, and it was necessary to place extra supports in the shale section behind the heading to prevent the wet shale from collapsing and running into the tunnel.

\section{SUPPORTS}

Six-inch steel supports were placed in 2.5-, 3.0-, 4.0-, and 5.0-foot centers as required in the section between the West Portal and station $180+00$ (pl. 1). Supports were required for 75.5 percent of the interval between the West Portal and station $43+14$ where a few sections of quartzite of the Dakota Group were sufficiently competent to stand without support. Supports were placed in the entire interval between stations $43+14$ and $180+00$ where the tunnel intersected shales, limy shales, limestones, sandy shales, and shaly sandstones of the Benton Shale, the Niobrara Formation, and the Pierre Shale.

Factors contributing to the necessity for support were bedding-plane fissility, faults, and joints, especially those which contained water under pressure. Supports on 4.0- and 5.0-foot centers with timber lagging provided an adequate safety factor where bedding-plane fissility produced a tendency for rockfalls in flatlying sedimentary rocks or where joints were not closely spaced. Steel supports on 2.5 and 3.0-foot centers were used where the tunnel passed through wide zones of highly fractured gougy rock that were associated with faults. A close correlation between faulting and closely spaced supports is seen on plate 1 , which graphically shows support spacing as related to gross features of geology in plan and section.

Plates 6 and 7 indicate the detailed relationships between support and geology for five selected sections of the tunnel and show a close correlation between heavily supported intervals and the extent and intensity of the fracturing in the rocks.

The steel and timber supports in Roberts Tunnel were regarded as temporary supports placed to contain incompetent rocks until concrete lining could be placed. The tunnel lining of concrete was 

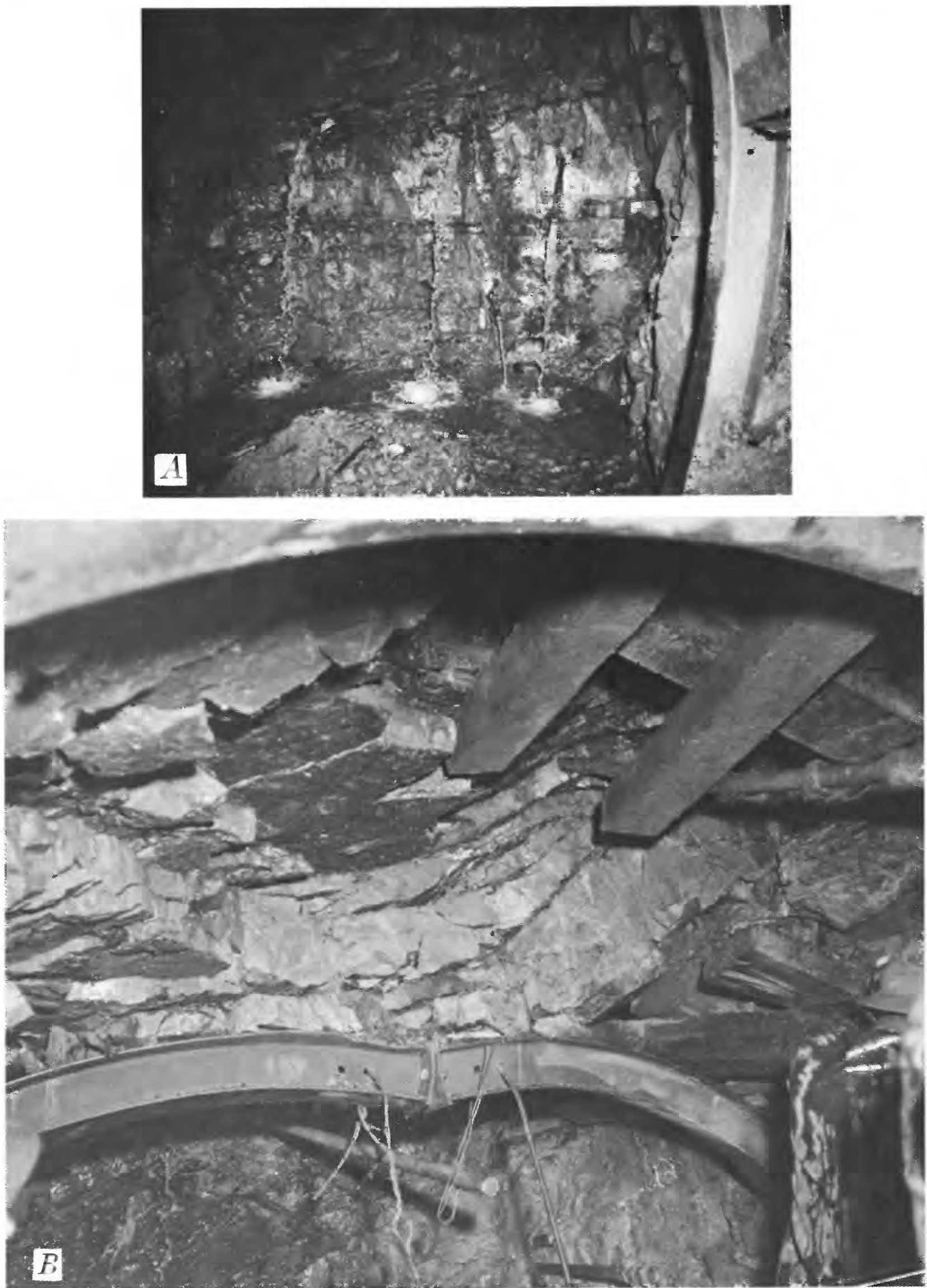


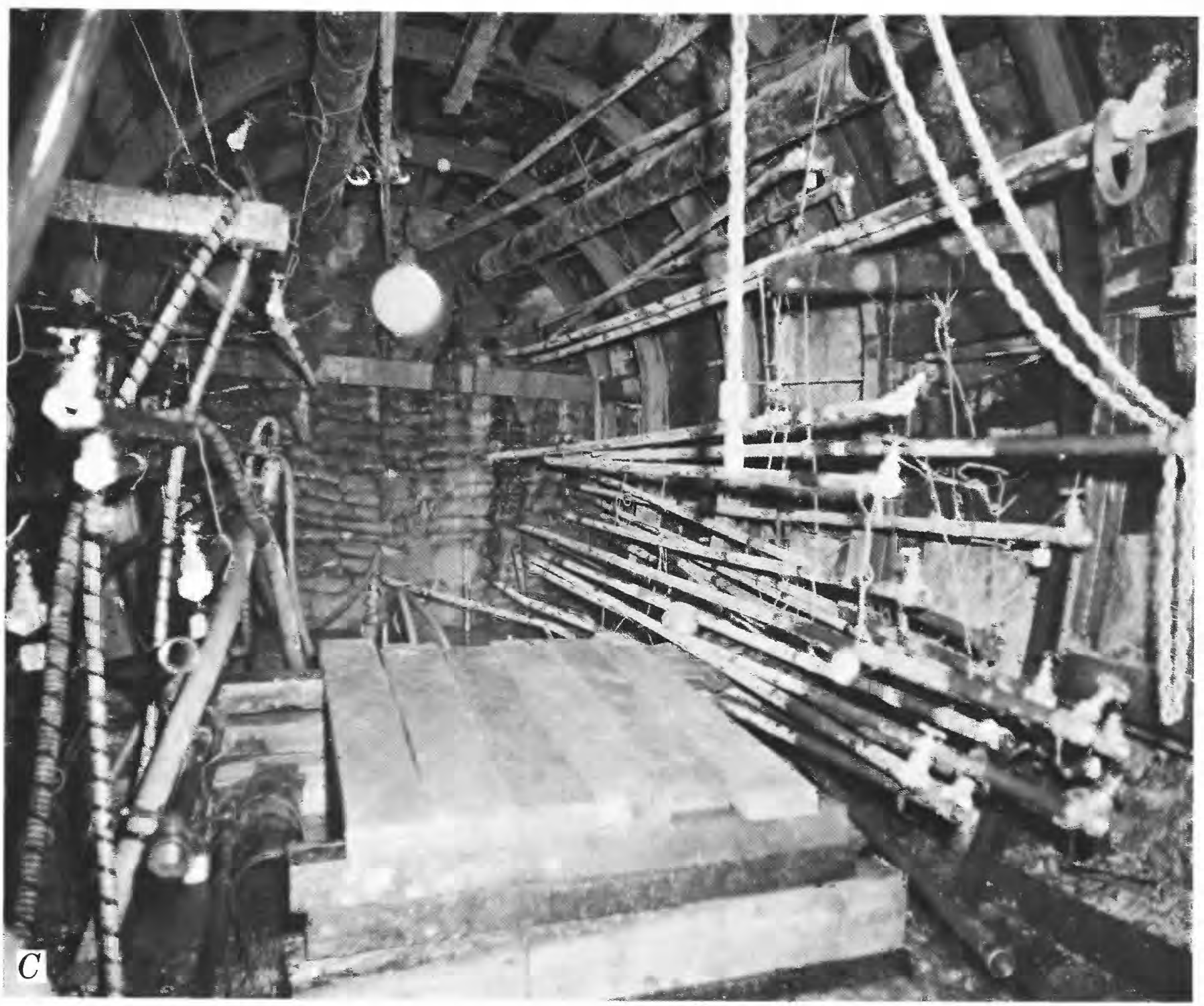

FIGURE 13.-Special engineering operations in sedimentary rocks of the Dakota Group, Roberts Tunnel. A, Water running from nipples placed in feeler holes in quartzite beds; heading at station $12+00$. B, Quartzite beds buckled by grout under excessive pressure; note deformed steel support; heading at station $45+01$. $C$, Inner bank of bulkhead; tunnel was filled with concrete to nipples of grout pipes before grouting was attempted; heading at station $38+65$. placed in two separate operations to form a smooth lining with a 10.25 -foot circular cross section. An $80^{\circ}$ section of the lining was first placed on the tunnel floor as an "invert" section by means of steel forms specially fabricated for the purpose. Later, arch forms were used to place the remaining $280^{\circ}$ section.

Concrete placed in the tunnel between the West Portal and station $180+00$ was prepared with Type I, Class " $A$ " cement, except for short sections between stations $14+68$ and $16+05$, stations $37+24$ and $46+65$ and stations $178+50$ and $180+00$, where sulfate resistant Type $\mathrm{V}$ cement was used. A resin-based airentraining agent "Protex" and a water-reducing admixture (calcium lignon sulfonate) were added to concrete mixtures used in the entire section. Compressive strengths measured on 6-inch and 12 inch test cylinders at the end of a 28-day period all exceeded 3,000 psi.

\section{PROGRESS}

Advance of the tunnel heading and other operations were reported to the Board of Water Commissioners twice a month. Report periods extended from the 1st to 15 th day and from the 16th to the last day of each month. Plates 1,6 , and 7 show 
how the rate of advance of the tunnel heading was related to the geology and gives an accurate measure of the difficulty of the tunneling operation for all sections of the tunnel between the West Portal and station $180+00$. Progress for each report period is compared graphically with average progress for 1957 and 1958, with the total average progress of the West Portal heading, and with the total average progress of all four headings of the tunnel. Poor progress correlates with sections of the tunnel requiring heavy support or extensive grouting because of faulting and jointing of the rocks or because of heavy waterflows into the tunnel through open fractures associated with strong faults.

\section{OCCURRENCE OF NATURAL GAS}

Combustible gas issuing from fractures in the black carbonaceous shaly limestones and limy shales was first noticed near station $72+50$. Investigations were made by the Colorado Bureau of Mines. Air samples were taken from various portions of the tunnel and yielded methane contents from 0.05 to 0.17 percent in the tunnel air and 3.2 percent in a sample taken directly from a fissure. Continued testing as the tunnel heading was advanced indicated that no gas was entering the tunnel beyond station $115+00$. Precautions were taken to insure adequate ventilation and to prevent electric spark ignition of the gas, in case dangerous accumulations resulted from failure of the ventilating system.

\section{GEOLOGY OF THE EMERGENCY GATE SHAFT}

An emergency gate shaft was excavated at station $14+40$ from a collar elevation of 9,052 feet to tunnel level to provide means for shutting off waterflow though the tunnel for required periodic inspections. The collar of the shaft is in black, fissile Benton Shale (fig. 7). At depth, the shaft encountered a sill of felsite porphyry and sandstones, quartzites, and black shales of the Dakota Group (fig. 14).

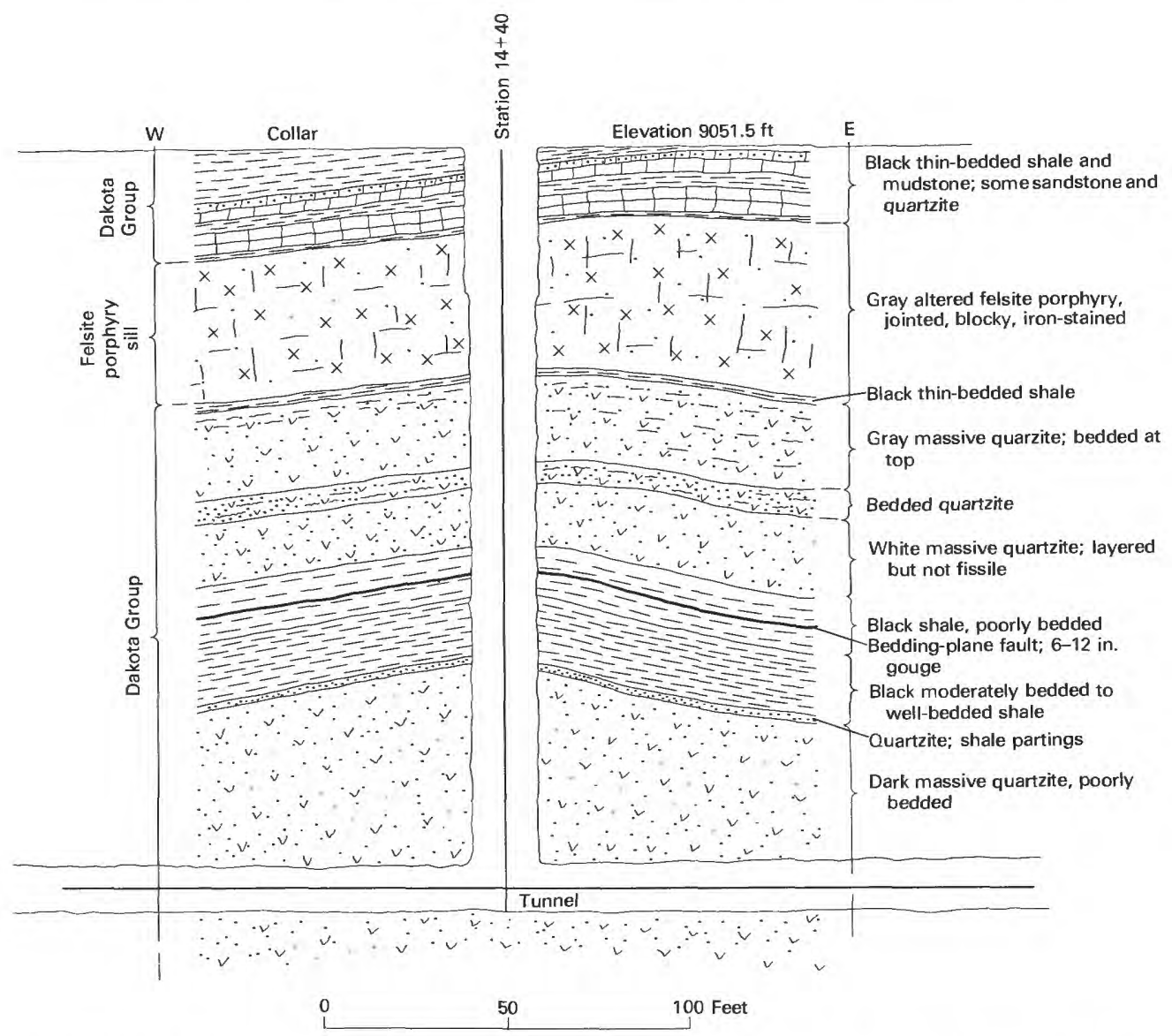

FIGURE 14.-Geologic section of the emergency gate shaft, station $14+40$, Roberts Tunnel. Figure 7 is a photograph of this location. Geology by V.Q. Hornback, 1957. 


\section{Stations $180+00$ to $291+60$, Williams Range Thrust Plate}

\section{GEOLOGY}

The tunnel in the segment of the Roberts Tunnel between stations $180+00$ and $291+60(\mathrm{pl} .1)$, a distance of 2.1 miles, was driven from two headings: one from the West Portal adit, and the other from an access shaft at station $459+43.64$ (p. C57). At station $180+00$, the heading, as it was advanced from the West Portal, passed from the Pierre Shale (p. C5) through the northeast-dipping Williams Range thrust fault and into complexly fractured and altered Precambrian rocks above the fault and continued through these rocks to a "hole through" with the heading advanced from the access shaft at station $281+58$. The heading driven westward from the access shaft intersected the Williams Range thrust fault, which dips to the west, at station $291+60$ after passing through a succession of brittle black shales metamorphosed by heat from the Montezuma stock and lying below and southeast of the fault (p. C36).

\section{ROCK UNITS}

PRECAMBRIAN ROCKS

Development of the Williams Range thrust fault resulted in pervasive shearing, shattering, and alteration of the Precambrian rocks in the plate above the fault. At tunnel level, mylonitization destroyed or greatly modified original fabrics of the rocks. Surface exposures are almost completely buried by a blanket of glacial-fluvial and recent stream deposits (pl. 1, stas. $164+00$ to $305+50$ ). In only a few short sections of the tunnel, in small areas of surface outcrops, and from cores of exploratory drill holes from the surface was it possible to estimate the fabric and mineralogy of the rocks before they were altered and mylonitized. East of station $180+00$ to the vicinity of station $195+00$, a contorted succession of extensively fractured layers of biotite gneiss, which contains generally concordant lenses and layers of pegmatite and aplite, is exposed in the tunnel. Beyond station $195+00$, mylonite, which locally contains small bodies of unsheared gneiss and aplite, extends to a very strong fault at station $273+20$. Between this fault and the Williams Range thrust fault at station $291+60$, the tunnel exposed gneissic aplite, biotite gneiss, biotite schist, and a few thin layers of quartzite and hornblende gneiss. Pegmatite and aplite bodies, which show sharp contacts with adjacent rocks, are scarce; but where present they are generally conformable with the layering of the metamorphic rocks.

Rocks from core holes drilled from the surface to tunnel level (pl. 1, between stas. $164+00$ and $305+50$ ) consist dominantly of aplite, gneissic aplite, gneiss, and thin layers or lenses of pegmatite, quartzite, and hornblende gneiss. In all core holes the intensity of mylonitization of the rocks increases with depth; as a result, the original fabric of the rocks has been largely obscured.

APLITE AND PEGMATITE

Sugary aplite is very abundant in the tunnel and in exploratory drill holes. It consists of quartz, microcline, and oligoclase in a mosaic aggregate of grains which have an average size of no more than $1 \mathrm{~mm}$ (millimeter). A few biotite flakes are present, and in some samples clusters of quartz grains show sutured contacts. Locally, the aplite grades into coarser grained pegmatitic or gneissic aggregates of quartz and feldspar or into layers of biotite-rich gneiss or hornblende gneiss. Some aplite grades into rocks that are coarse-grained enough to have the aspect of alaskite, a medium-grained leucocratic granitic rock.

A few bodies of pegmatite, which were intersected in core holes and in the tunnel, contain crystals of quartz and microcline to as much as several inches in diameter.

\section{BIOTITE GNEISS}

The biotite gneiss contains up to about 15 percent biotite in parallel to subparallel orientation in an aggregate of fine- to medium-grained quartz, oligoclase, and orthoclase or microcline. Apatite and rounded zircon crystals are minor accessories. The gneiss has many fabric varieties. Some exposures show biotite-rich layers that alternate with alaskitic layers, which are nearly devoid of dark minerals. Other exposures are inconspicuously layered and the gneissoid aspect of the rock results from alteration of thick quartz-rich and feldspar-rich layers and thin biotite-rich layers. Both quartz and feldspar form lenticules in some fabric varieties, and where biotite is moderately abundant, the rock is an augen gneiss.

The small amounts of potassium feldspar in the biotite gneiss is noteworthy. The dominant feldspar is oligoclase, except in thin layers of aplite in conspicuously layered varieties of the gneiss. Biotite 
gneiss in the tunnel between stations $180+00$ and $195+00$ contains some muscovite in parallel growth with the biotite.

HORNBLENDE GNEISS

The hornblende gneiss consists of abundant hornblende, plagioclase-ranging from oligoclase to andesine in composition-quartz, and minor biotite. The hornblende is strongly pleochroic in greens and browns in most samples, but a few samples contain a hornblende of pale colors in thin section, which appears to be iron deficient as compared with the more strongly colored varieties.

The hornblende gneiss has a considerable range of mineral composition and fabric. Layers that consist almost entirely of hornblende crystals in parallel orientation grade into layers that contain more randomly disposed, larger crystals in a medium- to coarse-grained aggregate of tabular plagioclase grains and more or less granular quartz. Some exposures contain sparse, generally subparallel, biotite flakes.

\section{QUARTZITE}

A few thin layers of glassy, brittle quartzite are associated with the biotite gneiss or alternate with layers of aplite. The quartz grains are sutured or have mosaic contacts. Feldspar, either microcline or oligoclase or both, is present in different amounts.

TERTIARY ROCKS

FELSITE PORPHYRY

A flat-lying felsite porphyry dike was intersected by the tunnel between stations $257+80$ and $259+10$ and by drill hole 6 (pl. 1). The rock is thoroughly altered and contains numerous tiny veinlets of calcite. Phenocrysts of plagioclase 1-2 mm long are almost completely converted to sericite. Equant feldspars in a microcrystalline groundmass are equally altered. Scattered phenocrysts of quartz are embayed by resorption, and euhedral biotite crystals have been completed altered to chlorite.

In the tunnel exposures, the felsite porphyry is closely jointed and blocky and is a dull gray to greenish gray. Faults that intersect the dike are filled with sticky gouge.

\section{BRECCIA AND MYLONITE}

Breccia and mylonite are conspicuous throughout most of the tunnel section and in drill cores from the Precambrian rock above the Williams Range thrust fault. Some of the crushed rocks are uncemented or have a clay matrix and caved freely into the tunnel when they were exposed. Elsewhere, quartz cement, which contains sparse clay minerals and chlorite, has produced a glassy, brittle rock that superficially resembles quartzite but after examination under the microscope the rock was determined to be a mylonite (fig. 15).

Many bodies of breccia and mylonite are tabular, others are irregular in outline. Although some of the crushed zones are confined between sharp walls and have resulted from pulverization of rocks along or within faults, other masses have gradational boundaries and seem to have developed by uneven mass movement of thoroughly disrupted, almost sandy aggregates of crushed mineral and rock grains. Although the breccia and mylonite bodies have a variety of shapes and attitudes, several tabular bodies have flat dips. In spite of extreme crushing, ghostlike original structures, such as foliation in the metamorphic rocks, can still be seen in some of the breccias and mylonites. In the mylonites, original foliation is intersected by poorly defined gneissoid fabric or streakiness, which is parallel to the direction of shear movement and the dislocation of the crushed aggregates.

Quartz and feldspars in the breccias and mylonites generally behaved as brittle substances and were ruptured into angular fragments (figs. 15A, 15B). Quartz was complexly fractured and in part was recrystallized; the quartz also shows irregular mosaic patterns or mortar structure with extreme development of undulatory extinction. Some fragments are flat or elongate, and in the mylonites the fragments are in subparallel arrangements. Plagioclase broke across crystals and along cleavages. Some plagioclase grains show twinning developed by deformation; other grains were complexly deformed by rupture combined with bending and solidstate dislocations within single crystals or aggregates (fig. 15C). Biotite, now largely altered to chlorite, was shredded and dragged along with and molded around other more brittle minerals, and commonly it is bent in ragged sheets or plates which are concentrated along microshears (fig. 15D).

Most of the brecciation and mylonitization resulted from dislocations during formation of the Williams Range thrust fault; therefore, fracturing of the rocks is considered to be of Tertiary age. Later breccias are associated with steep faults. Breccia in a steep fault that intersects and offsets the Williams Range thrust fault near station $180+00$ consists of angular to rounded fragments from microscopic size to several feet in width (pls. 7,8 ). Large and small fragments in the breccia are themselves brecciated and cemented by glassy quartz. 

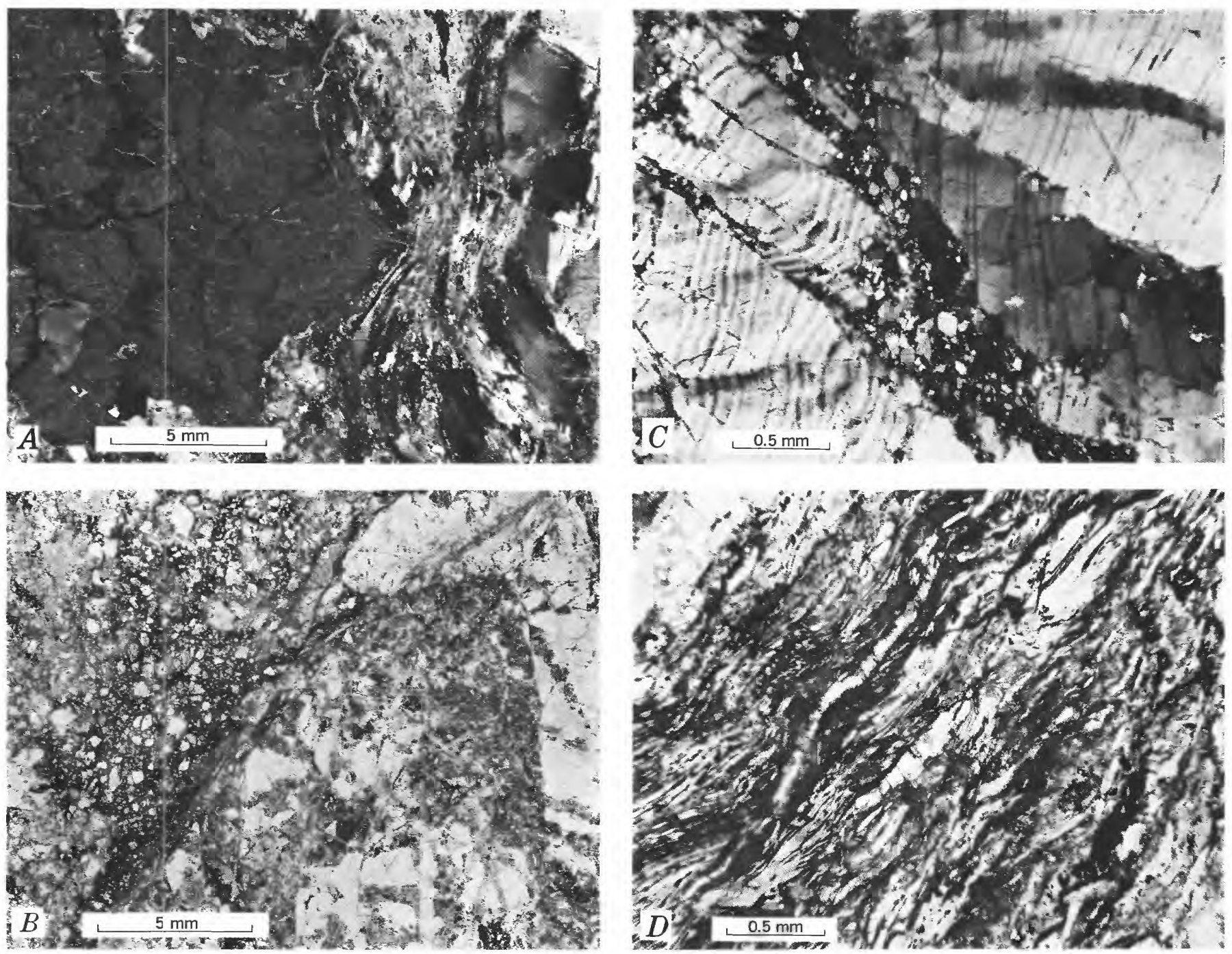

FIGURE 15.-Photomicrographs of mylonites, Roberts Tunnel.

$A$, Sheared and crushed quartz adjacent to large grain of plagioclase in mylonite. Diamond drill hole 6, depth 368 feet. Crossed polars.

$B$, Breccia cemented by pyrite (black and fine-grained silica. Station 210+00. Plain light.

\section{STRUCTURE}

The driving of the Roberts Tunnel afforded an unusual opportunity to observe a thrust fault and the structure in the plate of a thrust fault in three dimensions, and to establish the relations, if any, between the preexisting structures-such as the foliation in the Precambrian rocks, the development of the thrust, and any prethrust or postthrust faulting and jointing.

\section{FOLIATION}

The foliation in the layered Precambrian metamorphic rocks in the plate above the Williams Range

$C$, Crushed and bent plagioclase in mylonite from station 257+00. Crossed polars.

$D$, Sheared chloritized biotite along microshear in mylonitic biotite gneiss. Drill hole C, depth 370 feet. Plain light.

thrust fault is complicated by numerous small folds, but extensive mylonitization and alteration, especially between stations $195+00$ and $273+20$, have largely obliterated structural details so as to make their mapping in the tunnel impractical. However, it was possible to measure a sufficient number of foliation planes to demonstrate that the layering in the rocks generally strikes north and northwest, and through most of this section of the tunnel, foliation dips to the east and northeast. Near the eastern exposures of the thrust plate in the tunnel, the gneisses and schists are folded into a succession of small anticlines and synclines. Correlation of structural features in the layered metamorphic rocks 
at tunnel level with those structures in rocks at the surface is difficult because of a thick cover of alluvium, but some information regarding rock types and the structural features above tunnel level was obtained from a few surface outcrops and from core holes drilled from the surface. The attitudes of foliation planes between stations $180+00$ and $291+60$ are indicated in contoured equal-area plots on plate 1.

\section{FAULTS}

The Precambrian rocks between stations $180+00$ and $291+60$, in the Williams Range thrust plate, were subjected to tectonic forces during Precambrian time, probably during the uplift of the Ancestrial Rockies in Pennsylvanian and Permian time, during the Laramide orogeny (when the Williams Range thrust fault developed), and during subsequent uplift of the Front Range. The identification of structures related to the different periods of tectonic activity, particularly prior to the Laramide period of orogeny, are difficult because there was reactivation of older structures, such as faults, during the Laramide orogeny. Limited surface exposures (Robinson and others, 1974) restricted observations at the surface. Although a tunnel has 100 percent exposures, a tunnel is essentially a two-dimensional exposure, and the trend of major structures cannot always be recognized. An example of this is the Frey Gulch shear zone, which was identified at the surface, (Robinson and others, 1974, p. B32) but was not identified as a specific zone in the tunnel.

The following discussion is based on the observations made during the mapping in the tunnel.

\section{WILLIAMS RANGE THRUST FAULT}

The Williams Range thrust fault can be traced from a point about 5 miles east of Breckenridge, in a northwesterly direction (approximately N. $35^{\circ} \mathrm{W}$.), for a distance of at least 50 miles into Middle Park, north of Kremmling, Colo. The fault has caused superposition of Precambrian igneous and metamorphic rocks on Cretaceous sedimentary rocks. In most localities, Pierre Shale is exposed just below the fault, but Lovering (1935, p. 47) noted that near the southern terminus of the fault Precambrian rocks abut against shales of the Niobrara Formation and quartzites of the Dakota Group. Exposures of the fault generally are concealed by overburden. The schists, gneisses, and granites in the plate above the fault are highly fractured for a considerable distance northeast of the surface trace of the fault, and much of the topography in a wide zone that parallels the trace of the fault on the northeast side is smooth and rolling. Bedrock exposures of unfractured Precambrian rocks are practically nonexistent immediately above the fault. The relation between the surface trace of the fault and the topography indicates that the dip of the fault changes considerably from place to place, but that for most of its length the dip is about $30^{\circ}$ to the northeast. Locally, the fault plane is folded, but it is not known whether the folding represents corrugations formed at the time of faulting or is a result of later deformations. Numerous steep faults intersect and displace the thrust-fault surface. Some of these may be tear faults that were formed at the time of thrusting, but many are younger.

The thrust fault was intersected twice in the Roberts Tunnel at points 2.1 miles apart (pls. 1, $7 C$, $8 A, 9 B$ ). At station $180+00$ the fault has a usual attitude, striking north to northwest and dipping about $30^{\circ}$ to the east, but the structure is complicated at tunnel level by a normal fault that dips about $60^{\circ}$ to the east and that offsets the thrust fault (fig. 16). The normal fault brought Precambrian rocks into a steep contact with shale and prevented direct observation of the thrust fault at tunnel level. A strong, flat shear zone in the shale west of the normal fault, however, marks the bottom of concentrated shear movement along the thrust fault and indicates that shearing along the thrust fault extended for at least 120 feet into the shale below and normal to the contact of Precambrian rocks with the shale. The normal fault contains a breccia of rock fragments, which were formed by movement along the thrust fault.

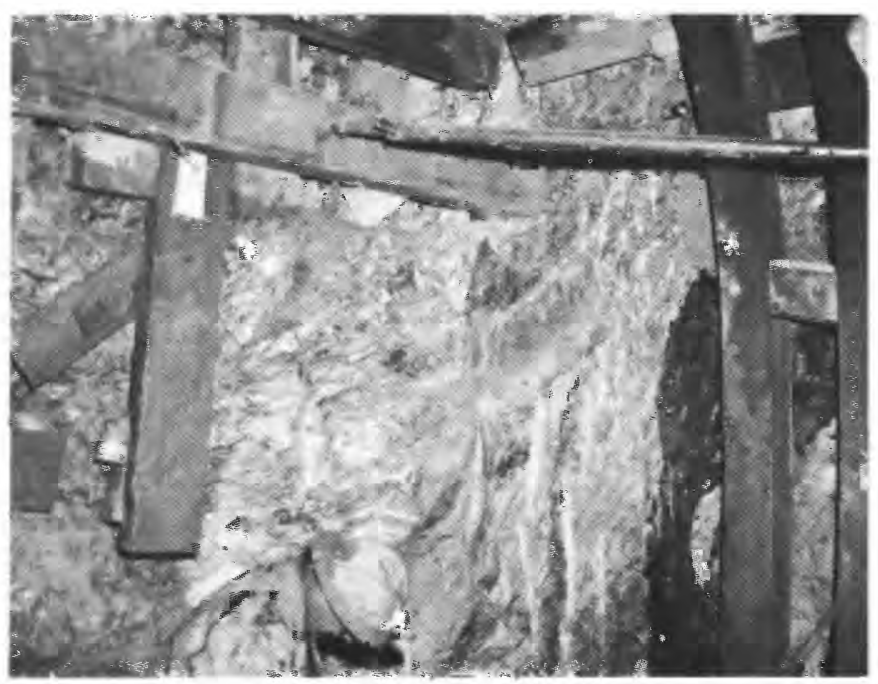

Figure 16.-Right rib and face near station $180+00$ showing mixture of sheared, altered gneiss and Pierre Shale (black) in a steep fault that intersects the Williams Range thrust fault. 
At station $291+60$ the tunnel again crosses the thrust fault; there, Precambrian gneiss abuts against highly fractured, brittle, baked shale; and the fault strikes northeast and dips about $30^{\circ}$ to the northwest. Thus, the fault plane between stations $180+00$ and $291+60$ forms a broad syncline which has a north-plunging axis.

\section{OTHER FAULTS AND JOINTS}

In the Precambrian rocks above the thrust fault between stations $180+00$ and $291+60$ (a distance of 11,160 feet in the tunnel), 1,037 faults were mapped with an average spacing of 10.76 feet. Variations in the attitudes of these faults are indicated in plots of their poles in figure $17 \mathrm{~A}$. Some of the faults are tight shears with slight displacement, but others are wide zones of breccia which contain innumerable small slip surfaces, gouge, and hydrothermally altered argillic and chloritic masses. For statistical analysis of the attitudes of the faults, the interval between stations $180+00$ and $291+60$ was divided into three sections and the poles of the fault planes in each section were plotted with a Schmidt equal-area net and then contoured (pl. 1) with a 1-percent counter. A large diversity of attitudes of the fault planes is indicated by the fact that the maximum concentration on the contoured plots is only 6.1 percent and in the interval between stations $217+20$ and $254+40$ only 4.3 percent. Most of the faults have dips greater than $30^{\circ}$, and concentrations on the contoured plots correspond to dips of at least $60^{\circ}$.

Three strong faults between stations $208+00$ and $225+00$ dip flatly in the same general direction as the thrust fault at station $180+00$. The locations and attitudes of the flat faults suggest that they are related to the Williams Range thrust fault and that they are lesser shears in the Precambrian rocks above the plane along which the main movement was concentrated. Most of the other faults in this section of the tunnel, in common with the faults in the sedimentary rocks below and west of the thrust fault, bear no obvious geometrical relationship to the thrust fault, and the few direct observations that could be made suggest that the faults intersect and displace the thrust-fault surface. Locations of maxima in equal-area plots for faults in the sedimentary rocks west of the thrust fault and in the Precambrian rocks east of the fault are similar and suggest a genetic relationship of many of the steep faults above and below the thrust fault.

In the western part of the thrust plate, from station $180+00$ to station $217+20$, a 7.2 -percent maximum indicates a concentration of faults subparallel to the foliation, which is subparallel to the strike but not the dip of the Williams Range thrust fault. In the eastern part of the thrust plate, the eastward dip of the foliation flattens appreciably, and the thrust surface dips west. Here, the strongest fault maximum (6.1 percent) indicates a concentration of steep faults approximately normal to the thrust surface. A comparable situation is observed in the Benton and Niobrara rocks between stations $47+00$ and $92+00$ (p.C11).

Attempts to map joints in the thrust plate were abandoned. Joints are so numerous and are so intimately related to brecciation, mylonitization, and fault movement in wide zones and have such diverse attitudes that mapping, even on a scale of $1 \mathrm{inch}=50$ feet, was not attempted. A measure of the extent to which the rocks above the thrust fault are fractured is shown on plate 1 , where intervals of complexly fractured and altered rocks are indicated by a bar diagram set above the tunnel geologic plan. Between stations $180+00$ and $291+60,35.2$ percent of the length of the tunnel exposes rock that are thoroughly brecciated, shattered, and altered, most of which are associated with large faults or with concentrations of smaller faults.

Another indication of the extent to which the rocks above the thrust plane are fractured is the amount of water intersected in feeler holes drilled from the heading of the tunnel as it was advanced (pls. 1, 8,9). Ground-water flows were encountered in sufficient quantities to require efforts to seal them off with grout for 74.2 percent of the interval between stations $180+00$ and $291+60$. Flows of more than 200 gallons per minute from water-bearing fissures tested by drill holes were common and indicate widespread development of closely spaced, interconnecting fractures.

STRUCTURAL EVOLUTION OF THE WILLIAMS RANGE THRUST FAULT

Two major geologic events followed the cessation of Late Cretaceous deposition of a thick sequence of marine sediments: the development of the Williams Range thrust fault and later the intrusion of the Montezuma stock and its satellitic bodies. Both events caused displacements of the Earth's crust which were accompanied by development of intricate patterns of dislocations along faults of many attitudes and the formation of innumerable joints.

Figure $17 B$ is a histogram that shows the frequency distribution of faults of all magnitudes mapped in the interval between West Portal and station $468+49$ in the Roberts Tunnel. As would be expected, the maximum concentrations of faults are present in the intensely sheared Precambrian rocks in the plate above the Williams Range thrust fault; 

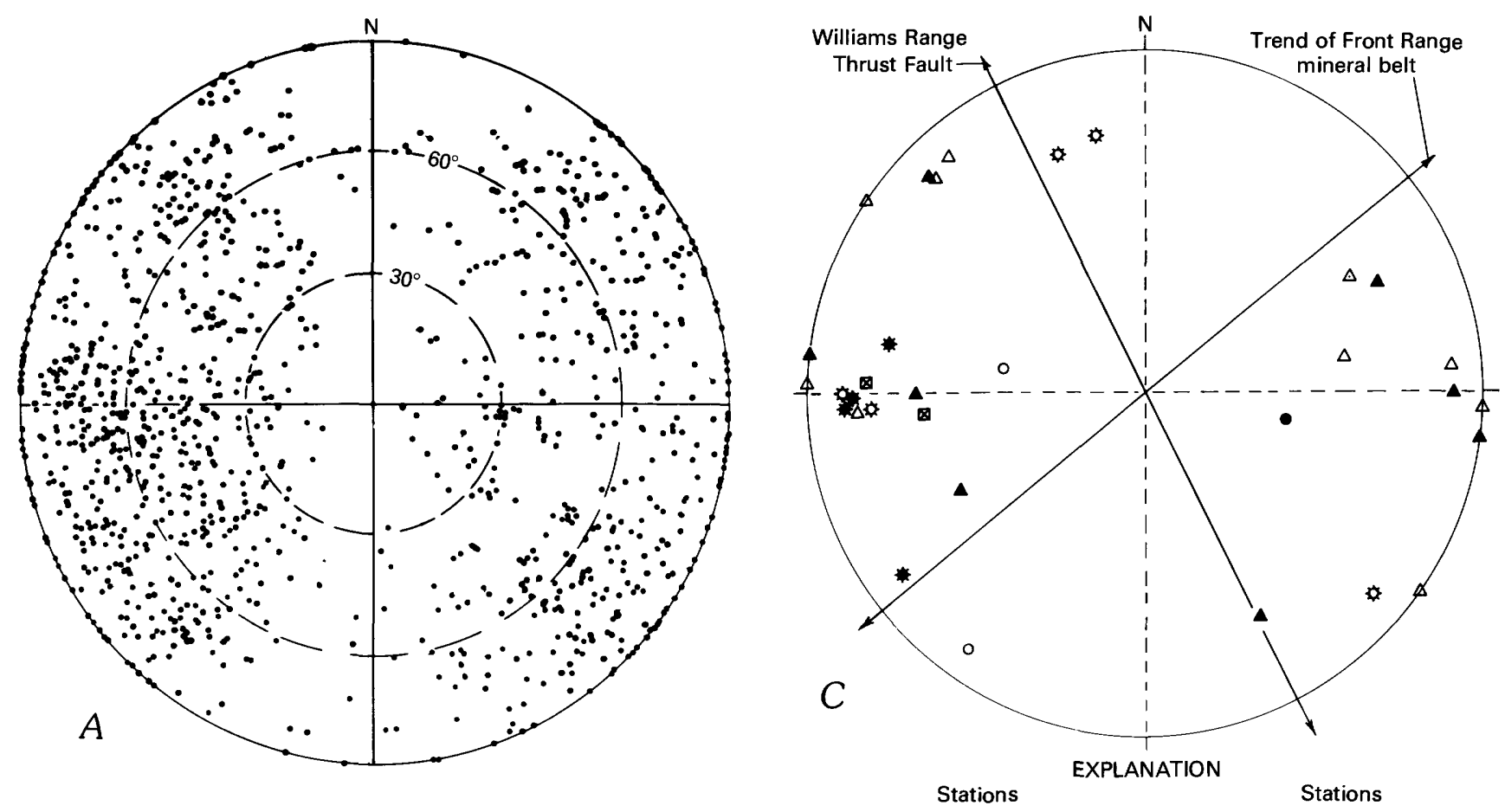

- FAULTS $-9+46$ to $180+00$ - FAULTS $-291+60$ to $343+00$ $\triangle$ JOINTS $-9+46$ to $180+00$ O JOINTS $-291+60$ to $343+00$ (aAULTS $-180+00$ to $291+60$ FAULTS $-343+00$ to $468+49$ JOINTS $-343+00$ to $468+49$

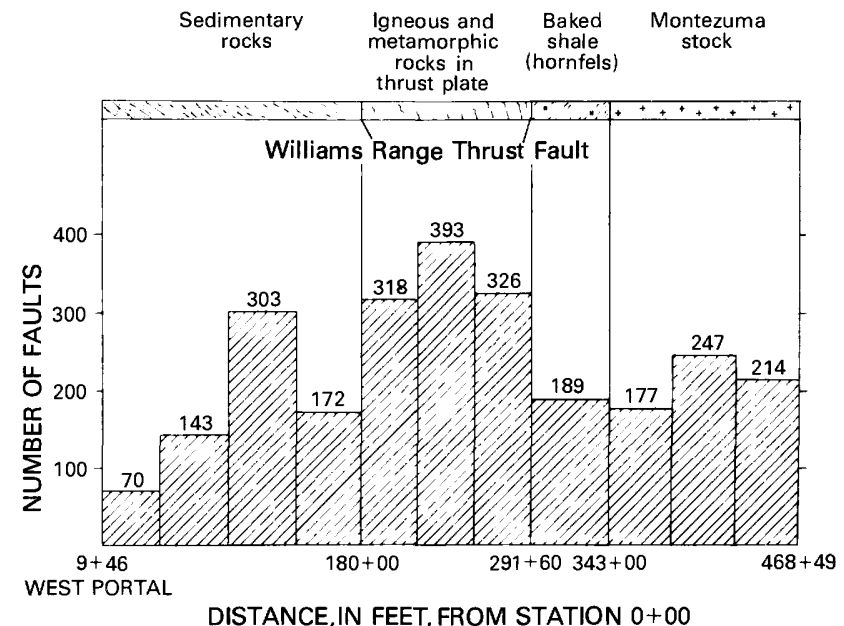

$B$

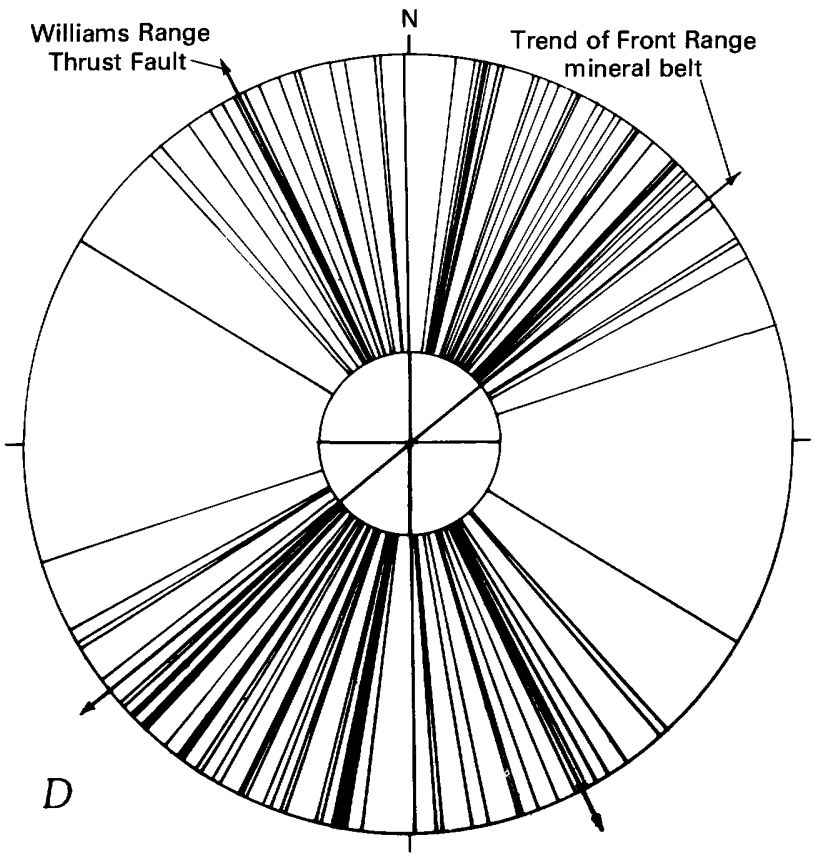

Figure 17.-Compilations of fault data for Roberts Tunnel, from

West Portal (sta. 9+46) to station $468+19$.

$A$, Equal-area plot (lower hemisphere) of poles of 1,037 faults between stations $180+00$ and $291+60.0-30^{\circ}, 5.5$ percent, $30^{\circ}-60^{\circ}, 32.4$ percent; $60^{\circ}-90^{\circ}, 62.1$ percent.

$B$, Histogram showing frequency distribution of faults between West Portal and station $468+49$.

$C$, Poles of fault and joint concentrations from equal-area plots between West Portal and station 468+49.

$D$, Radial plot of strikes of 53 faults exposed at the surface near west end of Roberts Tunnel. 
but a submaximum in the shales at a considerable distance below and west of the Williams Range thrust fault and extensive faulting in the Montezuma stock, which is younger that the thrust fault (Robinson and others, 1974, pl. 1), indicates that many faults, perhaps most of them, developed independently of the movements that caused the intrusion of the stock. Further substantiation of this conclusion is shown in figure $17 \mathrm{C}$, which shows plots of the poles of fault and joint concentrations in the four lithologic and structural units between West Portal and station $468+49$. The plots were made by projection from the lower hemisphere with the aid of an equal-area net. Concentrations of poles are remarkably similar in all the plots and very few poles correspond to the faults that reflect the attitude of the Williams Range thrust fault in Roberts Tunnel. Figure $17 D$ is a radial plot of the strikes of 53 faults in the vicinity of the west part of the Roberts Tunnel, which are shown on the geologic map of the Front Range (Lovering and Goddard, 1939). Poles of the faults were not plotted because surface exposures were too poor to allow accurate dip measurements. Comparison of figure $17 \mathrm{C}$ and figure $17 \mathrm{D}$ proves a similarity of strikes of faults in the tunnel and faults mapped at the surface in the same vicinity. Figure $17 D$ also shows the average trend of the mineral belt of the Front Range, a trend that conforms with that of some concentrations of fractures on the surface or underground as indicated in figure $17 C$.

Approximate parallelism of sets of fractures with the mineral belt is seen in a fault maximum of 8 percent in quartzite of the Dakota Group west of station $47+00$ (p. C11), a 12.7-percent maximum in Benton and Niobrara Formations between stations $47+00$ and $92+00$, an 8-percent joint maximum in Pierre Shale, a 4-percent joint maximum in baked shale (p. C40), and in concentrations of northeast joints in the Montezuma stock (p. C47).

Approximate parallelism of the trend of sets of steep fractures with the trace but not the dip of the Williams Range thrust fault is indicated in equalarea plots for several sections of the tunnel (pl. 1). Other trends correspond to strikes intermediate between those for the mineral belt and those for the Williams Range thrust fault. Noteworthy is the near absence of fractures of east-west strike.

Fault patterns in adjacent parts of the Front Range and the pattern in the vicinity of the west part of Roberts Tunnel are generally dissimilar. All data strongly suggest that most faults in the west part of the tunnel constitute a unique pattern, which is generated locally by dislocations at or near the intersection of the northeast-trending mineral belt and north- to northwest-trending, steeply dipping fractures that roughly parallel the axis of the Front Range and the surface trace of the Williams Range thrust fault. This intersection also is the location of the Montezuma stock and its underground extensions, and the complexity of the fracture pattern must have been increased by the emplacement of the stock.

The probable manner of development of the major geologic features along the west side of the Front Range in the vicinity of the Roberts Tunnel is indicated diagrammatically in figure 18 . Four stages are established so as to permit appraisal of the succession of major events that resulted in the evolution of the major structural features that are now observed in the area-minor folds and faults are omitted. The section shown for each stage is eastwest at a latitude of $39^{\circ} 36.2^{\prime}$ and was drawn so as to pass through the Montezuma stock at its present widest surface dimension. The Williams Range thrust fault is interpreted as having been developed as the result of gravity sliding.

A brief summary of the geologic events, condensed from a comprehensive discussion by Wahlstrom and Hornback (1962) follows:

Stage 1: Deposition of a succession of nonmarine and marine sedimentary rocks, which was followed by the beginnings of large-scale crustal dislocations and igneous activity.

Stage 2. Development of the Williams Range thrust fault, probably by gravity sliding, which may have resulted from intermittent vertical uplifts of large segments of bedrock northeast of the fault.

Stage 3. Intrusion of the Montezuma stock which caused local, forceful upward dislocation of parts of the thrust fault and superjacent rocks.

Stage 4. Tertiary and Pleistocene erosion. Additional uplifts and other dislocations, mainly along preexisting faults.

\section{ALTERATION}

The thoroughly sheared, crushed, and brecciated Precambrian rocks above the Williams Range thrust fault probably were altered somewhat by percolation of waters of surface origin during the development of the fault. Except for deposition of silica cement in some of the shattered rocks, alterations during thrust-fault development have been obliterated by 


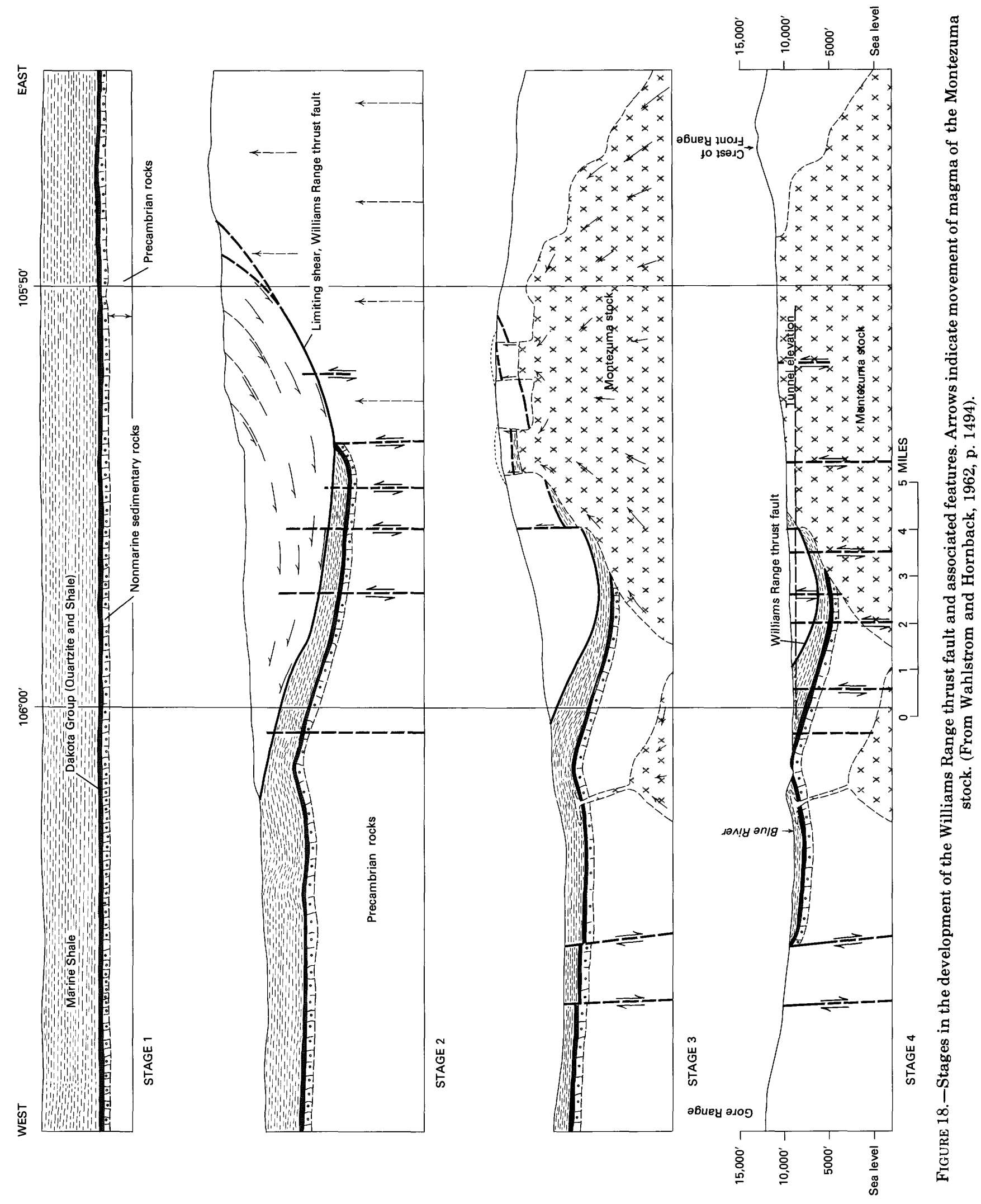


hydrothermal alteration accompanying and following the emplacement of the Montezuma stock. Alteration is especially concentrated along steep faults that intersect the thrust fault and has spread out in adjacent brecciated rocks to produce bleached, clayey materials that have created hazardous tunneling conditions. Silicification, argillization, chloritization, and epidotization have been pervasive and fractures have been sparsely mineralized with carbonates, drusy quartz, fluorite, pyrite, and hematite.

Samples were collected from gouge and soft, altered wallrocks that are associated with several major faults between stations $180+00$ and $291+60$. All samples were altered sufficiently so that they disintegrated spontaneously when placed in water. After disintegration, the samples were stirred vigorously; the supernatant fluid suspension was poured off; they were air dried at $89^{\circ} \mathrm{C}$; and the resulting powder was passed through a 200 -mesh screen. The minus 290 -mesh ( -74 micron) material was then examined by X-ray diffractometer, differential thermal, and staining techniques to determine the mineral composition. Table 2 summarizes the mineralogy of the fault gouge and intensely altered wallrocks for representative samples. Estimates of relative abundance of individual constituents are based on heights of peaks on diffractometer tracings and on optical examination of stained preparations.
Generally, sharp peaks on X-ray diffractometer tracings and on staining tests indicate that most of the clay minerals form well-crystallized aggregates. For a few samples, broader diffractometer peaks and examinations in thin section indicate limited development of mixed-layer clays in which montmorillonite layers are intergrown with layers of muscovite or chlorite. Although some chlorite is present in or near faults, much more has formed by alteration of biotite or hornblende present in the rocks before faulting and alteration. Montmorillonite and kaolinite are abundant in most samples and formed mainly at the expense of feldspars, especially plagioclase.

Erratic distribution of the clay minerals in the faults and in the adjacent altered wallrocks is evident from data in table 2. Gouge in several faults was formed by the crushing of previously argillized rocks, and in other faults the gouge itself was altered. Movements along the faults probably continued intermittently prior to, during, and after claymineral formation, and altering solutions probably followed different channels at different times. The composition of wallrocks interesected by the faults and accompanying fractures also probably determined in part which clay minerals formed and contributed to variations in clay content from sample to sample.

Sericite (2M muscovite) in fault gouge and near faults is very fine grained. At a distance from the

TABLE 2.-Mineral composition of gouge and altered wallrocks between stations $180+00$ and $291+60$

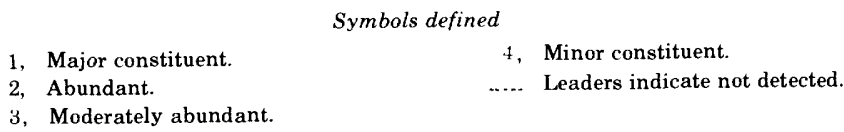

\begin{tabular}{|c|c|c|c|c|c|c|c|c|}
\hline Station & $\begin{array}{l}\text { Strike and } \\
\text { dip of fault }\end{array}$ & Sericite & $\begin{array}{l}\text { Montmoril- } \\
\text { lonite }\end{array}$ & Chlorite & Kaolinite & Quartz & K-feldspar & Plagioclase \\
\hline $199+95$ & N. $17^{\circ}$ W. $53^{\circ}$ NE. & 2 & 3 & -.-- & -... & 3 & -..- & 3 \\
\hline $216+52$ & N. $52^{\circ}$ E., $22^{\circ} \mathrm{SE}$. & 4 & 4 & --- & 3 & 1 & 4 & 4 \\
\hline $226+67$ & N. $20^{\circ}$ E., $22^{\circ}$ NW. & --- & 4 & --- & 3 & 1 & $-\cdots$ & 3 \\
\hline $230+00$ & N. $24^{\circ}$ W., $52^{\circ} \mathrm{NE}$. & $\cdots$ & 2 & 2 & --- & 3 & $\cdots$ & 4 \\
\hline $231+44$ & N. $11^{\circ} \mathrm{W} ., 79^{\circ} \mathrm{NE}$. & $-\cdots$ & 1 & $\cdots$ & 2 & 3 & 4 & --- \\
\hline $235+00$ & N. $40^{\circ}$ E., $74^{\circ} \mathrm{SE}$. & -..- & 2 & 3 & 3 & 4 & $-\cdots$ & 1 \\
\hline $237+20$ & N. $36^{\circ}$ E., $60^{\circ}$ NW. & $-\cdots$ & 3 & 3 & $\cdots$ & 1 & $-\cdots$ & 3 \\
\hline $265+75$ & N. $43^{\circ}$ E., $64^{\circ} \mathrm{SE}$ & --- & 1 & $\cdots$ & $\cdots$ & 1 & 3 & 3 \\
\hline $273+00$ & N. $9^{\circ} \mathrm{W} ., 57^{\circ} \mathrm{NE}$. & $\cdots$ & 3 & ---- & 2 & $+\ldots$ & 2 & 2 \\
\hline $275+84$ & N. $25^{\circ} \mathrm{W} ., 72^{\circ} \mathrm{NE}$. & ---- & 2 & $\cdots$ & 3 & $\cdots$ & --- & 3 \\
\hline $287+25$ & N. $50^{\circ}$ E., $22^{\circ} \mathrm{SE}$. & $\cdots$ & 2 & $\cdots$ & 1 & 3 & $\cdots$ & $-\cdots$ \\
\hline
\end{tabular}


faults larger flakes of a sericite replace plagioclase feldspar. In aggregates that contain plagioclase and microcline, the microcline has been only slightly sericitized if at all.

Epidote commonly is associated with pale-green chlorite and has been formed by the alteration of hornblende, especially in hornblende gneiss. Zoisite, of abnormal blue interference colors, forms separate grains in quartz aggregates and was formed from iron-poor hornblende or from the calcic plagioclase in the hornblende-rich rocks.

\section{ENGINEERING PRACTICES IN RELATION TO GEOLOGY}

During construction of a tunnel, the engineering practices are directly related to the geologic conditions. Such factors as the amount of overbreak, the need for feeler holes to detect ground water or to detect poor ground in advance of the heading-and the resulting necessity for grouting-support requirements, and progress are related to the amount of fracturing, to the apparent attitude of fracturing, to the presence or absence of fault gouge, and to the amount of alteration and the type of alteration products. A summary of the engineering practices is shown graphically with the geologic plan and section for this interval of the tunnel on plate 1 (stas. $174+00$ to $305+50$ ).

\section{OVERBREAK}

Overbreak in the shattered metamorphic rocks, aplite, and mylonite in the interval between stations $180+00$ and $291+60$ is related to the attitudes of foliation planes and the intersecting fractures. Graphical analyses of overbreak were made in the same manner as for the bedded sedimentary rocks between West Portal and station 180+00 (p. C14). Because of the difficulty of supporting the badly broken rock in the thrust plate with the 6-inch steel sets shown in the specification drawings, sets of a new design were put into use beyond station $208+44$. The "new" steel sets, as compared with the "old" sets, were fabricated of either 6-inch or 8-inch $\mathrm{H}$ steel stock as required and were designed as slightly a arched section rather than as a circular section above the spring line. The relative dimensions of "old" and "new" 6-inch steel sets are shown in figure 19. Redesign of the steel modified the configuration of the payline area only slightly, and for purposes of comparison the outlines of the payline area above the spring line for both "old" and "new" steel supported sections can be regarded as the same.

The amount of overbreak was determined only where the rocks were sufficiently competent to permit measurement of sections. Use of timber crownbars extending to the heading from the top of the closest steel set and installed as soon as possible after blasting prevented continued caving or raveling of the tunnel arch in moderately fractured sections. Accordingly, the sections generally represent the immediate effects of blasting and do not indicate the extent to which the tunnel would develop a selfsupporting arch, if the rock were left unsupported. In a few places, an arch formed in the tunnel roof immediately after blasting, but in most places irregularities in the roof formed as a result of breaking to foliation planes or fractures during the blasting operation.

In several sections of the tunnel very heavy and incompetent rock was encountered creating great difficulty in the advance of the heading. In such sections, extensive use was made of steel spiling, breast boards, and top headings; explosives were used sparingly or not at all. The tendency of the roof and wallrocks to cave or squeeze into the tunnel prevented measurement of these tunnel sections.

Plate $4 A$ shows overbreak in an interval of steeply dipping layers of biotite gneiss and schist, which strike almost at right angles to the tunnel and that dip away from the tunnel heading. Overbreak resulted from the necessity of using large explosive charges to break the metamorphic rocks across their layering, but the break was not notably elliptical. The shattering effects of the explosives contributed to some splitting along foliation planes, and the combination of all factors resulted in the large arithmetic mean of 20.6 percent of ovebreak for 15 sections between stations $186+46$ and $187+86$.

Plate $4 B$ summarizes overbreak in 15 sections from station $212+55$ to station $213+95$. This interval of the tunnel exposed brittle mylonite intersected by several tight shears. Jointing is not conspicuous and the rock behaved as a virtually isotropic medium, except where intersected by the fractures. (Fractures are here defined as small faults or strong joints.) The characteristic of the rock to split to a fracture during the blasting operation produced a slight ellipticity with the longer axis of the ellipse normal to the apparent dip of the fractures in the tunnel heading.

Plate $4 C$ illustrates overbreak between stations 


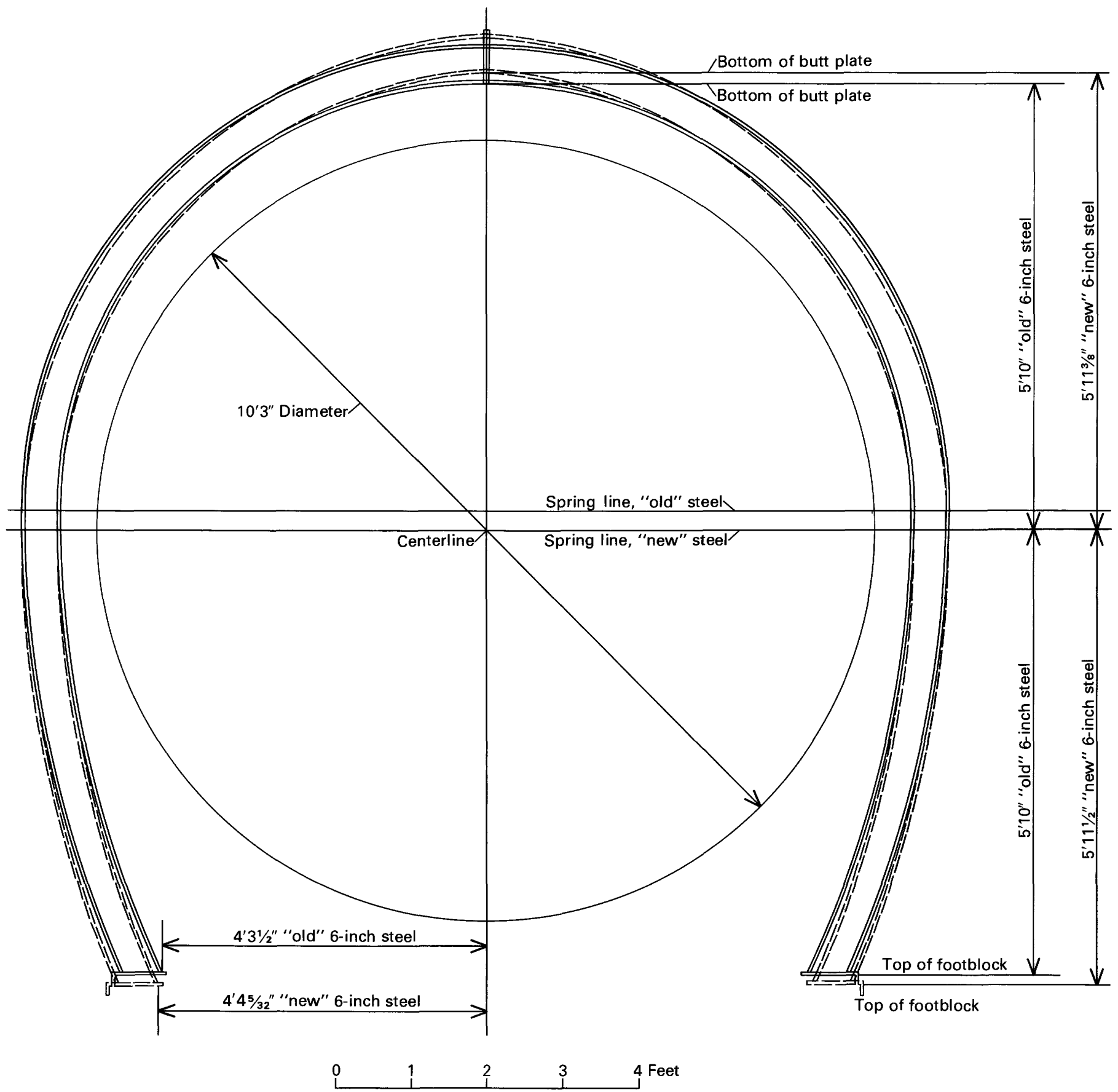

Figure 19.-Dimensions of "old" and "new" 6-inch steel sets, Roberts Tunnel.

$245+20$ and $246+60$. The rock in this interval of tunnel is a brittle, quartzose mylonite intersected by a conjugate system of tight slips and joints. Minimum support with 6-inch steel supports on 5-foot centers was required, and the mean overbreak was only 11.7 percent.
The interval of the tunnel shown on plate $4 D$ was driven through highly sheared, wet, altered biotite gneiss on the hanging wall of a strong fault at station $273+20$ and required use of 8 -inch steel sets with struts. The mean overbreak of 13.4 percent is not large considering the tendency of the faulted 
rocks to cave into the tunnel and, in some places, to develop an arch by slumping in the roof, as at station $273+50$. Average overbreak was reduced by placing heavy steel sets as close to the heading as possible and by using large quantities of crownbars and blocking above the steel sets as the heading was slowly and carefully advanced.

Plate $4 E$ indicates the nature of overbreak in a biotite gneiss and schist between stations $277+50$ and $278+90$. The rocks are intersected by a few tight shears and are relatively competent. Although the gneisses tended to split along layering during blasting, ellipticity did not develop in sections because of the steep dip of the layering. A mean overbreak of 15.1 percent resulted from the large explosive charges that were used to break the gneiss across the layering.

\section{FEELER HOLES, GROUND WATER, GROUTING, SUPPORTS, AND PROGRESS}

Plate 1 includes a graphical analysis of feeler hole exploration, location and amounts of water intersected in the feeler holes, the amount of grout used in an attempt to seal off the water, the type and location of supports, and progress. Plates $8,9 A$, and $9 B$ and figure 20 show the same aspects of the tunneling operation on a larger scale and permit detailed correlation with the geology in plan and section for a variety of conditions encountered in the tunnel.

Plate $8 A$ shows the relationships in the pervasively sheared and altered Precambrian gneisses above and east of the Williams Range thrust fault. The faults generally are filled with gouge, and the wallrocks are extensively altered to soft, clayey materials. The rocks in this tunnel interval proved to be relatively impermeable to movement and penetrations by underground water; except for flows near station $180+00$, water was encountered in only small amounts-insufficient to require grouting. Maximum use of 6-inch steel supports with struts and timber lagging was required to support heavy, swelling, and squeezing ground, which contains abundant gouge and clay minerals. Almost 2 months were spent in advancing the tunnel heading 750 feet, a rate of progress far below the total average for the tunnel (pl. 1, stas. $164+00$ to $305+50$ ).

A section of the tunnel in erratically sheared mylonite is depicted on plate $8 B$ (stas. $200+00$ to $201+50$ ). The mylonite resembles a quartzite, but it is a finely pulverized aplitic rock which is partly to completely cemented by quartz. Closely spaced intersecting shears are filled with gouge; and the rock exerted very heavy loads, which required 6-inch supports on 0.5 - to 1.0-foot spacing between stations $200+00$ and $202+20$. Figure $20 \mathrm{~A}$ is a photograph which shows the closely spaced, strutted steel supports in this section of the tunnel. Ground water was encountered in sufficient amounts beyond station $204+20$ to require grouting. Faults in the water-bearing section did not contain as much gouge as in the section between stations $190+00$ and $204+20$ and the free movement of water in the rocks is attributed to the more open nature of the fractures. The mylonite between stations $206+40$ and $207+50$ is a fairly competent, unfractured rock and required supports only on 4 -foot centers. Plate $8 B$ shows a close correlation between the rate of progress at the tunnel heading and the geologic structure.

Plate $8 C$ indicates the nature of a tunnel section that contains gently dipping faults and considerable ground water in quartzose mylonite (stas. $215+00$ to $222+50$ ). Heavy loading by closely sheared, altered gougy rocks in and adjacent to a very strong flat fault near station $216+40$ reduced progress and required installation of 8 -inch steel sets with struts. Gouge from the fault was analyzed; it consists of a finely crushed aggregate containing abundant quartz and smaller amounts of microcline, plagioclase, kaolinite, montmorillonite, and sericite. Montmorillonite in the gouge promoted swelling and created additional loads on the supports. Loads created by crushed water-bearing rocks beneath a flat fault, shown in section east of station $218+00$, required steel sets on 2.5-foot centers. The shattered rocks below the fault contained only small amounts of gouge and clay minerals and took large amounts of grout. Progress in the section beneath the fault was slowed by the interruptions necessitated by placement of support and by extensive grouting.

The gently dipping faults in the tunnel section 
between stations $215+00$ and $222+50$ (pl. $8 \mathrm{C}$ ) dip in the same general direction as the main shear zone of the Williams Range thrust fault in the vicinity of station $180+00$ and probably are subsidiary shear zones developed in the upper part of the thrust plate by the same mechanism that operated to produce the larger structure. It is noteworthy that the gently dipping faults contain brecciated fragments of mylonite, which itself is a thoroughly crushed, recemented material.

The part of the tunnel illustrated on plate $8 D$, in well-cemented mylonite between stations $240+00$ and $247+50$, required only light support for most of the interval. Intersecting faults and associated crushed, gougy rocks near stations $242+00$ and $247+00$ produced heavy ground. Brittle mylonite in intervening sections contained fewer faults than in most other parts of the tunnel in the thrust plate, but the faults contained large amounts of ground water under pressure. The average rate of progress generally was satisfactory.

One of the strongest faults in the Roberts Tunnel was intersected near station $273+00$ (pl. 9A). The fault contained 5-6 feet of wet gouge; biotite gneisses above the fault and in the hanging wall were closely sheared. The fault marks the eastern limit of the mylonitic rocks in the Roberts Tunnel. East of the fault, biotite gneiss is exposed in the tunnel as far as the Williams Range thrust fault at station $291+60$. Samples of altered gouge collected at stations $273+00$ and $275+84$ contain abundant kaolinite and montmorillonite, which were formed by alteration of crushed plagioclase in the gneiss. Loads on the supports resulted from the extreme incompetence of the clayey, crushed gneisses and from the tendency of the montmorillonitic rocks to swell when in contact with water. Heavy pressures on closely spaced 8-inch strutted steel supports caused several sets to be dislocated or deformed (fig. 20B). Advance of the heading was accomplished only by extensive use of spiling, driving of top headings ahead of the main bore (fig. 20C), and extensive use of breast boards and timber lagging at the tunnel heading (fig. $20 D$ ).

Swelling of the gouge and squeezing through narrow openings in almost solid timber lagging continued for many months and required constant cleanup of the tunnel until the concrete lining was placed. Efforts to prevent flow of mud into the tunnel were not completely successful, and it was concluded that it was better to allow controlled flow of the mud than to cause additional deformation or failure of the steel sets by completely containing the swelling rock.

Ground water in amounts sufficient to require grouting was encountered only in the fractured biotite gneisses above the fault where gouge in the fractures and argillic alteration in the wallrocks were not conspicuous.

Plate $9 B$ shows biotite gneiss brought into contact with hornfels by displacement along the Williams Range thrust fault near station $291+60$. Close shearing associated with faults is more localized than in the tunnel section east of the Williams Range thrust fault, where it was first encountered at station $180+00$, and two intervals between stations $285+00$ and $292+50$ required steel supports on only 5 -foot centers. A 4-foot-thick gouge zone in a fault at station $287+25$ contains abundant montmorillonite, kaolinite, and crushed quartz and produced heavy squeezing ground that made necessary installation of struts in the 8-inch steel sets to prevent their dislocation and deformation. Another section of very heavy ground was encountered in broken and altered rocks above and below the Williams Range thrust fault. Ground-water flows into the tunnel were most pronounced in the relatively unfractured gneisses between faults.

\section{CONCRETE LINING}

Concrete used in lining the tunnel between stations $180+00$ and $291+60$ was of two classes. Class "AA" concrete, which contained Type I cement, was designed to have a 28-day strength of $4,500 \mathrm{psi}$ and was placed in parts of the tunnel that required very strong support. Class "AA" concrete was used in seven sections between stations $180+00$ and $291+60$ for an aggregate length of 67 percent of the total interval. For the remainder of the interval, class " $A$ " concrete was placed. This concrete was designed to provide a minimum strength of $3,000 \mathrm{psi}$ in at least 90 percent of the tested samples. 

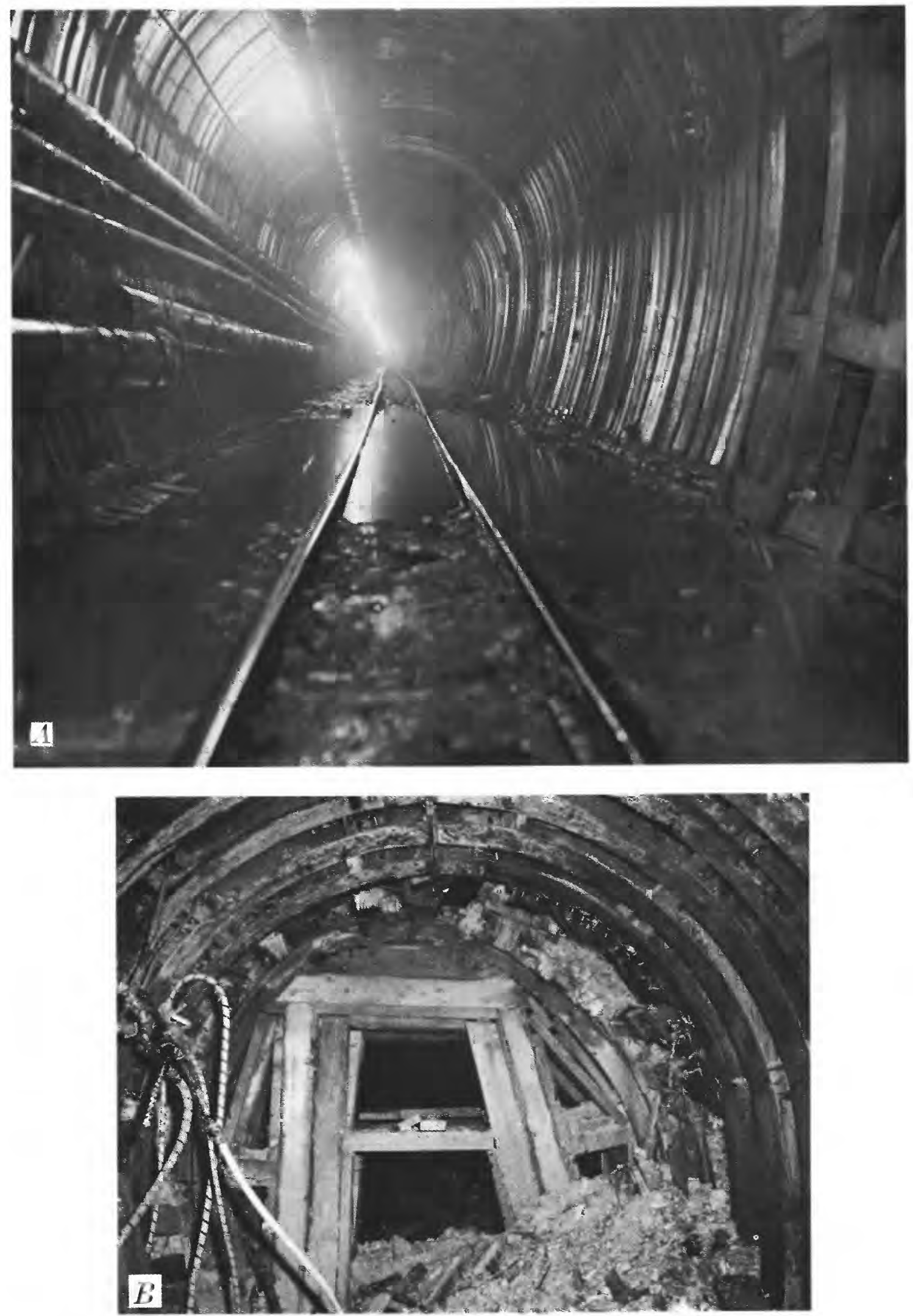

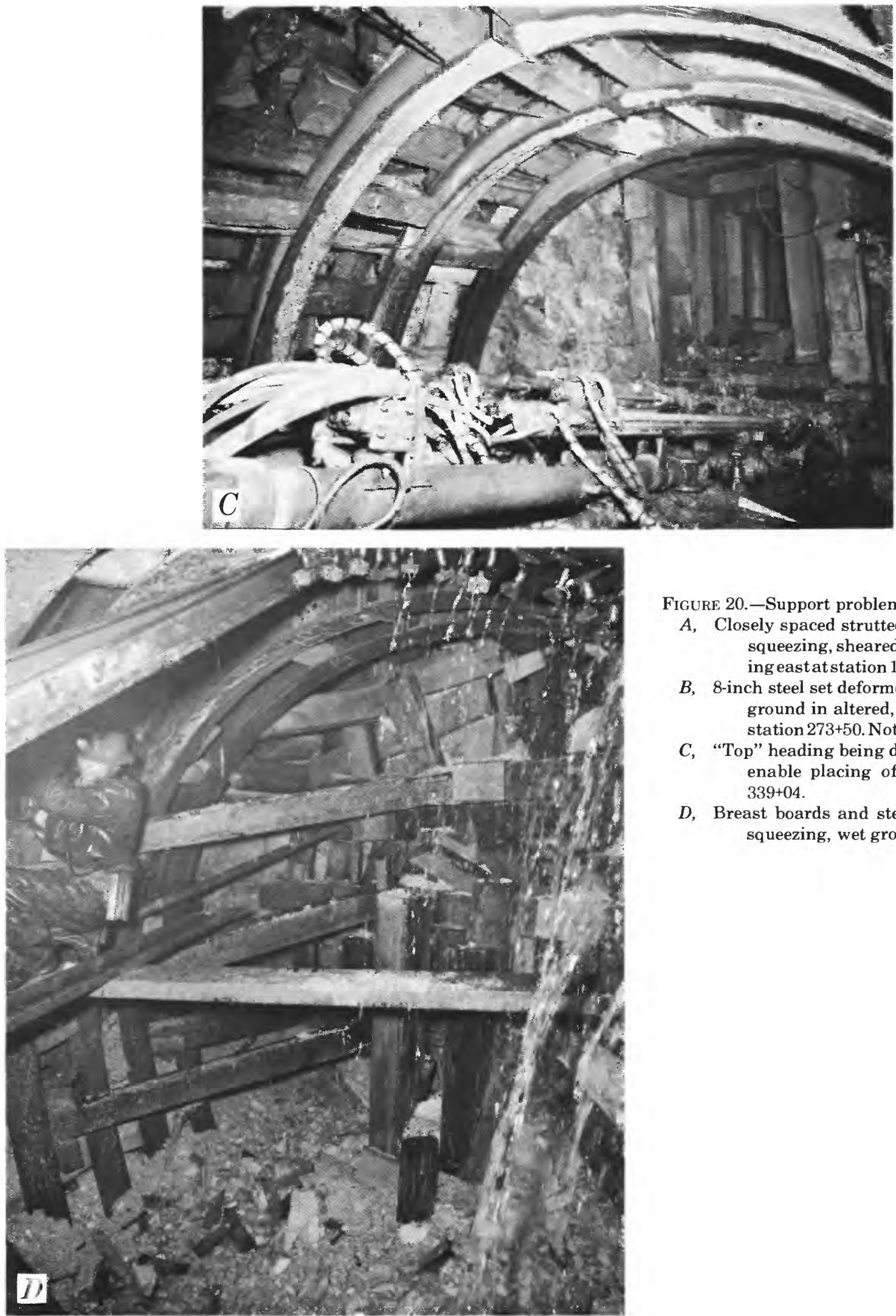

Figure 20.-Support problems in the Roberts Tunnel.

$A$, Closely spaced strutted 6 -inch steel supports in squeezing, sheared and altered gneiss. Looking east at station $199+50$.

$B, \quad 8$-inch steel set deformed by squeezing, swelling ground in altered, sheared biotite gneiss at station $273+50$. Note steel rail spiling in arch.

$C$, "Top" heading being driven in heavy ground to enable placing of steel supports, station $339+04$.

$D$, Breast boards and steel rail spiling in heavy, squeezing, wet ground at station $274+65$. 


\section{Stations $291+60$ to $343+00$ Metamorphosed Mesozoic Sedimentary Rocks}

\section{GEOLOGY}

The rocks between stations $291+60$ and $343+00$ in the Roberts Tunnel (pls. 1,9) are black to gray, highly fractured, very brittle metamorphosed shales, sandy shales, shaly siltstones and sandstones, limy shales, and limestones. The rocks are below and east of the Williams Range thrust fault and west of the Montezuma stock, which intruded them and metamorphosed them, in part, into hornfels. Identification of the stratigraphic positions of the original sedimentary layers is based on correlation of a 100-foot-thick siltstone and sandstone layer near station $318+00$ with a siltstone and sandstone layer of similar thickness and lithology in the Pierre Shale near station $110+00$ and on correlation of a lime-silicate layer just east of a strong fault at station $339+30$ with the Fort Hays Limestone Member of the Niobrara Formation near station $57+00$. If the sandstone correlation is correct, the thickness of the Pierre Shale section below and east of the Williams Range thrust fault at station $291+60$ is about 1,900 feet as compared with a thickness of about 2,500 feet below and west of the fault at station $180+00$. Thus, in the interval between stations $180+00$ and $291+60$, the fault surface has cut across a thickness of 600 feet of sedimentary rocks in the Pierre Shale. On the assumption that the correlation of the lime-silicate rock with the Fort Hays Limestone Member of the Niobrara is correct, rocks, east of the lime-silicate layer and extending as far as the west contact of the Montezuma stock at station $343+00$, are the metamorphosed counterparts of black carbonaceous shales of the Benton Shale exposed in the tunnel west of station $56+50$.

\section{PETROGRAPHY}

Mineral associations and rock fabrics indicate a gradual increase in intensity of metamorphism in the direction of the Montezuma stock. Rocks just east of the Williams Range thrust fault are dominantly baked brittle shales and sandy shales that have mineral assemblages and fabrics generally similar to those of their unmetamorphosed counterparts west of station $180+00$. As the stock is approached in the tunnel, contact metamorphic effects become more noticeable by a gradual but erratic increase in grain size by recrystallization of originaly very fine grained components, by the disappearance of certain minerals, and by the appearance of others. The baked shales and sandy shales have densities of 2.70-2.75-a result of compaction, dehydration, and partial recrystallization-as compared with densities of 2.60-2.65 for shaly rocks west of station $180+00$ and of 1.6-2.3 for Pierre Shale from other localities (H. A. Tourtelot, written commun., 1962). Bedding is generally well preserved even in the most intensely metamorphosed rocks, but a conspicuous crosscutting cleavage resulting from closely spaced microshears that developed prior to metamorphism is present in many exposures.

Sandstones and siltstones of the Pierre Shale have not been notably affected by metamorphism, except for recrystallization and grain enlargement of the minerals in the originally fine grained matrix.

The most notable effects of metamorphism were in impure calcareous rocks 300 feet west of the stock, where recrystallization caused development of limesilicate rocks. However, calcareous layers anc calcitic shell fragments in otherwise noncalcareous shales 2,500 feet west of the stock have not reacted with associated silicate minerals to produce new minerals.

There is no indication of extensive introduction of materials into the shaly and limy rocks during metamorphism. Recrystallization appears to have been mainly isochemical, except for loss of water, and, in the lime-silicate rocks, loss of carbon dioxide. Hydrothermal solutions penetrated the rocks after metamorphism and produced narrow veins, which contain calcite, quartz, and sparse sulfides. Black metamorphosed shales adjacent to mineralized fractures locally contain abundant disseminated fine-grained pyrite. Narrow bleached zones in the walls of veins contain small amounts of pyrite, montmorillonite, sericite, and fine-grained quartz.

Noteworthy aspects of the rocks in the tunnel in the inteval between the Williams Range thrust fault at station $291+60$ and the contact of the Montezuma stock with the metamorphosed sedimentary rocks near station $343+00$ are given in the following summary.

Stations $291+60$ to $316+50$.- Rocks in this interval are fine-grained brittle slightly metamorphosed shales, siltstones, and sandy shales of the Pierre Shale. The shales, between stations $291+60$ and $305+00$, contain abundant quartz, illite ( $2 \mathrm{M}$ muscovite), and varying amounts of kaolinite and amorphous carbonaceous material. Clastic angular to subangular grains in the sand-size fragments in 
the sandy shales are dominantly quartz but a few are fresh potassium feldspar and plagioclase. A perceptible increase in the size of the illite plates, as the stock is approached in the tunnel, results from slight recrystallization of the illite in the nearly submicroscopic aggregates of the original rocks.

Kaolinite could not be identified in X-ray diffractographs of tunnel rocks closer than about 4,000 feet to the Montezuma stock. Its disappearance from the rocks is attributed to its destruction by heat from the stock.

Stations $316+50$ to $319+00$. - In this interval the tunnel passes through a 100-foot-thick layer of metamorphosed shaly siltstone and sandstone. Angular to subangular grains of quartz, of minor amounts of potassium feldspar, and of plagioclase are embedded in a partially recrystallized matrix containing abundant illite ( $2 \mathrm{M}$ muscovite). Outlines of individual illite plates are easily seen under the microscope. Sand-size grains average from 0.15 to $0.20 \mathrm{~mm}$ in diameter (fig. 21). No overgrowths were

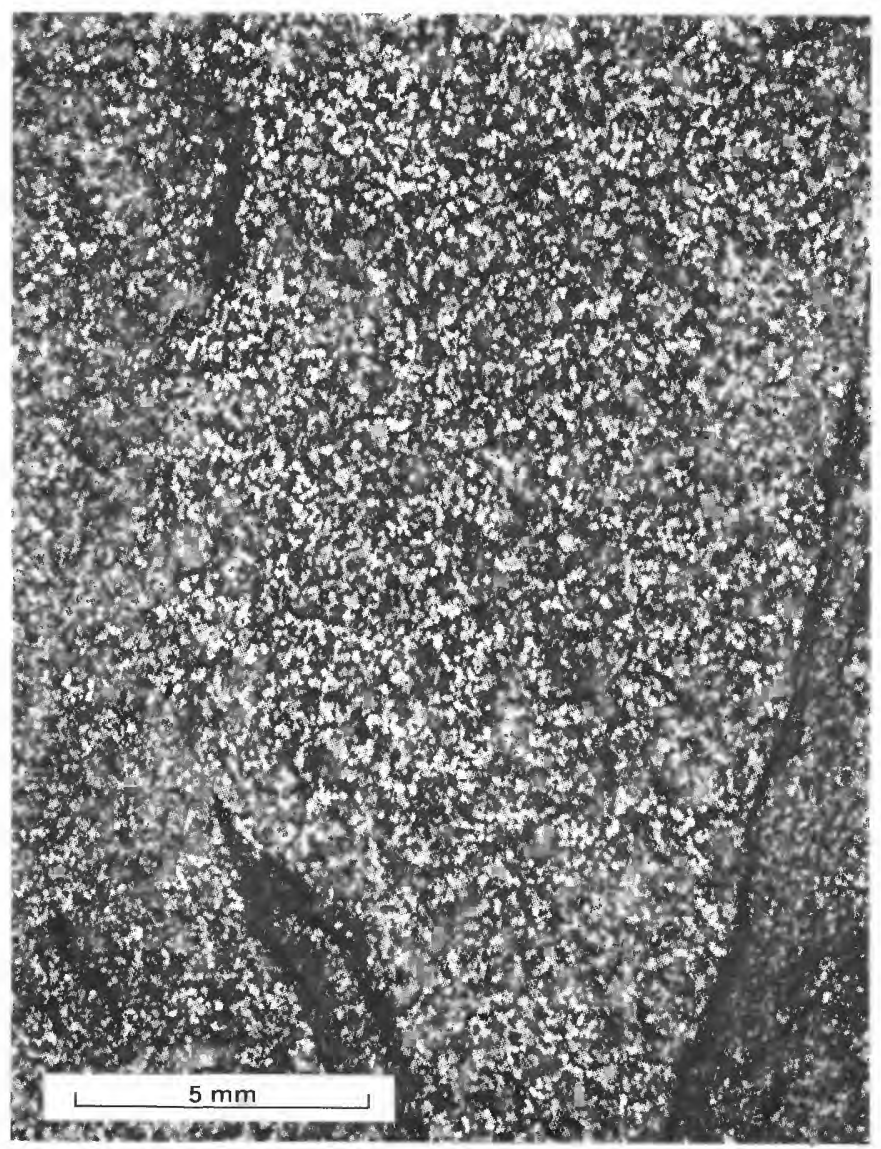

FIGURE 21.-Photomicrograph of metamorphosed sandstone in baked shale sequence. Diamond drill hole A, depth 578 feet. Crossed polars. observed on quartz grains, and, except for the larger size of illite plates in the matrix, the fabric of the sandstone is almost identical to that of unmetamorphosed siltstones and sandstones in the Pierre Shale (fig. 22) west of the Williams Range thrust fault.

Stations $319+00$ to $339+30$. - This part of the tunnel is in beds of metamorphosed shale and sandy shale of the lower part of the Pierre Shale. The shales terminate abruptly against a strong fault at station $339+30$ (pls. 1, 9E) and abut lime-silicate rocks that were probably derived from the Fort Hays Limestone Member of the Niobrara Formation. In tunnel exposures, the baked shales are fine grained and gray to black, and their bedding is conspicuous. In thin section a fine-grained hornfelsic fabric is observed in some layers and, although the individual mineral grains are very small, it is evident that most of the original components have recrystallized. Quartz, illite, and minor amounts of potassium feldspar are characteristic minerals and, in originally

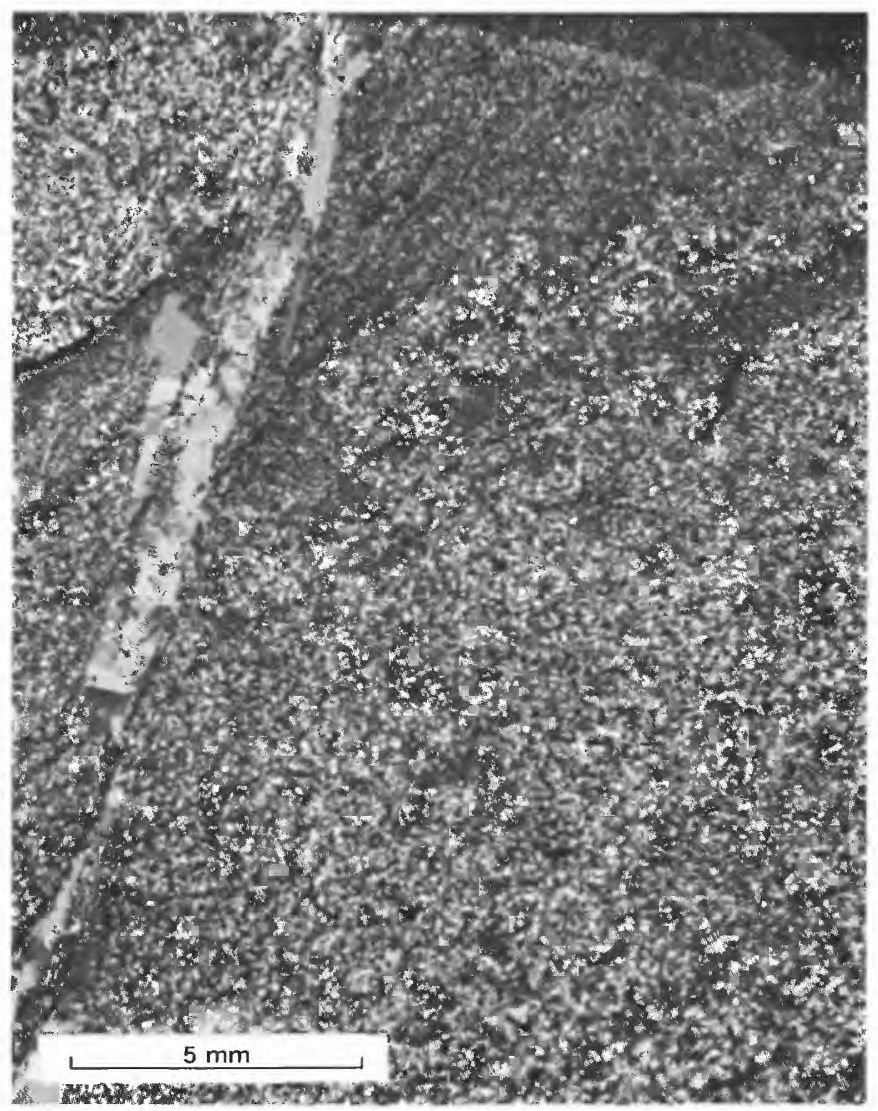

FIGURE 22.-Photomicrograph of unmetamorphosed sandstone from Pierre Shale. Station $114+50$. Vein contains calcite. Crossed polars. 
carbonaceous rocks, a noncrystalline graphic material forms powdery disseminations in and around the other mineral grains.

Cordierite appears in metamorphosed shaly rocks about 2,000 feet west of the stock. The cordierite has formed only in layers originally rich in clay minerals and does not appear in sandy layers (fig. 23). The crystals increase in size and contain progressively fewer inclusions with increasing proximity to the Montezuma stock (figs. 25, 26).

Extensive shearing of the fine-grained shales prior to metamorphism is evident in some thin sections, shearing probably resulted from movements accompanying the development of the Williams Range thrust fault. Figure 24 shows a highly sheared, partly recrystallized carbonaceous shale. Very fine grained black illitic material is the matrix for lenticular noncarbonaceous segregations of illite plates and angular sand grains. The planar fabric, which has resulted from shearing, intersects beddirig; moreover, in rock exposures in the tunnel

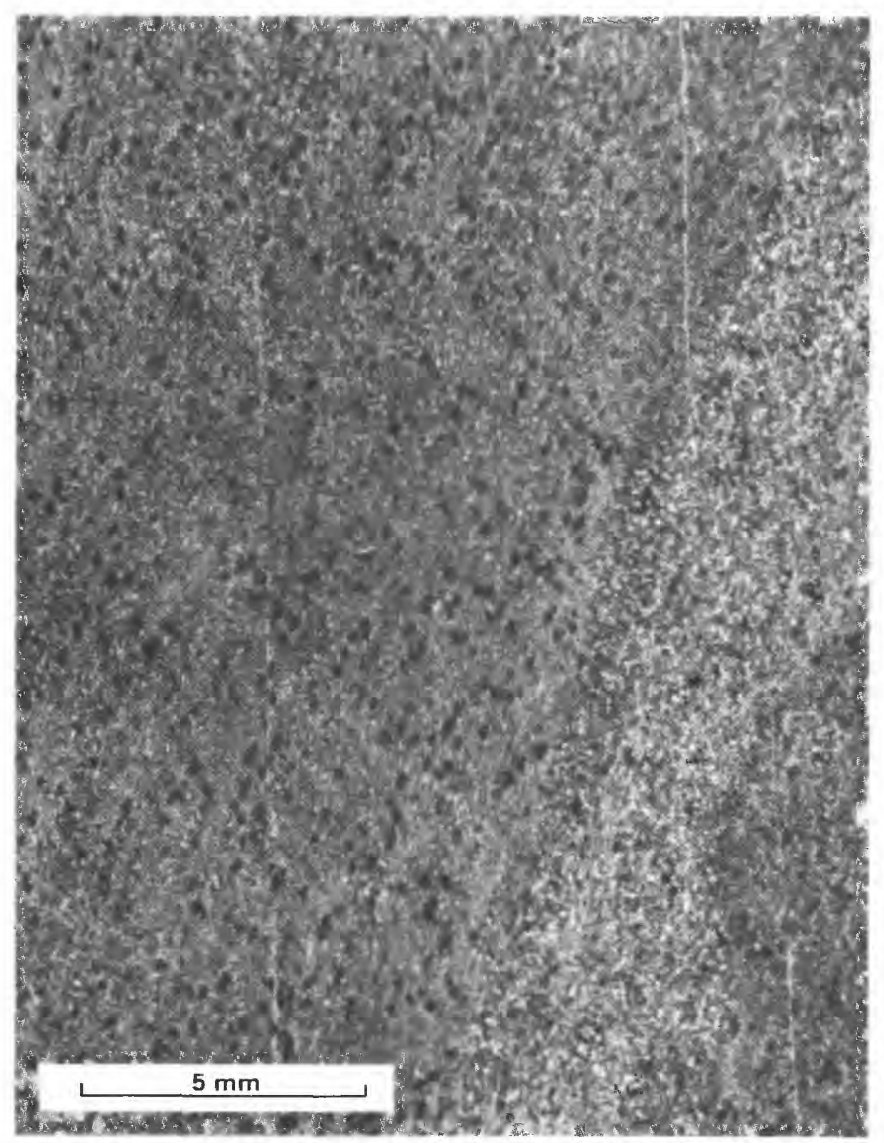

FIGURE 23.-Photomicrograph showing cordierite crystals (black) in fine-grained hornfels formed from sandy Pierre Shale. Station $324+00$. Crossed polars.

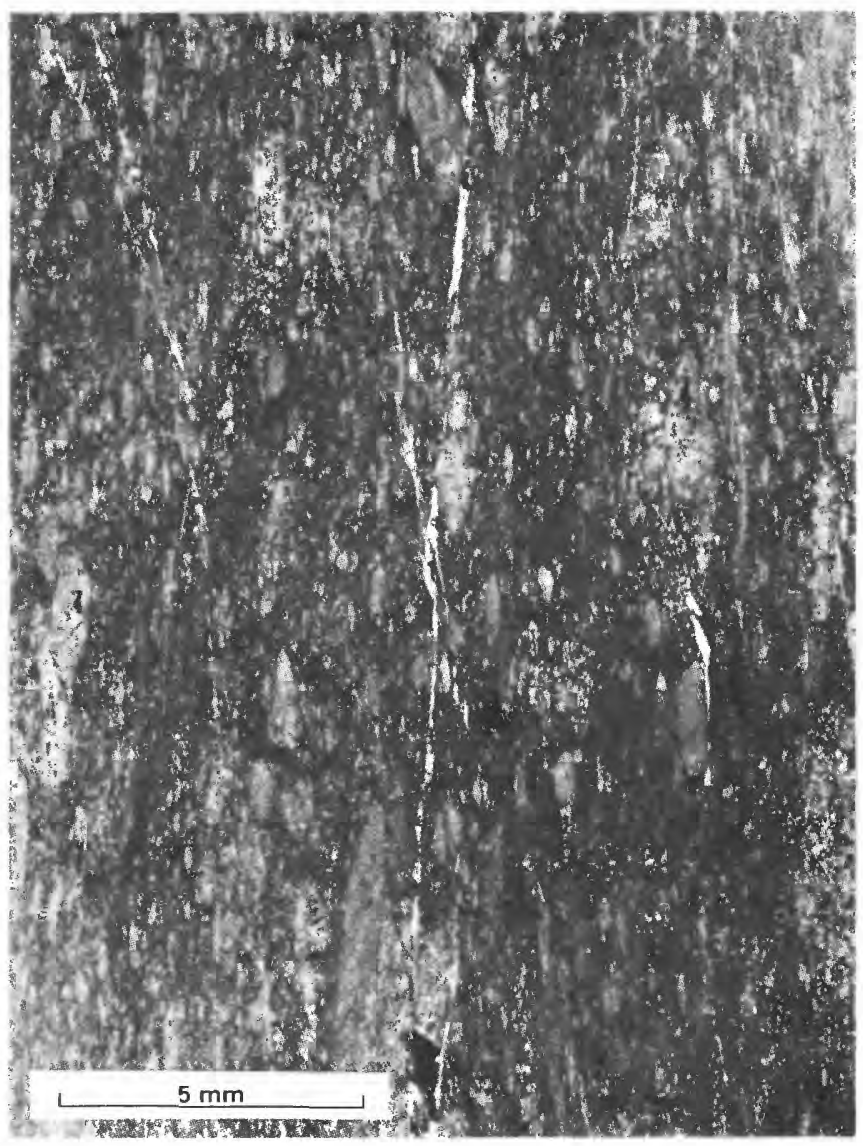

FIgURE 24.-Photomicrograph of sheared baked shale. Note augenlike segregations of sand-size particles of quartz. Station $334+00$. Plain light.

the planar fabric expresses itself in many places by conspicuous rock cleavage.

Station $339+30$ to $340+50$.- Light-gray to green lime-silicate rock in this interval probably formed by metamorphic recrystallization of the Fort Hays Limestone Member and (or) of the shaly limestones at the top of the Benton Shale. The fabric is erratic and ranges from microcrystalline to coarse-grained crystalloblastic.

Garnet crystals (grossularite) attain diameters of at least an inch and are embedded in a matrix of calcite, or pyroxene (probably diopside), or various proportions of both minerals. Tremolite as tiny needles is a minor constituent. In the metamorphosed shaly limestones, gradations exist between garnet-pyroxene-calcite rocks and rocks that contain quartz, feldspar, illite ( $2 \mathrm{M}$ muscovite), and graphite.

Stations $340+50$ to $343+00$, approximately.-The 


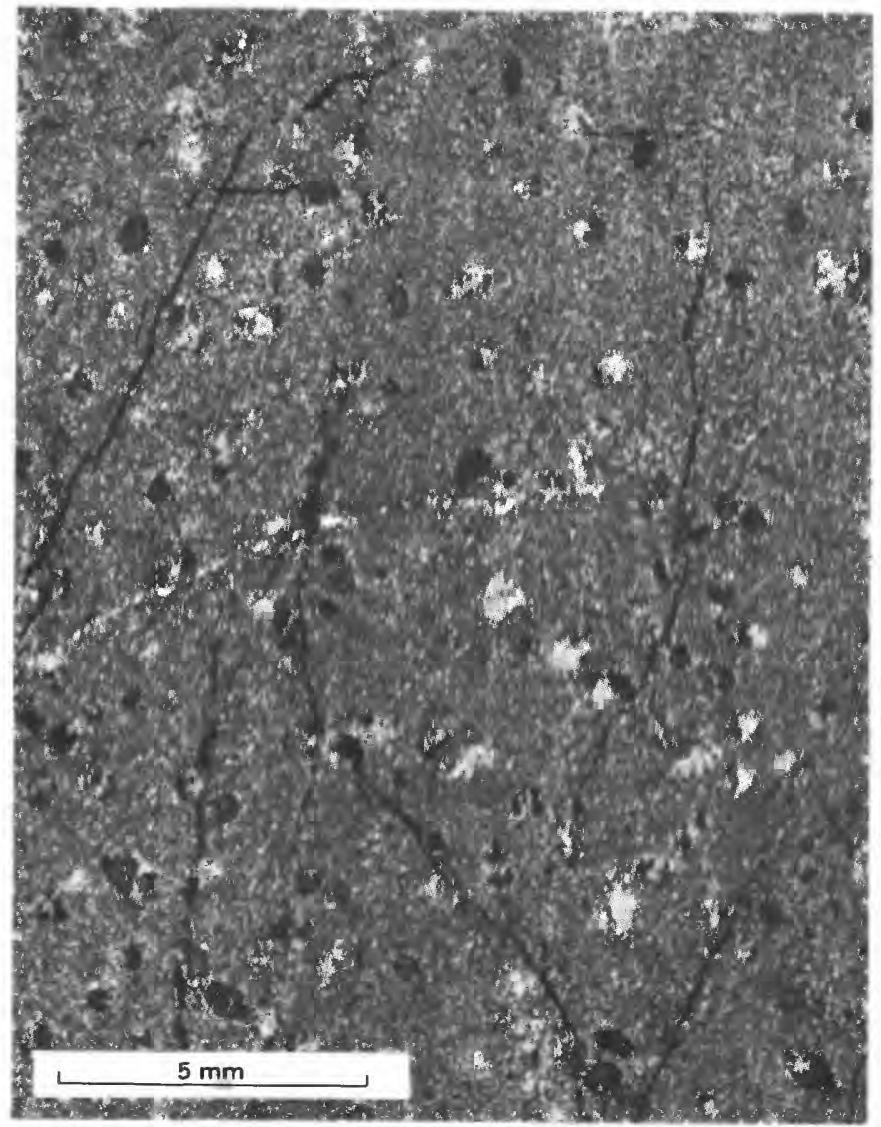

FIGURE 25.-Photomicrograph showing cordierite metacrysts in fine-grained hornfels formed by metamorphism of probable Benton Shale. Station 343+00. Crossed polars.

top of a section of metamorphosed highly carbonaceous shales, probably of the Benton Shale, is recognized by a 5-foot-thick quartzite layer at station $340+50$. Above the quartzite are probably the metamorphosed shaly limestones which constitute the top of the Benton Shale. Metamorphism of the shales below the quartzite resulted in fine-grained hornfels which contain quartz, illite (2M muscovite), biotite, orthoclase, twinned cordierite (fig. 25), and graphite. Muscovite is practically absent from rocks that contain orthoclase; this absence suggests a breakdown of the muscovite to contribute to the formation of the feldspar. Biotite forms separate scattered crystals or aggregates molded around and filling interstices among other minerals. Graphite, derived from abundant organic material, is present as numerous small scattered round grains that are sufficiently crystalline to yield low peaks in diffractometer tracings.

An inclusion of the shale in the stock at station

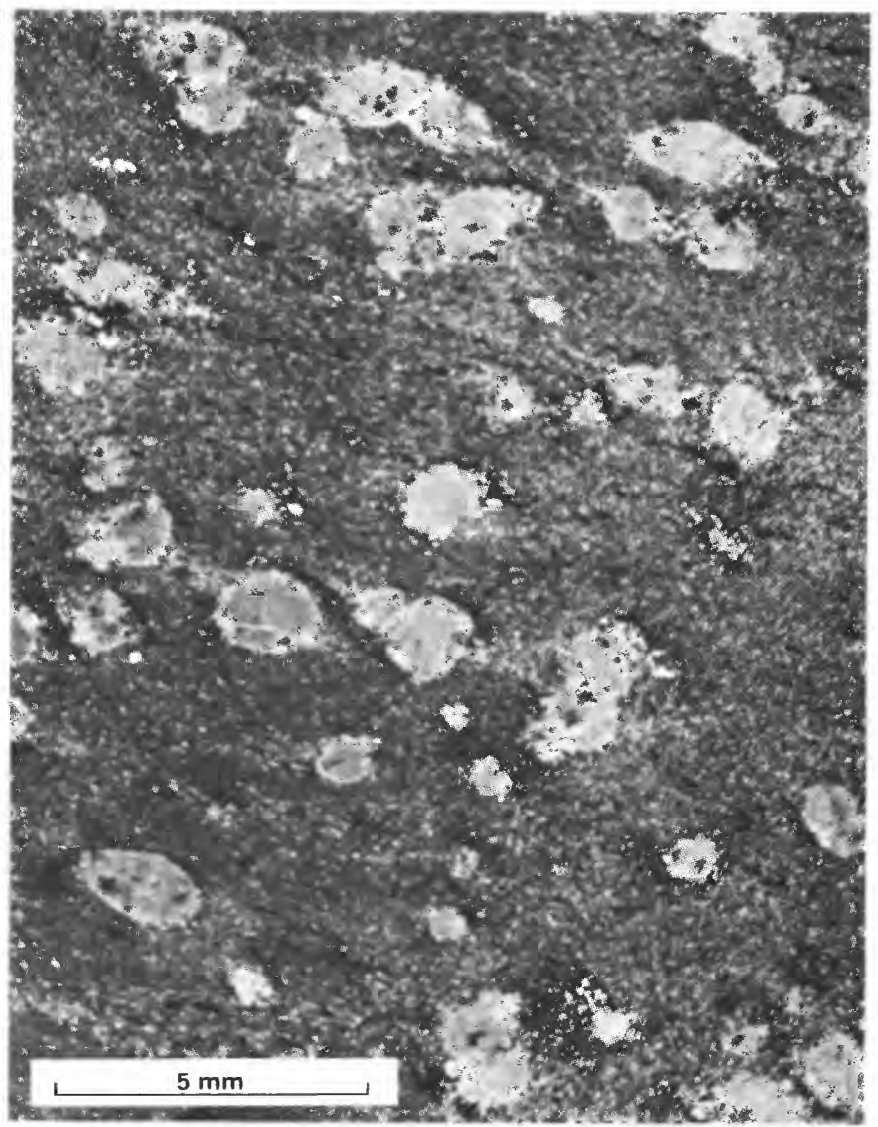

FIgURE 26.-Photomicrograph showing altered cordierite metacrysts in a hornfels inclusion in quartz monzonite. Station $347+43$. Crossed polars.

$347+43$ contains cordierite crystals that have been altered to fine-grained muscovite (fig. 26). Biotite in single crystals and aggregates are altered to chlorite. Muscovite and chlorite probably resulted from alteration caused by late hydrothermal solutions.

\section{STRUCTURE \\ FAULTS AND JOINTS}

The brittle baked shaly, sandy, and limy rocks are closely faulted and jointed. Plate 1 (stas. 291+60 to $343+00$ ) indicates by contoured equal-area plots the varying attitudes of the poles of planar elements. Many strong joints strike N. $55^{\circ} \mathrm{W}$. and dip steeply toward the north; whereas faults commonly strike N. $10^{\circ} \mathrm{E}$. and dip about $35^{\circ}$ to the west; this attitude of the faults is subparallel to the attitude of the Williams Range thrust fault in the tunnel at station $291+60$. Steep faults in the baked shale have strikes and dips parallel to the steep faults in Precambrian 
rocks west of the thrust fault and to the east in the Montezuma stock.

Most of the joints and the faults probably predate the intrusion of the Montezuma stock and probably were formed at the same time as the Williams Range thrust fault, but a few faults may have been caused or accentuated by the intrusion of the stock. Faults that dip gently to the west near station $335+00$ may be subsidiary shear zones that were formed in the shale at the same time that the Williams Range thrust fault developed, but they are 1,900 feet stratigraphically lower than the main thrust surface. A few faults contain crushed fragments of contact metamorphosed rocks that contain fractures filled with hydrothermal sulfide mineralization. This relationship indicates movements after the intrusion of the stock and before mineralizing solutions genetically related to the stock penetrated the surrounding rocks.

In the interval between stations $291+60$ and $343+00,189$ large and small faults were mapped; also, 312 strong joints were mapped, but this number does not adequately represent the highly fractured nature of the brittle rock that is intersected by the tunnel. Practically all exposures in the tunnel showed complexly intersecting more or less closely spaced joints (fig. $27 A$ ), especially in the vicinity of faults. The strong joints commonly form series of subparallel closely spaced partings in the rock that cause the rock to break into thin sheets or slabs, generally across the bedding. Thin sections of the sheeted rocks show a profusion of microshears parallel to the direction of splitting.

Plate 1, (stas. $291+60$ to $343+00$ ) includes equal-area plots that show statistical concentrations of faults, joints, and bedding planes. Figure 28 is a diagram that shows the average attitudes of planar features as indicated by concentrations in the equal-area plots.

\section{ENGINEERING PRACTICES IN RELATION TO GEOLOGY}

The engineering practices were directly controlled in this interval of the tunnel by the structure of the rock. The amount of overbreak, support requirements, the amount of ground water-and therefore the amount of grout required-were proportional to the intensity of the fracturing. Progress was, in general, inversely proportional to the time required for grouting operations.

\section{OVERBREAK}

Overbreak in the metamorphosed sedimentary rocks resulted from a combination of factors, but depended mainly on the presence of a multitude of intersecting fractures in highly brittle rock. Bedding, although observable in most exposures, played a minor part in determining the manner of breaking of the rock by explosives during the tunneling operation. Overbreak was especially large in and near faults that have intricate joint patterns or in fault zones that contain crushed gougy materials and water.

Plates $4 F, 4 G, 4 H$, and $4 I$ show overbreak as related to the geology in four representative intervals of the tunnel. The tunnel heading in all examples was driven from east to west; that is, in the direction of decreasing station numbers.

Plate $4 F$ illustrates overbreak in shattered baked shales just below and east of the Williams Range thrust fault. Fracturing is so closely spaced and so intricate that the rock is almost isotropic in its behavior. A slight arching tendency is attributed to the natural tendency of the fractured roof rock to fall away as the tunnel opening is driven. Slight asymmetry in the arch overbreak appears to be related to especially strong continuous fractures and, to a lesser extent, to splitting along bedding planes in the dipping baked shales.

Plate $4 G$ illustrates overbreak in a section of strong subparallel steeply dipping joints intersecting brittle baked shale. An elliptical average cross section resulted from the breaking of the rocks to the joints; here, the influence of the joints far outweighs the influence of the bedding in determining the manner in which the rock broke by blasting. Overbreak asymmetry is strongly indicated, not only in the average cross section, but also in the section with maximum overbreak-at station $300+70$.

On plate $4 H$, overbreak is related to geology in this section of the tunnel through the presence of mildly faulted and jointed baked shaly sandstone. Bedding in the sandstone is emphasized by thin shaly partings; in the tunnel heading it appears to be nearly horizontal. Overbreak in the arch was at a

FIGURE 27 (facing page).-Baked shalein Roberts Tunnel.

$A$, Heading at station $341+64$ in highly jointed baked shale.

$B$, Water under high pressure issuing from exploratory diamond drill holes penetrating fault zone in baked shale. Heading at station $339+50$. 
GEOLOGY, WESTERN PART, (STATIONS 0+00 TO 690+00)
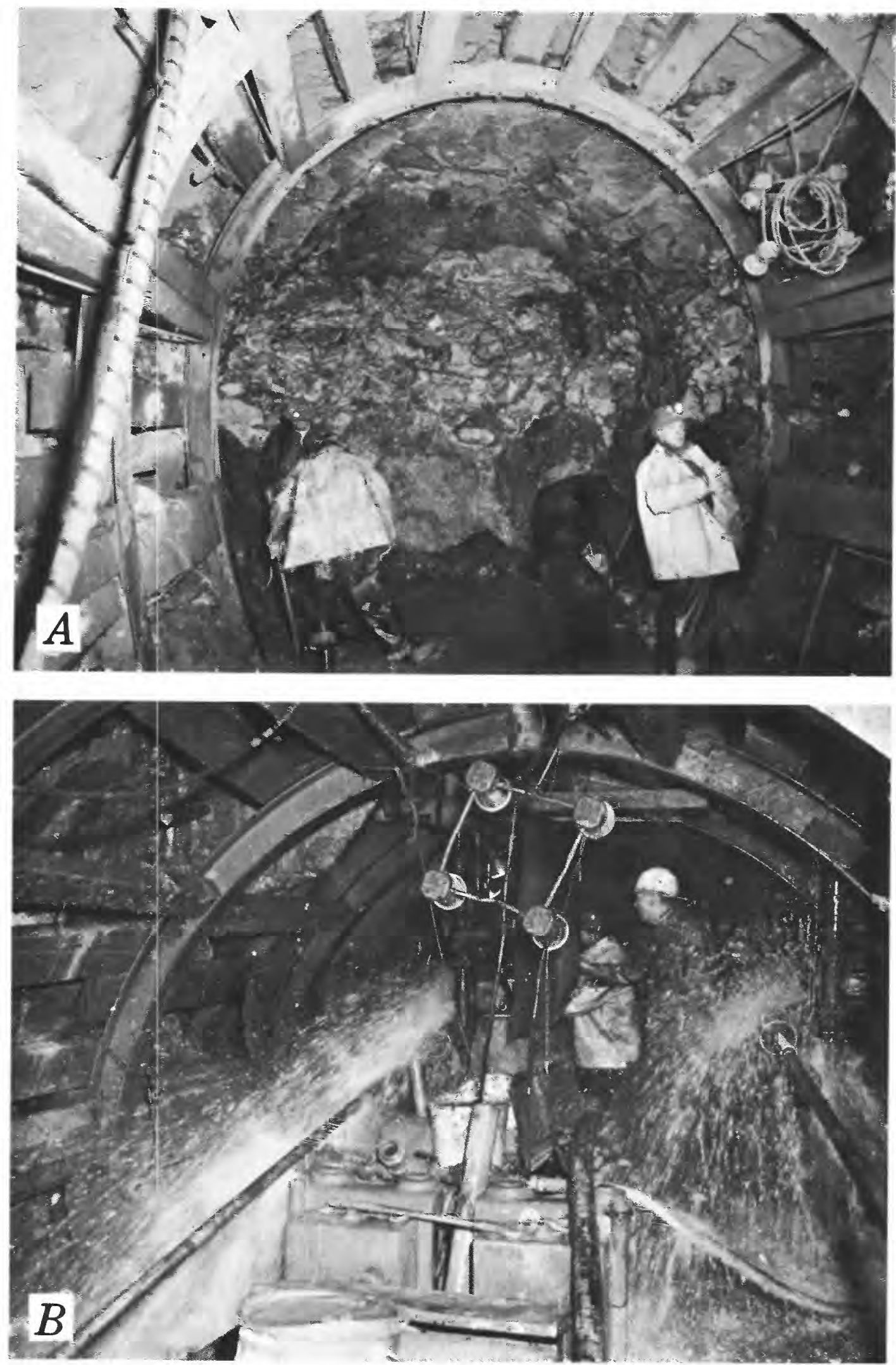


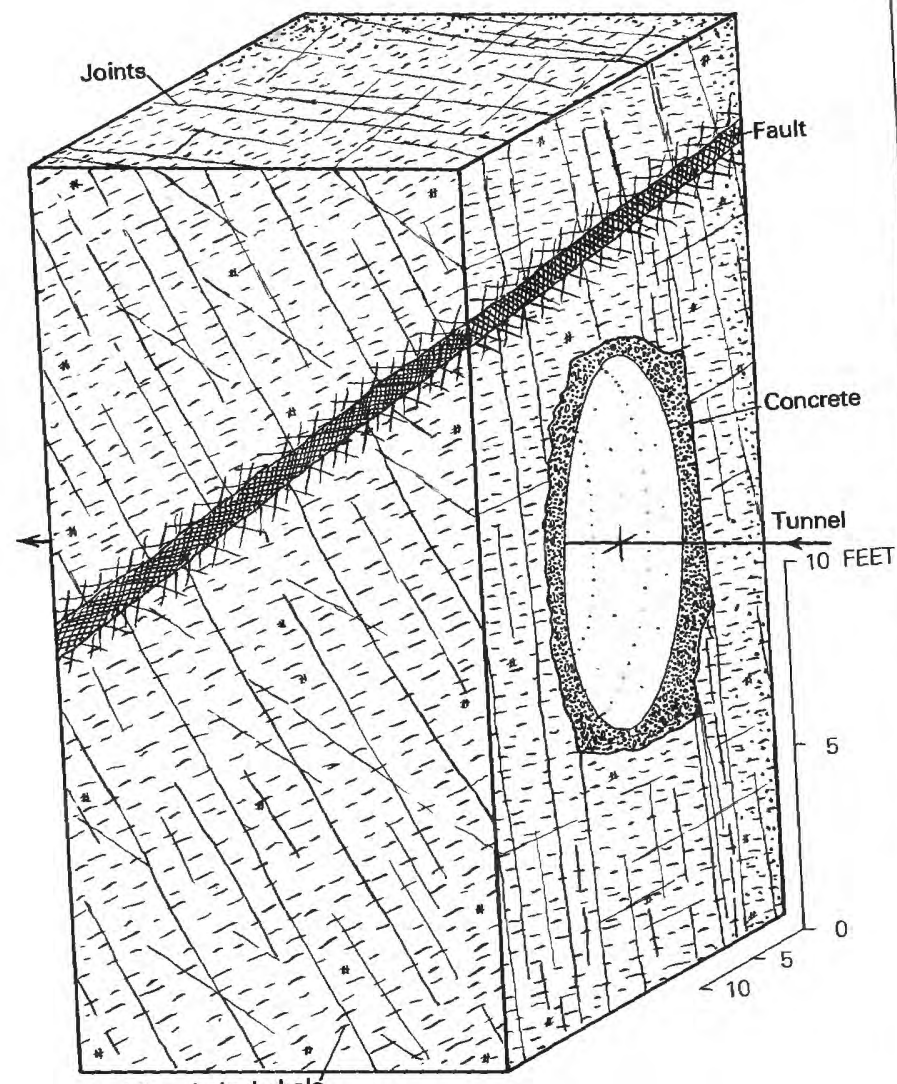

Bedding, baked shale

28. Dhowing average attitudes of planar Roberts Tunnel between stations $291+60$ and features in the Roberts Tunnelion of tunnel heading $343+00$. Arrow

(S. $75^{\circ} 59^{\prime}$ E.)

minimum in the center of the tunnel, but it flared outward at the sides of the arch where intersection of bedding planes with steeply dipping fractures produced blocky rock that broke easily outside of the payline.

Plate $4 I$ illustrates an interval of relatively unfractured baked shales excavated with an average overbreak of only 10.1 percent, which is a generally low value for an interval that requires support. The outline of the average section conforms closely to the outlines of the blasthole pattern (fig. 12) and the payline. Minimum overbreak in the center of the arch indicates a slight tendency for the rocks to break cleanly to bedding planes.

\section{SUPPORTS, AND PROGRESS}

Plate 1 (stas. $291+60$ to $343+00$ ) shows graphically the extent of feeler-hole operations, the amount of ground water intersected in feeler holes, the types of grouting operations, the use of steel supports, and the rate of advance of the tunnel heading as related to geological conditions. Plates $9 B, 9 C, 9 D$, and $9 E$ illustrate the same features in selected intervals of the tunnel and at a larger scale than on plate 1 .

Feeler holes were drilled from the heading for the entire interval in the metamorphosed sedimentary rocks between stations $291+60$ and $343+00$ (pls. 1,9). Heavy ground-water flows occurred in the sandstone ayer between stations $316+50$ and $319+00$ and within and in the vicinity of strong faults; they required large amounts of grout to seal them. Several sections of the tunnel contained numerous tight joints from which small amounts of water dripped but no effort was made to stop the dripping by grouting.

Steel supports on 2.5- and 5.0-foot centers, some with struts, were installed for 97.7 percent of the interval between stations $291+60$ and $343+00$. Short intervals in rocks just west of the Montezuma stock, which consist of relatively competent, unfractured hornfels, did not require support. Elsewhere, pervasive jointing or heavy, water-bearing rocks in and near faults required that steel and timber supports be used to prevent collapse of the rocks into the tunnel.

Advance of the tunnel heading generally proceeded at a satisfactory rate. The poor progress in some intervals resulted from the necessity to stop tunneling operations while grouting was done to stop heavy waterflows that had been intercepted in feeler holes beyond the headings, particularly at station $339+50$.

Plate $9 C$ summarizes operations as related to geology and ground-water conditions in an interval of metamorphosed shales east of the Williams Range thrust fault-station $297+50$ and $299+50$ are in a zone of highly fractured water-bearing rocks below the thrust fault, and this interval required grouting and closely spaced supports. Beyond station $299+50$, the rocks are relatively free of fractures and required only light support on 5-foot centers to prevent rockfalls of jointed rock from the arch.

Plate $9 E$ illustrates a section of the Roberts Tunnel where very difficult conditions were encountered. Two wide, intensely fractured zones in brittle rocks wo heavy support. At station $339+50$ feeler in there drilled into the heading being driven westward from the access shaft encountered very heavy flows of water (fig. $27 B$ ). First attempts to seal off the waterflows with grout were unsuccessful. Additional feeler holes, including four long diamonddrill holes, were drilled beyond the heading; it then became apparent that water saturating a fracture 
zone nearly 90 feet wide was coming from the Snake River, which flows in a gravel-filled channel 550 feet above this part of the tunnel. A total of 38 short and long feeler holes were drilled from the heading and 23,435 sacks of cement were used in grouting operations before the tunnel heading could be advanced. Additional waterflows were encountered as the tunnel penetrated the fractured zone, but these flows were stopped by using only small additional amounts of grout.

\section{Stations $343+00$ to $690+00$ Montezuma Quartz Monzonite Stock}

Preliminary engineering studies were based on the assumption that a tunnel from Dillon, Colo., to the North Fork of the South Platte River would follow a straight line. (See 831-A, fig. 2.) Geologic studies indicated that all of the several proposed straightline routes would pass through long intervals of complexly fractured and altered rocks and, after considerable deliberation, the dogleg course that would pass through the Montezuma stock was adopted. Surface exposures of the stock suggested that the rock of the stock was less fractured and more competent than the Precambrian igneous and metamorphic rocks adjacent to the stock, and, therefore, required support was anticipated to be minimal where the tunnel penetrated the stock. The actual experience in the stock did not fulfill expectations. Argillic alteration, noted in cores from a diamond-drill hole at the site of the access shaft, proved to be widespread, and fracturing in the stock was much more extensive than was indicated by surface mapping. Much of the tunnel in the stock was driven in jointed, slightly altered rock that was on the borderline of competency and, in the interest of safety, installation of light steel and timber supports was required. Parts of the tunnel penetrated intensely argillized, squeezing rocks, which required theinstallation of additional supports several months after the rocks were exposed to moist tunnel air.

The part of the Roberts Tunnel in the Montezuma stock between stations $343+00$ and $468+49$, a distance of 2.37 miles, trends S. $75^{\circ} 59^{\prime} \mathrm{E}$. (pl. 1). At station $468+49$, the tunnel changes its leading to $\mathrm{S} .49^{\circ} 33^{\prime} \mathrm{E}$., a heading that is maintained to the East Portal, at station $1238+58$. Southeast of station $468+49$, the tunnel is in the Montezuma stock or in roof pendants of Precambrian rocks in the stock as far as station $689+00$, a distance of 4.17 miles (pls. 1, 10, 11).

At the surface above the tunnel the contact of the stock with Precambrian rocks is near station 577+00 and is about 2,200 feet above tunnel level (pl. 1). At tunnel level, a contact with Precambrian rocks was intersected near station $625+00,4,800$ feet beyond the contact at the surface. The tunnel heading was advanced 1,185 feet through foliated metamorphic rocks to station $636+85$, where quartz monzonite was again intersected; then, the tunnel continued to penetrate quartz monzonite to as far as station $686+50$.

\section{GEOLOGY}

The Roberts tunnel between stations $343+00$ and $690+00$ is chiefly in the Tertiary Montezuma Monzonite of the Montezuma stock (pl. 1). Precambrian rocks, consisting of varieties of biotite gneiss and pegmatite, were exposed in the tunnel and arebelieved to be a roof pendant in the stock. The stock is cut by faults, fault zones, and joints that are locally mineralized and form veins. At the time of formation of the veins, the wallrock of the veins was altered.

\section{ROCK UNITS \\ PRECAMBRIAN ROCKS}

The Precambrian rocks within the Montezuma stock are dominantly gneiss and pegmatite at tunnel level; they are exposed in the roof pendant between stations $625+00$ and $636+85$ and are exposed as three lenticular inclusions between stations $679+50$ and $684+50$. The foliation in the gneiss in the roof pendant is nearly at $90^{\circ}$ to the tunnel, has an average strike of about $\mathrm{N} .25^{\circ} \mathrm{E}$., and dips at angles generally greater than $80^{\circ}$. Inclusions near the southeast contact of the stock form lenses in which the foliation strikes about $\mathrm{N} .15^{\circ} \mathrm{E}$. and dips $50^{\circ}-60^{\circ} \mathrm{NW}$. Surface exposures, 4,000 feet above tunnel level, indicate that the structure in the layered rocks in the roof pendant is synclinal (pl. 1), but proof of a syncline in the rocks was not established by examination of the rock exposures in the tunnel.

The Precambrian rocks within the roof pendant and the inclusions of Precambrian rocks in the 
Montezuma stock are a medium- to coarse-grained quartzo-feldspathic gneiss, which contains several biotite-rich layers and several virtually conformable bodies of pegmatite and surgary aplite. The gneiss is hard and brittle, and on broken surfaces it has a glassy appearance resembling that of quartzite. Much of the gneiss is only slightly fractured or altered and was competent enough to stand without support during the advance of the tunnel heading.

Samples from several layers of the gneiss and from the pegmatites were examined under the microscope. Biotite gneiss, biotite-sillimanite gneiss, and gneissic biotite-bearing quartzite are the dominant types examined. The proportions of minerals differ from layer to layer, but quartz, orthoclase, and twinned oligoclase are present in all samples. Biotite, partly altered to chlorite, forms plates in subparallel orientation. Sillimanite, partly altered to sericite, appears as clusters of needles in some of the gneisses. Sericite has developed in plagioclase and is present as scattered tiny plates or, in some specimens, as aggregates that completely replace the plagioclase. Thin layers, rich in biotite and containing minor hornblende, are subordinate to the other gneissic rocks.

The pegmatites and aplites are dominantly quartz, orthoclase, and plagioclase. Sericite selectively replaces the plagioclase.

\section{MONTEZUMA QUARTZ MONZONITE}

The Montezuma Quartz Monzonite and associated intrusive rocks have been mapped and described by Lovering (1935). The Montezuma stock is one of a succession of Tertiary intrusive igneous bodies extending northeasterly across Colorado from the San Juan Mountains to Boulder County. The quartz monzonite and quartz monzonite porphyry in the stock have almost exactly the same fabric and mineralogy as the dominant rocks in the Mount Princeton Quartz Monzonite, a batholith in the Sawatch Range, 60 miles to the southwest, which was described by Crawford (1924).

The interior of the Montezuma stock is remarkably free of inclusions. A few angular inclusions of hornfels are present between stations $343+00$ and $347+00$ at tunnel level, near the west boundary of the stock, and three inclusions of Precambrian gneiss were intersected in the interval between stations $679+50$ and $684+50$, near the southeast limit of the stock. Visible flow layering and lineation are practically absent, and the fabric of the rock is virtually isotropic. Near station $356+00$, a few indistinct schlieren of dark minerals dip $10^{\circ}-20^{\circ} \mathrm{W}$.
Altered plagioclase feldspars in the interior of the stock locally show a poorly developed subparallel orientation and indicate a flat, indistinct flow layering. Lenses of gneiss near the southeast contact of the stock dip $50^{\circ}-60^{\circ} \mathrm{NW}$. and may be parallel to the contact of the stock with older rocks.

The contacts of the stock with older rocks are sharp, both on the surface and underground. Numerous satellitic dikes intersect the surrounding rocks. In the baked shales, irregular fine-grained tabular bodies of quartz monzonite have produced structural complexities in the shale by forcible plastic deformation. In the Precambrian rocks, crosscutting fine-grained dikes of quartz monzonite have followed sharply defined fractures. Aplite bodies, which are associated with the quartz monzonite stock, are especially conspicuous in the southeast contact zone of the stock and appear to have developed by crystallization involving reaction of the magma with older rocks. Aplites formed by fracture filling in the interior of the stock and formed slightly later than the aplite bodies, but in the southeast contact zone, adjacent to the contact with Precambrian rocks, some of the aplite is intruded by quartz monzonite and appears to be an older border phase.

The quartz monzonite probably was emplaced as a completely molten magma and probably crystallized almost entirely after emplacement. Indications of forceful emplacement of at least the upper part of the stock are numerous. In addition to deformation of the shale near the west contact, fault blocks above the stock have been differentially uplifted. Along the west side of the stock, forceful injection is indicated by upwarping and uneven uplift of the Williams Range thrust fault along several faults that intersect it. Dislocations of faults forced upward by the magma are from hundreds to thousands of feet. Some idea of the total amount of dislocation is suggested by the fact that at station $291+60$ in the tunnel, at an elevation of about 8,000 feet, the Williams Range thrust fault strikes northeast and dips $30^{\circ}-40^{\circ} \mathrm{NW}$., and on Independence Mountain, 2 miles southeast, the part of thrust fault that is exposed at the surface at an elevation of 11,500 feet, strikes eastward, and dips to the south. The southeast contact of the stock appears to be localized along a strong shear zone in Precambrian rocks (pl. 1 , near sta. $690+00$ ), and, there also, forcible uplift of the roof rocks of the stock is indicated.

The Montezuma stock is at the intersection of a northeast-trending mineral belt, a wide zone of shearing, and a postulated north-trending major shear zone whose presence is inferred from 
considerations relating to the origin of the Williams Range thrust fault (p. C27). There is little doubt that emplacement of the stock caused additional faulting or, at least, caused major and minor adjustments along existing faults. However, abundant fracturing within the stock indicates a continuation of faulting after emplacement and consolidation of the stock and indicates a continuation of the same kinds of dislocations that preceded the emplacement of the stock.

\section{PETROGRAPHY}

In surfaces exposures, the quartz monzonite is pinkish gray and is a mixture of flesh-colored crystals of orthoclase and light-gray plagioclase (in nearly equal proportions), and abundant quartz. Orthoclase crystals are $15-20 \mathrm{~mm}$ long, but porphyritic varieties are $20-50 \mathrm{~mm}$ across (fig. 29). Smoky quartz and plagioclase commonly occur as crystals $3-5 \mathrm{~mm}$ long. Biotite forms as scattered black hexagonal crystals about $2.5 \mathrm{~mm}$ in diameter.
Under the microscope, essential minerals are slightly perthitic orthoclase, zoned oligoclase, and quartz in a hypautomorphic-granular assemblage (fig. 29A). Biotite is a varietal accessory; magnetite, titanite, apatite, hornblende, and zircon are minor accessories. The orthoclase forms simple or Carlsbad-twinned, anhedral, nearly equant unzoned crystals containing tiny exsolved veinlets of albite. In contrast, the plagioclase is zoned and is generally euhedral to subhedral and shows albite, Carlsbad, and pericline twins. Feldspars in thin sections from several parts of the stock have extinction angles that indicate that the composition of the zones in the plagioclase ranges from calcic oligoclase $\left(\mathrm{An}_{28}\right)$ in the center of the crystals to intermediate oligoclase $\left(A n_{18}\right)$ in the outer zones. Biotite is in part converted to chlorite, and minor hornblende locally is altered to epidote. Titanite crystals are euhedral, wedge shaped, and as much as $0.5 \mathrm{~mm}$ long. Photomicrographs of thin sections of the quartz monzonite and quartz monzonite porphyry are shown in figure 29.
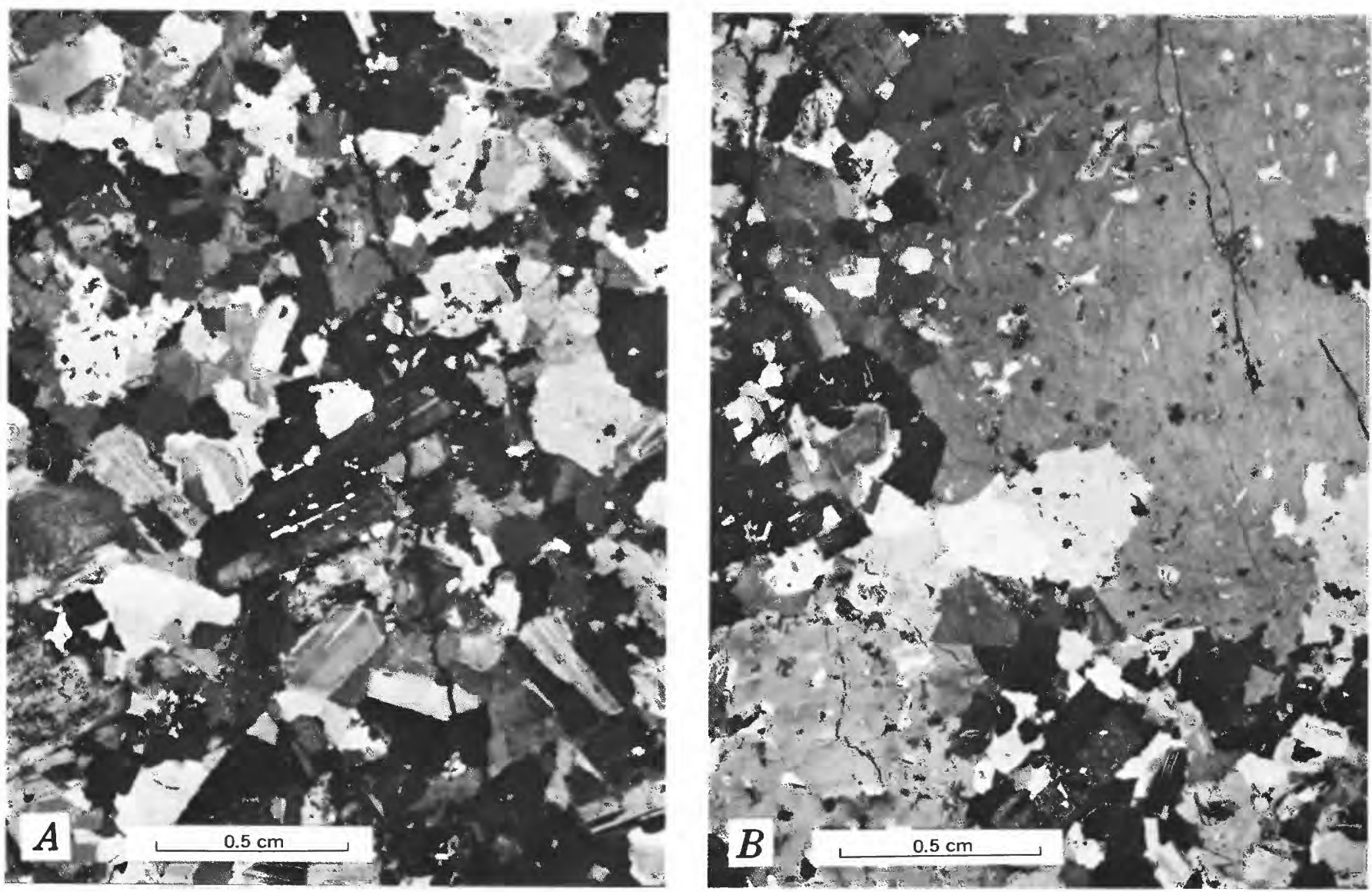

Figure 29. - Photomicrographs of Montezuma Quartz Monzonite. Crcssed polars. A, Quartz monzonite from station 389+00. B, Quartz monzonite porphyry from station $522+40$; large dark-gray area is orthoclase phenocrysts poikilitically enclosing plagioclase and dark minerals. 
A mode determined by 19,149 point counts of 30 thin sections of nonporphyritic quartz monzonite from the tunnel is given in table 3 . The rock could be called "biotite granodiorite" according to some classifications, but the term "quartz monzonite" is retained to correlate the rock with the rocks of identical fabric and mineralogy of the Mount Princeton batholith of central Colorado described by Crawford (1924) and classified by him as "Princeton quartz monzonite."

The aplite in dikes and gradational bodies within and at the southeast contact of the Montezuma stock with Precambrian rocks is an equigranular to somewhat porphyritic, brittle, fine-grained aggregate of quartz, slightly perthitic orthoclase and plagioclase, and minor amounts of biotite and magnetite, titanite, and apatite. The major components form a mosaic of anhedral crystals that average from 0.3 to $1.5 \mathrm{~mm}$ in diameter (figs. $30 A$, $30 \mathrm{~B}$ ). The plagioclase is inconspicuously zoned and ranges in composition from sodic andesine $\left(\mathrm{An}_{34}\right)$ to intermediate oligoclase $\left(\mathrm{An}_{20}\right)$. Biotite, magnetite,
TABLE 3.-Average modes (in volume percent) of Montezuma Quartz Monzonite and aplite

\begin{tabular}{|c|c|c|}
\hline & Quartz Monzonite ${ }^{1}$ & Aplite $^{2}$ \\
\hline Quartz & 26.1 & 34.2 \\
\hline Orthoclase & 26.5 & 39.7 \\
\hline Plagioclase ....... & 38.4 & 23.5 \\
\hline Biotite & 6.6 & 2.1 \\
\hline Magnetite ........... & 1.0 & 0.4 \\
\hline Titanite................. & 0.5 & $\ldots \ldots \ldots$. \\
\hline Apatite & 0.2 & $\ldots \ldots$ \\
\hline Hornblende ...... & 0.6 & ........ \\
\hline \multirow[t]{2}{*}{ Others } & 0.1 & 0.1 \\
\hline & 100.0 & 100.0 \\
\hline
\end{tabular}

'Average of 30 thin sections.

${ }^{2}$ Average of 4 thin sections.

titanite, and apatite appear as euhedral to subhedral crystals within and along grain boundaries of the major constituents. A mode determined by 3,421 point counts of four samples of aplite is given in table 3 . Figure 30 shows photomicrographs of two varieties of aplite.
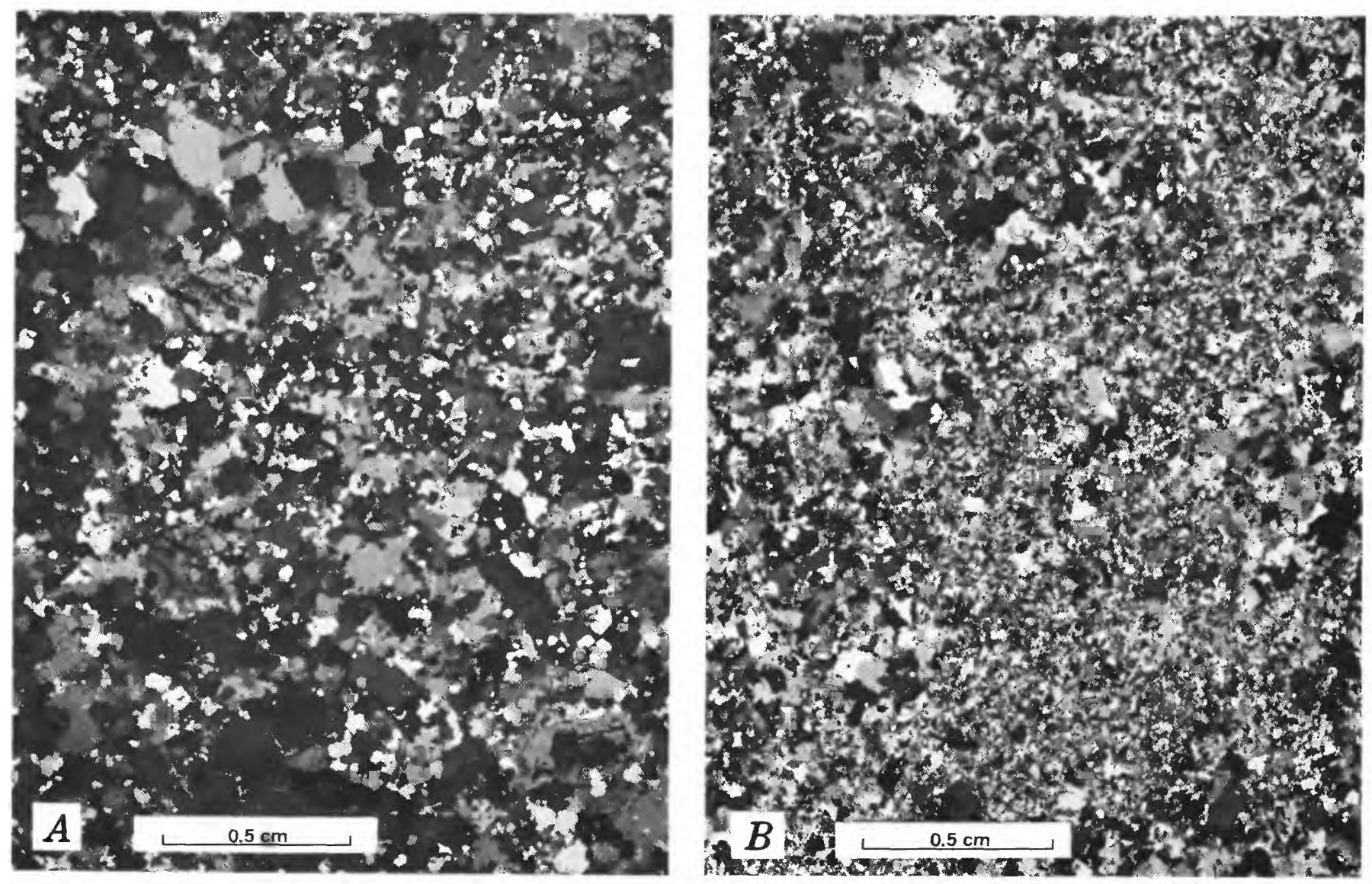

FIGURE 30.-Photomicrographs of aplite from Montezuma Quartz Monzonite. Crossed polars. A, Inequigranular aplite from station $460+45$. B, Aplite from station $617+18$. 


\section{STRUCTURAL GEOLOGY}

FAULTS, VEINS, AND JOINTS

Faults, veins, and joints in the Montezuma stock and in the enclosed Precambrian rocks have a variety of attitudes and where encountered in the tunnel produced extensively fractured, blocky rock that required nearly continuous support during the tunneling operation. Between stations $343+00$ and $690+00,1,447$ faults and veins and 2,485 strong joints were mapped. Minor joints, especially those associated with faults, were not recorded on maps because of their close spacing and random attitudes.

The tunnel interval between stations $343+00$ and $690+00$ was divided arbitrarily into eight sections for the purpose of making comparative analyses of the fracture patterns by means of equal-area plots (pl. 1). (Fractures as defined here include joints and small faults.) Figures 31 to 38 show fractures corresponding to maxima on the equal-area plots as related to the course of the tunnel. Table 4 summarizes the fracture-pattern data for the eight sections and gives the stationing of the tunnel

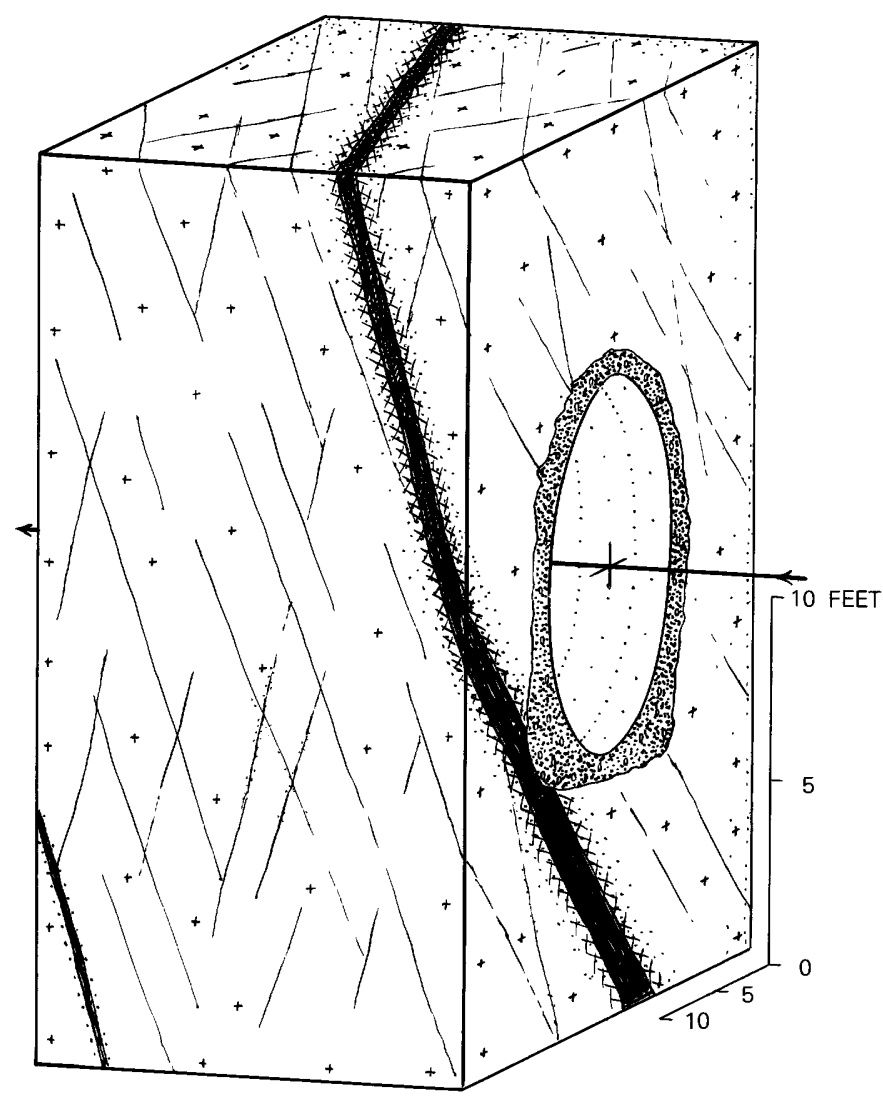

Figure 31.-Diagram showing statistical relationships of tunnel and fractures in quartz monzonite between stations $343+00$ and $384+83$. Arrow indicates direction of tunnel heading (N. $75^{\circ} 59^{\prime}$ W.).

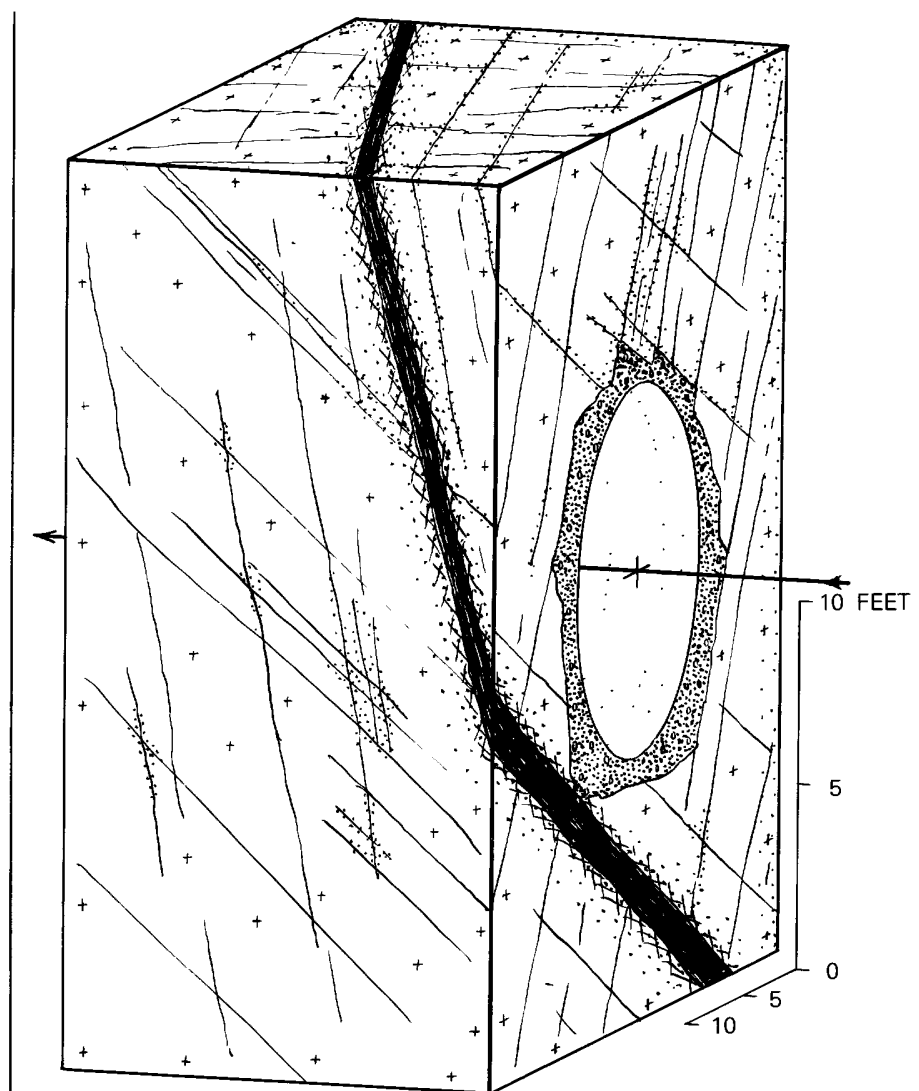

FIGURE 32.-Diagram showing statistical relationships of tunnel and fractures in quartz monzonite between stations $384+83$ and 426+66. Arrow indicates direction of tunnel heading (N. $75^{\circ} 59^{\prime}$ W.).

intervals included in each section and the maxima of 6 percent or more that appear on the equal-area plots on plate 1 between stations $343+00$ and $690+00$. Figure 39 shows the several fracture maxima on a single diagram, and for comparison, the trends of the tunnel, N. $75^{\circ} 59^{\prime} \mathrm{W}$. for the Dillon heading and S. $49^{\circ} 33^{\prime}$ E. for the Grant heading. Strikes of steeply dipping fault and vein maxima also are indicated.

The fault, vein, and joint maxima fall into three areas on the plot in figure 39. Area 1 includes poles of maxima for steeply dipping fractures striking between $\mathrm{N}$. $35^{\circ} \mathrm{W}$. and $\mathrm{N}$. $13^{\circ} \mathrm{E}$. Slickensides observed on faults that have attitudes within these limits commonly are parallel to the dip. The average strike approximates that of the surface trace of the Williams Range thrust fault on the west side of the Front Range, and the fractures apparently represent movements that accompanied the uplift of the Front Range after the emplacement of the Montezuma stock. Area 2 contains fault and vein maxima for gently dipping faults that caused considerable overbreak in the section between stations $500+00$ and 
TABLE 4.-Fracture maxima between stations $343+00$ and $690+00$

\begin{tabular}{|c|c|c|c|}
\hline Section & Stations & Fault and vein maxima & Joint maxima \\
\hline \multicolumn{4}{|c|}{ Tunnel bearing: S. $75^{\circ} 59^{\prime} \mathrm{E}$. } \\
\hline 1 & $343+00$ to $384+83$ & (1) N. $2^{\circ}$ E.; $76^{\circ}$ E.;24.3percent & $\begin{array}{l}\text { (1) N. } 3^{\circ} \text { W.; } 70^{\circ} \text { E.; } 11.8 \text { percent } \\
\text { (2) N. } 40^{\circ} \text { E.; } 78^{\circ} \text { NW.; } 6 \text { percent }\end{array}$ \\
\hline 2 & $384+83$ to $426+66$ & (1) N. $2^{\circ}$ W.; $76^{\circ}$ E.; 15.4 percent & $\begin{array}{l}\text { (1) N. } 80^{\circ} \text { E.; } 66^{\circ} \text { S.; } 10 \text { percent } \\
\text { (2) N. } 2^{\circ} \text { E.; } 78^{\circ} \text { E.;6 percent }\end{array}$ \\
\hline 3 & $426+66$ to $468+49$ & $\begin{array}{l}\text { (1) N. } 35^{\circ} \text { W.; } 78^{\circ} \text { NE.; } 9.3 \text { percent } \\
\text { (2) N. } 2^{\circ} \text { E.; } 66^{\circ} \text { E.; } 8 \text { percent }\end{array}$ & (1) N. $70^{\circ}$ E.; $64^{\circ} \mathrm{SE} . ; 7.1$ percent \\
\hline \multicolumn{4}{|c|}{ Tunnel bearing: S.49 ${ }^{\circ} 33^{\prime} \mathrm{E}$. } \\
\hline 4 & $468+49$ to $500+00$ & $\begin{array}{l}\text { (1) N. } 14^{\circ} \text { E.; } 74^{\circ} \mathrm{SE} . ; 12.4 \text { percent } \\
\text { (2) N. } 30^{\circ} \mathrm{W} . ; 80^{\circ} \mathrm{NE} \text {.; } 6 \text { percent }\end{array}$ & $\begin{array}{l}\text { (1) N. } 30^{\circ} \mathrm{W} . ; 78^{\circ} \mathrm{NE} . ; 8.7 \text { percent } \\
\text { (2) N. } 44^{\circ} \text { E.; } 44^{\circ} \text { NW.; } 6 \text { percent }\end{array}$ \\
\hline 5 & $500+00$ to $550+00$ & $\begin{array}{l}\text { (1) N. } 54^{\circ} \text { E.; } 73^{\circ} \mathrm{SE} . ; 15.1 \text { percent } \\
\text { (2) N. } 36^{\circ} \text { W.; } 10^{\circ} \mathrm{SW} . ; 6 \text { percent } \\
\text { (3) N. } 9^{\circ} \text { W.; } 80^{\circ} \text { E.; } 6 \text { percent }\end{array}$ & $\begin{array}{l}\text { (1) N. } 54^{\circ} \text { E.; } 76^{\circ} \mathrm{SE} . ; 15.5 \text { percent } \\
\text { (2) N. } 12^{\circ} \text { E.; } 80^{\circ} \mathrm{SE} . ; 8 \text { percent }\end{array}$ \\
\hline 6 & $550+00$ to $600+00$ & (1) N. $66^{\circ}$ E.; $90^{\circ} ; 15$ percent & $\begin{array}{l}\text { (1) N. } 14^{\circ} \text { W.; } 78^{\circ} \mathrm{NE} . ; 14.6 \text { percent } \\
\text { (2) N. } 68^{\circ} \text { E.; } 90^{\circ} ; 14 \text { percent }\end{array}$ \\
\hline 7 & $600+00$ to $650+00$ & $\begin{array}{l}\text { (1) N. } 50^{\circ} \text { E.; } 67^{\circ} \mathrm{NW} . ; 14 \text { percent } \\
\text { (2) N. } 85^{\circ} \text { E.; } 20^{\circ} \mathrm{SE} . ; 6 \text { percent }\end{array}$ & $\begin{array}{l}\text { (1) N. } 16^{\circ} \text { W.; } 72^{\circ} \mathrm{NE} . ; 8.6 \text { percent } \\
\text { (2) N. } 55^{\circ} \text { E.; } 70^{\circ} \mathrm{NW} . ; 8 \text { percent } \\
\text { (3) N. } 85^{\circ} \text { W.; } 82^{\circ} \mathrm{SW} . ; 6 \text { percent } \\
\text { (4) N. } 78^{\circ} \text { E.;58 } 58^{\circ} \text { NW.;6 percent }\end{array}$ \\
\hline 8 & $650+00$ to $690+00$ & $\begin{array}{l}\text { (1) N. } 72^{\circ} \text { E.; } 65^{\circ} \mathrm{NW} . ; 20 \text { percent } \\
\text { (2) N. } 4^{\circ} \text { E.; } 65^{\circ} \text { W.; } 8 \text { percent } \\
\text { (3) N. } 28^{\circ} \text { E.; } 82^{\circ} \text { NW.;8 percent }\end{array}$ & $\begin{array}{l}\text { (1) N. } 78^{\circ} \mathrm{E} . ; 67^{\circ} \mathrm{NW} . ; 14.4 \text { percent } \\
\text { (2) North; } 67^{\circ} \mathrm{W} . ; 14 \text { percent }\end{array}$ \\
\hline
\end{tabular}

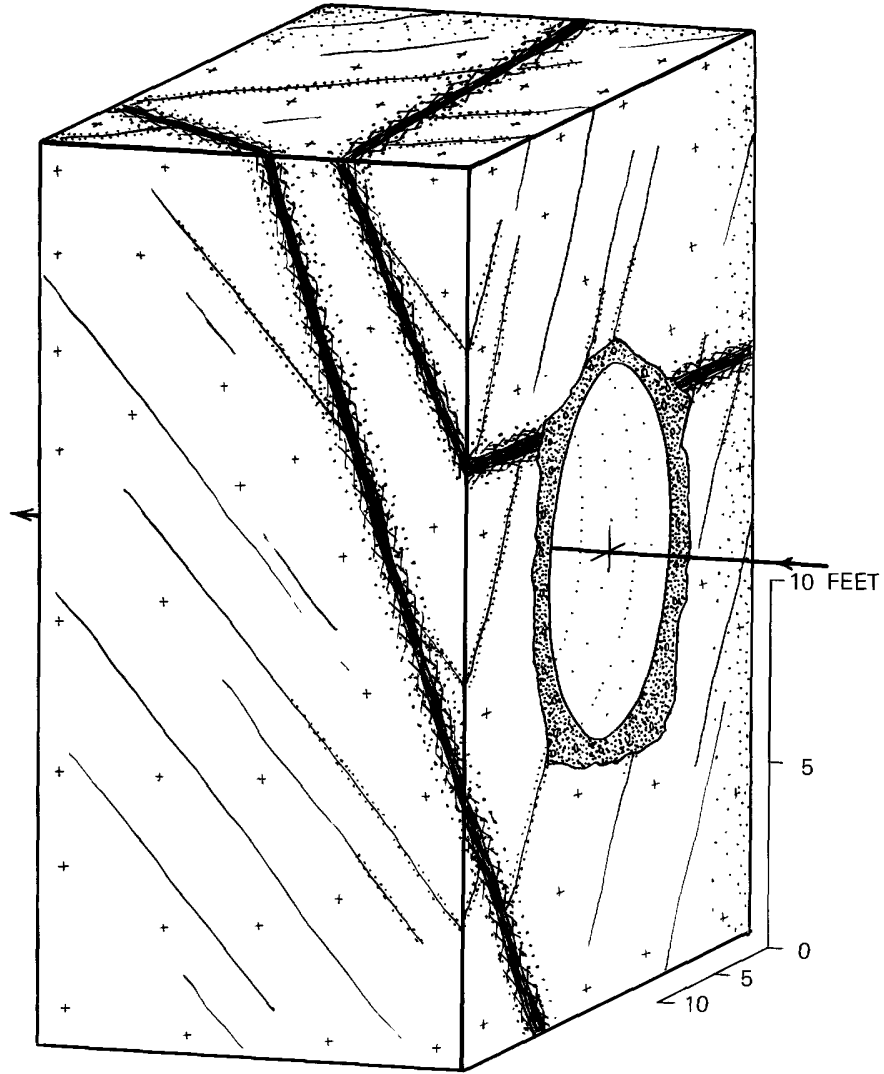

FIGURE 33.-Diagram showing statistical relationships of tunnel and fractures in quartz monzonite between stations $426+66$ and $468+49$. Arrow indicates direction of tunnel heading (N. $75^{\circ} 59^{\prime}$ W.).

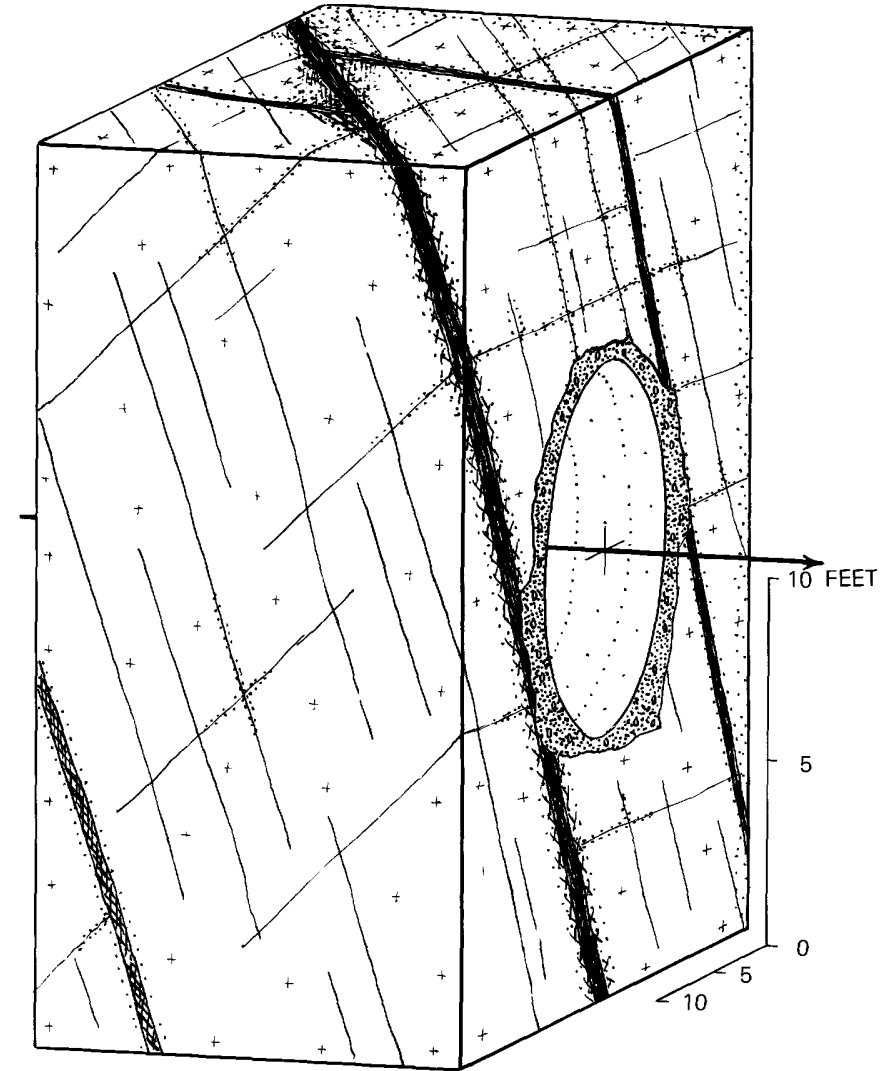

FIGURE 34.-Diagram showing statistical relationships of tunnel and fractures in quartz monzonite between stations $468+49$ and $500+00$. Arrow indicates direction of tunnel heading (S. $75^{\circ} 59^{\prime}$ E.). 


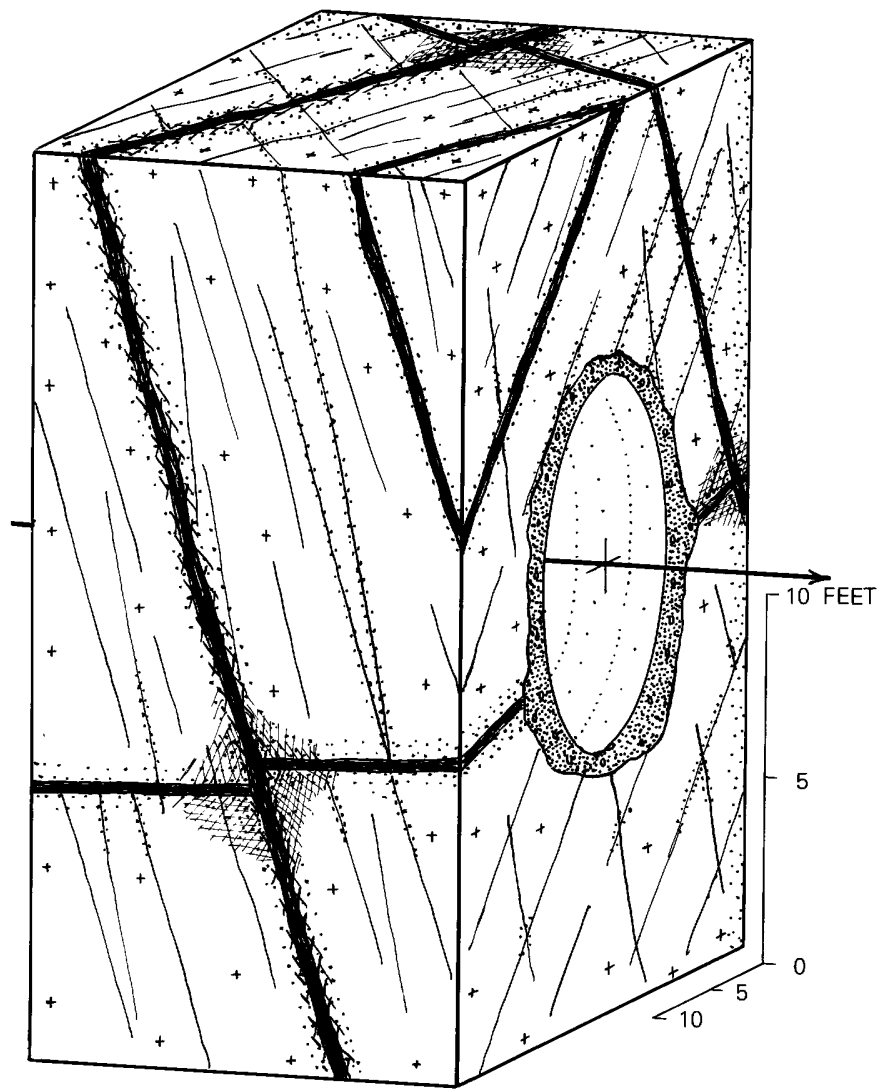

FIGURE 35.-Diagram showing statistical relationships of tunnel and fractures in quartz monzonite between stations $500+00$ and $550+00$. Arrow indicates direction of tunnel heading (S. $49^{\circ} 33^{\prime}$ E.).

$550+00$ and less overbreak between stations $600+00$ and $650+00$. Extensive argillic alteration that accompanied the gently dipping faults destroyed evidence of the direction of movement, but the gently dipping faults terminate against steeply dipping north-trending faults with pole maxima in area 1. The gently dipping faults probably represent adjustments that accompanied dislocations along the steep faults.

Faults and veins with maxima in area 3 are nearly at right angles to the tunnel and slickensides observed in a few exposures generally are approximately horizontal. The faults and veins in area 3 formed by movements in the Montezuma stock that are related to the displacements along the Front Range mineral belt and are in line with the belt where it is exposed northeast and southwest of the stock. The time relationship between the northeasttrending and the north-trending faults is not known with certainty, but many north-trending fractures near the west contact of the stock contain aplite and probably formed immediately after the emplacement and consolidation of the stock.

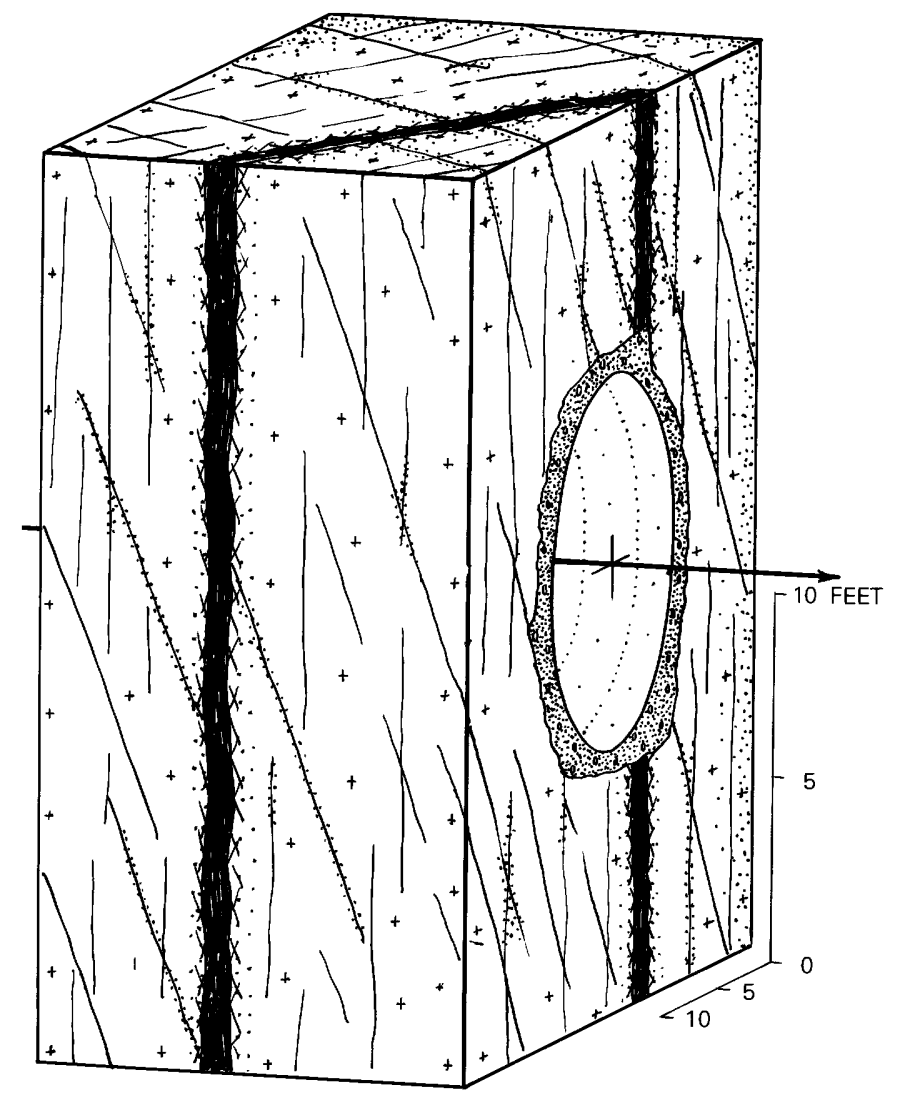

FiguRE 36.-Diagram showing statistical relationships of tunnel and fractures in quartz monzonite between stations $550+00$ and $600+00$. Arrow indicates direction of tunnel heading (S. $49^{\circ} 33^{\prime}$ E.).

The equal-area plots on plate 1 between stations $343+00$ and $690+00$ in figures $31-38$ indicate the attitudes of fracture concentrations relative to the directions in which the tunnel was driven. The tunnel was advanced N. $75^{\circ} 59^{\prime} \mathrm{W}$. in the Dillon heading from the access shaft and intersected many faults dipping steeply into the tunnel from the heading and crossing the tunnel at angles ranging from $40^{\circ}-75^{\circ}$ to the centerline (pl. 1 , stas. $343+00$ to $500+00$; figs. 31-33). The Grant heading, driven S. $49^{\circ} 33^{\prime}$ E. from an angle point east of the access shaft, intersected many steeply dipping faults that crossed the tunnel at angles between $20^{\circ}$ and $80^{\circ}$ to the centerline as far as station $550+00$ (pl. 1; figs. 34 , 35). Southeast of station $550+00$ to the limit of the Montezuma stock, the tunnel penetrated the northeast-trending mineral belt and intersected faults and veins most of which cross the tunnel nearly at right angles (figs. 36-38), a circumstance generally favorable to the progress of the tunnel heading. 


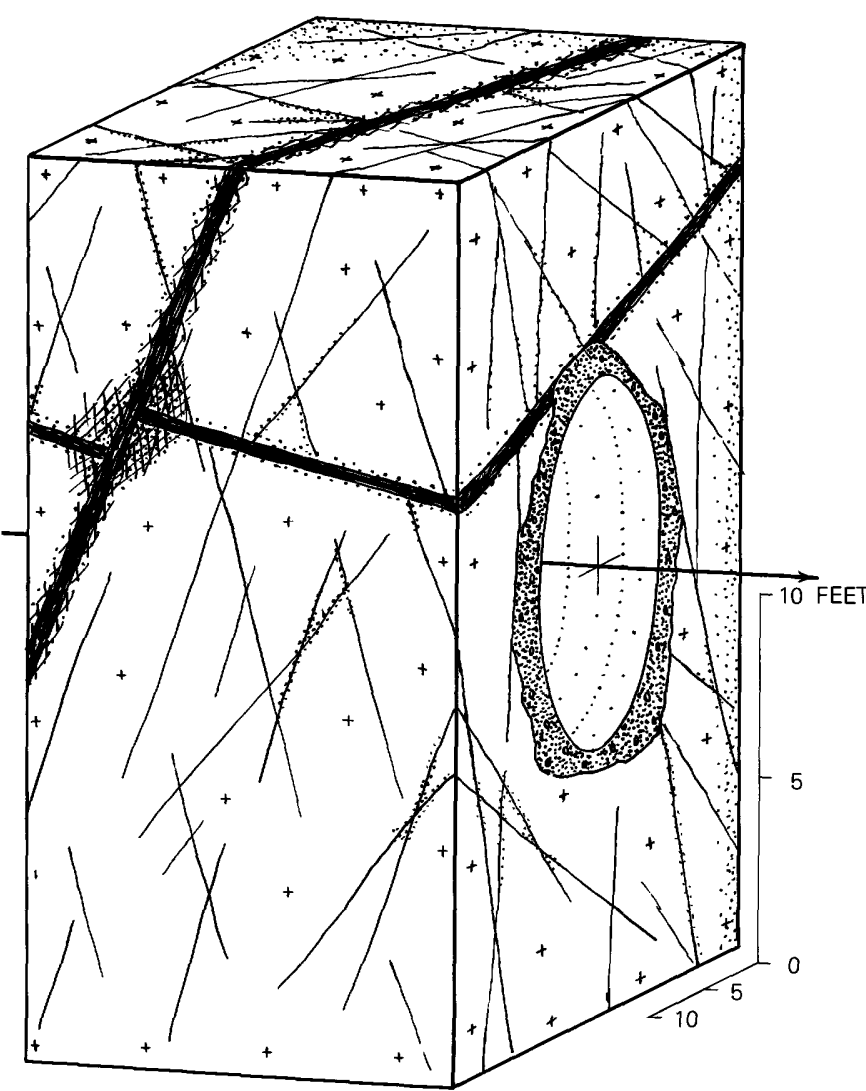

Figure 37.-Diagram showing statistical relationships of tunnel and fractures in quartz monzonite between stations $600+00$ and $650+00$. Arrow indicates direction of tunnel heading (S. $49^{\circ} 33^{\prime}$ E.).

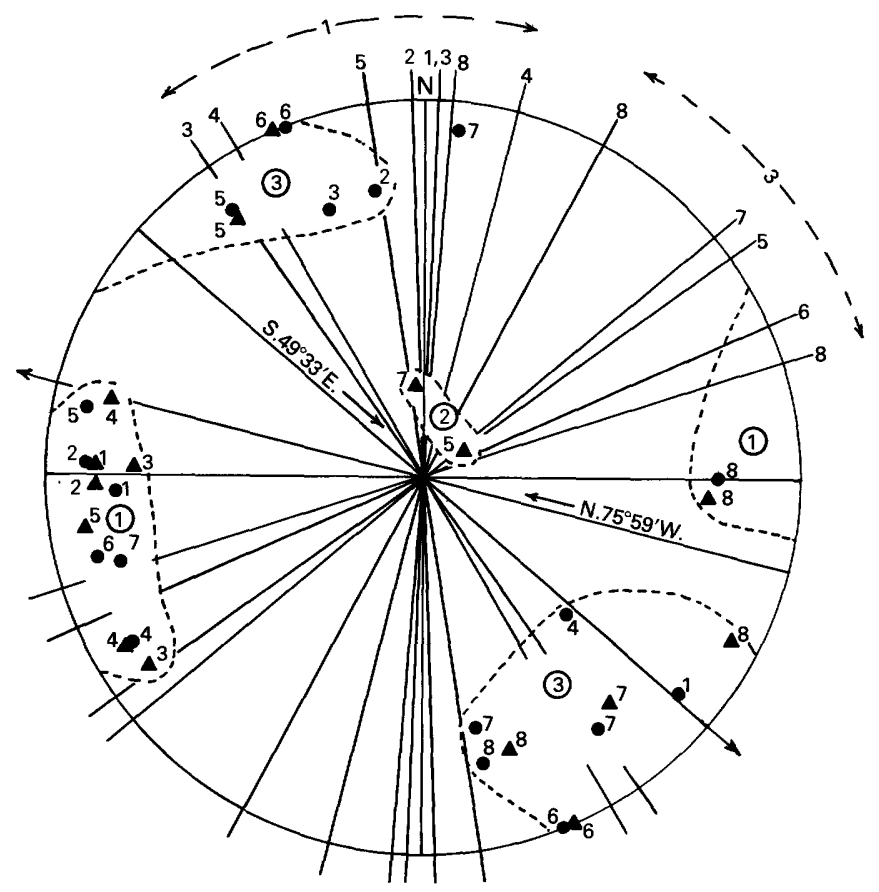

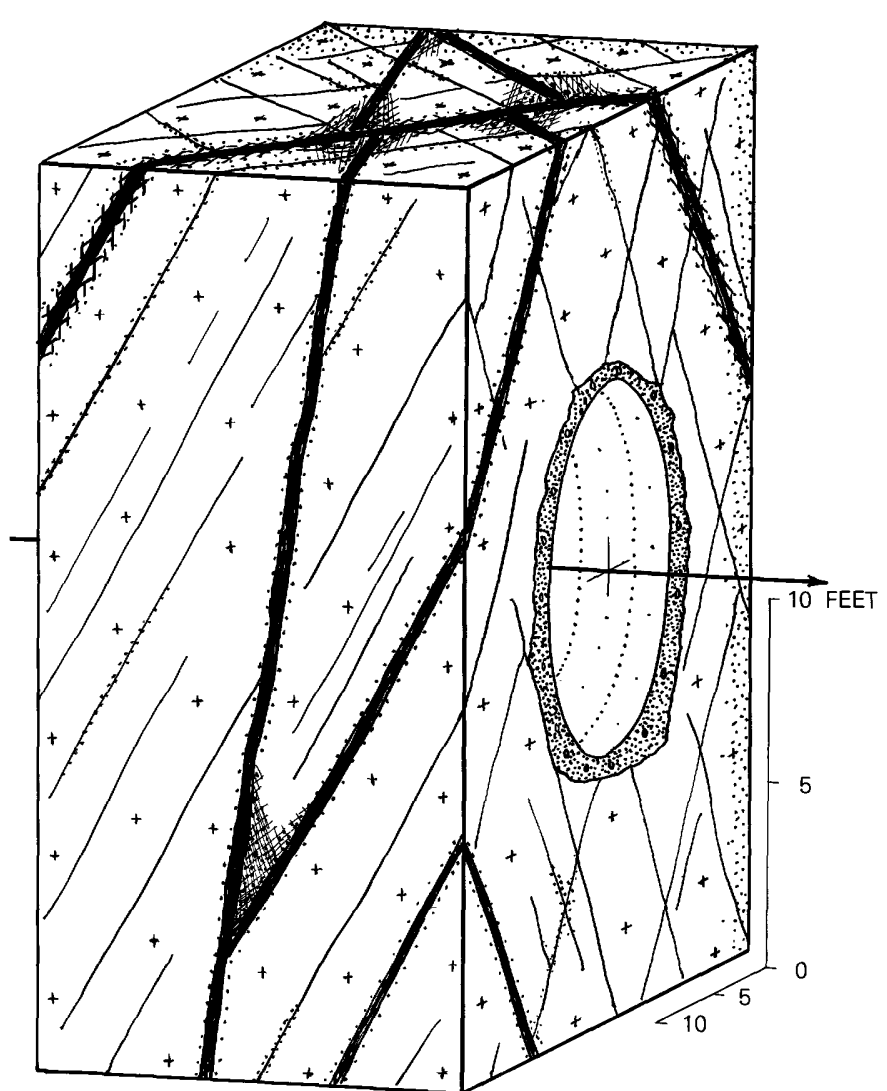

FIGURE 38.-Diagram showing statistical relationships of tunnel and fractures in quartz monzonite between stations $650+00$ and $690+00$. Arrow indicates direction of tunnel heading (S. $49^{\circ} 33^{\prime}$ E.).
Figure 39.-Equal-area plot of fault, vein, and joint maxima (lower hemisphere). Triangles, fault and vein maxima; solid circles, joint maxima. Strike of fault and vein maxima also are shown. Circled numbers refer to area discussed in text. Numbers adjacent to triangles and circles identify tunnel intervals as follows:
1. Stations $343+00$ to $384+83$.
2. Stations $384+83$ to $426+66$.
3. Stations $426+66$ to $468+49$ (angle point).
4. Stations $468+49$ to $500+00$.
5. Stations $500+00$ to $550+00$.
6. Stations $550+00$ to $600+00$.
7. Stations $600+00$ to $650+00$.
8. Stations $650+00$ to $690+00$ 


\section{ORE MINERALIZATION AND WALLROCK ALTERATION}

Veins containing a variety of ore and gangue minerals and accompanied by more or less intense wallrock alteration are present in all parts of the stock intersected by the Roberts Tunnel, but special concentrations of veins were noted in the tunnel between stations $500+00$ and $800+00$, where the stock and adjacent rocks are crossed by the Colorado mineral belt. Argillic alteration is more widespread than ore mineralization and many fractures that localized intense wallrock alteration are barren or contain only quartz and carbonates.

The quartz monzonite in all parts of the Montezuma stock contains sparse, scattered, tiny plates of molybdenite, but only two veins containing concentrations of molybdenite were noted in the tunnel. A lenticular vein with a maximum width of 6 inches at station $440+22$, west of the access shaft, contained glassy quartz, minor amounts of pyrite, and scattered clusters of molybdenite plates as much as half an inch in diameter. A similar 4-inch vein, which contains abundant cubic pyrite, molybdenite, and minor amounts of late flesh-colored crystals of rhodochrosite in vugs, was observed at station $612+95$.

Pyrite is abundant in disseminations and as tiny veinlets in rocks adjacent to and included in the stock; it formed by mineralizing solutions spreading outward along myriads of closely spaced intersecting joints. Similar disseminations and joint fillings are locally present in the stock near its southeast contact with Precambrian gneiss.

\section{VEINS}

The poles of 394 veins between stations $460+00$ and $800+00$ were plotted on a Schmidt net and contoured with a 1-percent counter. The resulting diagram is shown in figure 40 . The attitudes of the veins range widely but most of them strike northeast. Several veins strike in a northerly direction; very few strike northwest. Although the number of northeasttrending fractures greatly exceeds that of the northtrending fractures, figure 40 indicates that most, perhaps all, of the major sets of fractures in the Montezuma stock indicated in figure 39 were present before the advent of ore mineralization and wallrock alteration. Movement along some veins after mineralization resulted in crushing and brecciation of the vein fillings and formation of gouge containing pulverized sulfide minerals. Some veins contain breccia of early vein minerals surrounded by later ore and gangue minerals; and, considering all evidence, it seems clear that mineralization was

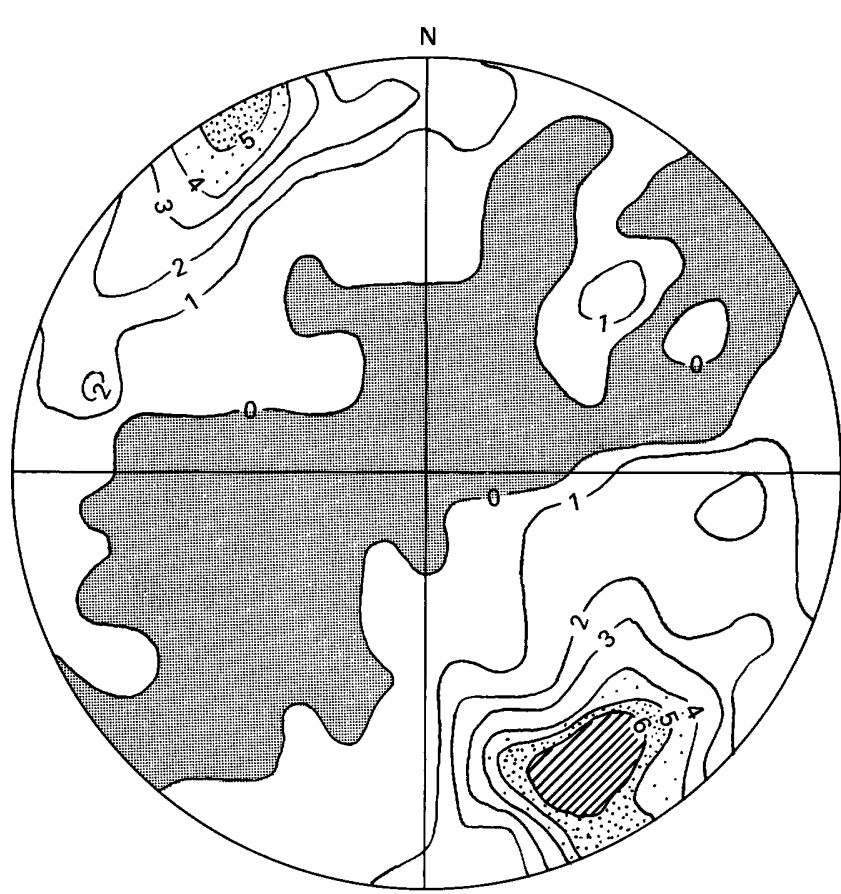

Figure 40.-Contoured equal-area plot (lower hemisphere of poles of 394 veins between stations $460+00$ and $800+00$. Maximum of 6.3 percent corresponds to a strike of $\mathrm{N} .62^{\circ} \mathrm{E}$. and a dip of $70^{\circ} \mathrm{NW}$.

preceded, accompanied, and followed by intermittent dislocations along the mineralized fractures.

\section{MINERALOGY}

Lovering (1935) summarized the occurrence of minerals in the Montezuma quadrangle. All mineral deposits encountered in the Roberts Tunnel are well below the zone of oxidation and consist only of aggregates of primary ore and gangue minerals formed as fracture fillings and by pyritic replacement of the wallrocks.

Ore and gangue minerals differ in kind and amount from vein to vein and from place to place in a single vein. Some veins are crustified and contain at least one of layered ore and gangue minerals. Repeated sequences indicate pulsating mineralizing solutions and complex and, locally, intermittent penetration of fractures by the solutions, probably in response to structural changes in channelways resulting from dislocations during mineralization.

Between stations $400+00$ and $600+00$, approximately, abundant sulfide minerals in the veins are pyrite, sphalerite, chalcopyrite, and galena. The gangue minerals are quartz and late dolomite. Minor amounts of prismatic marcasite were noted 
in a specimen from station $495+85$. The sphalerite is iron rich (marmatite), is zoned, and contains tiny exsolved blebs of chalcopyrite in all samples that were examined.

A generalized paragenetic diagram for the ore and gangue minerals in the quartz-sulfide veins between stations $400+00$ and $600+00$ is shown in figure $41 \mathrm{~A}$.

Southeast of station $600+00$ (approximately), rhodochrosite, anhydrite, dolomite, and gypsum are abundant in some veins. Sulfides are pyritohedral pyrite, sphalerite, and in minor amounts molybdenite and galena. The rhodochrosite and the dolomite are zoned and formed by pulsating deposition in open fractures. The sphalerite is lighter colored than it is in veins northwest of station $600+00$; it contains abundant quartz and other sulfides. Crustification is locally conspicuous and enables determination of the generalized paragenetic sequence indicated in figure $41 B$.

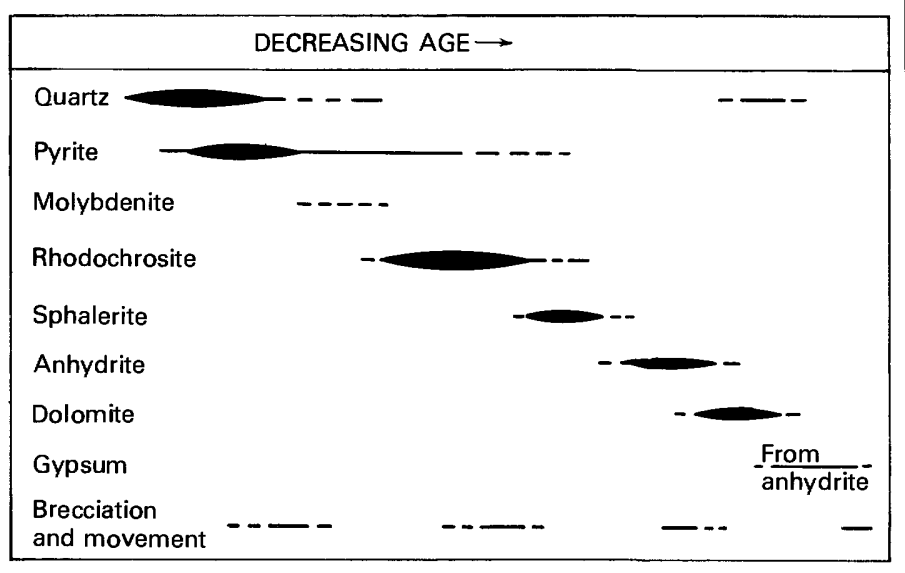

A

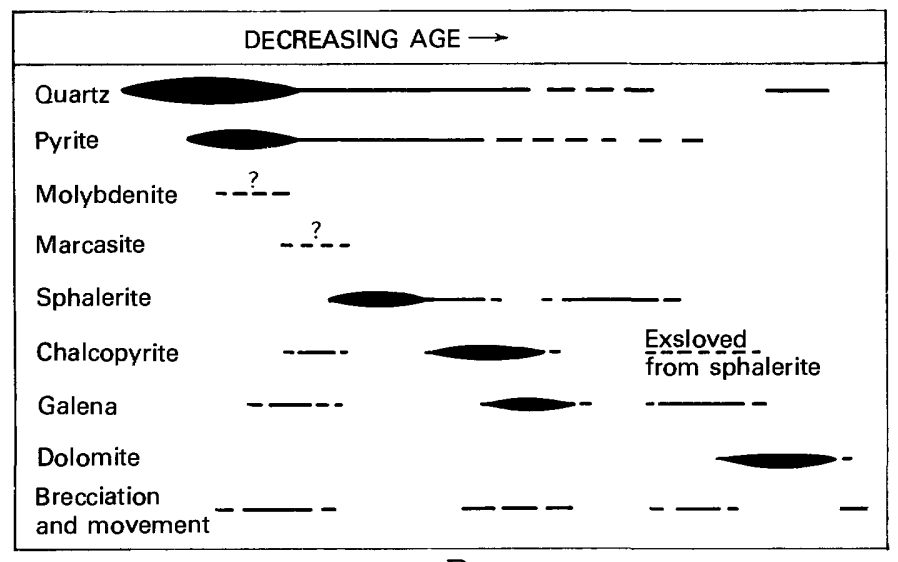

B

FIGURE 41-Paragenetic diagrams of veins. $A$, Quartz-sulfide veins. $B$, Rhodochrosite-sphalerite-anhydrite veins.
Gypsum, in large clear plates, some as much as 6 inches across, is seen in thin-section to have formed from anhydrite by hydration, and it apparently is the latest hypogene mineral in the veins. Sulfarsenides and sulfantimonides of copper and silver that are present in some of the veins mined from the surface in the Montezuma stock and adjacent rocks were not observed in any of the numerous samples collected from tunnel level; however, this absence does not preclude the possibility of their presence in some of the veins. The vast majority of veins, nevertheless, are virtually barren of precious elements and, considering their narrow widths and lenticularity, must be regarded as of no economic value at the present time.

\section{WALLROCK ALTERATION}

Many faults and joints in the Montezuma stock are accompanied by argillic alteration that is zoned and extends from a fraction of an inch to several feet into the wallrock adjacent to fractures. the outermost zone contains chlorite formed from biotite, and sparse sericite formed by alteration of oligoclase. The chloritic alteration generally is patchy and erratic and is not everywhere evident. Inside the chlorite zone, feldspars (especially oligoclase), have been partly to completely altered to clayey aggregates of montmorillonite and kaolinite, and also sparse sericite. Moisture from the tunnel air caused slow swelling of the rocks that contained montmorillonite and in time caused the rocks to break apart as sticky clay masses mixed with angular fragments of unaltered rock. Fine-grained quartz and sericite (a disordered 1-layer muscovite) have been introduced and have replaced montmorillonite-kaolinite assemblages next to some of the fractures to form a narrow inner zone rarely more than a few inches wide. Silicification and sericitization next to fractures is especially noteworthy where the fractures contain sulfides and is likely to be absent where the fracture fillings consists only of quartz and (or) carbonates.

The montmorillonite-kaolinitealteration presented a major problem in the tunneling operation. Thin selvages of argillic alteration formed along even hairline cracks in most parts of the Montezuma stock and promoted collapse of joint blocks that, in the absence of the alteration, would have remained keyed into the arch of the tunnel. Rock broken by blasting contained many blocks bounded by intersecting surfaces coated with a very thin smooth layer of greasy clay minerals. These minerals were present in just sufficient amount to destroy the 
originally rough surfaces or, at the least, to permit smooth shearing along the rough surfaces so as to practically eliminate any appreciable friction between adjacent joint blocks.

All gradations exist between fresh, unaltered rock and completely altered rock which occurs in wide zones. The wide zones of argillic alteration formed where altering solutions spread out through closely fractured rocks and the faults that intersect them. The pervasively altered rocks, on first exposure, generally had a full waxy appearance; plagioclase crystals contained in the altered rocks had completely changed to white or gray aggregates of clay minerals. Muck or the tunnel floor quickly changed to a sticky mass of mud mixed with angular fragments of unaltered rock. Altered rocks in the walls and arch gradually absorbed moisture from the tunnel air and slowly slacked off into the tunnel or, by expanding, exerted considerable pressure on timber and steel supports (figs. 42, 43).

Several samples of argillized quartz monzonite were collected from the tunnel and analyzed in the laboratory by methods described by Lambe (1960) for the study of expansive soils. Tests were preformed with an instrument identified as a "Soil PVC Meter" (Soil potential volume change meter), which measures volume changes and pressures as water is added to soil samples. The method was developed for appraisal of soils in foundations and includes a classification or rating (PVC rating) which gives a measure of the desirable or undesirable characteristics of soils in foundations.

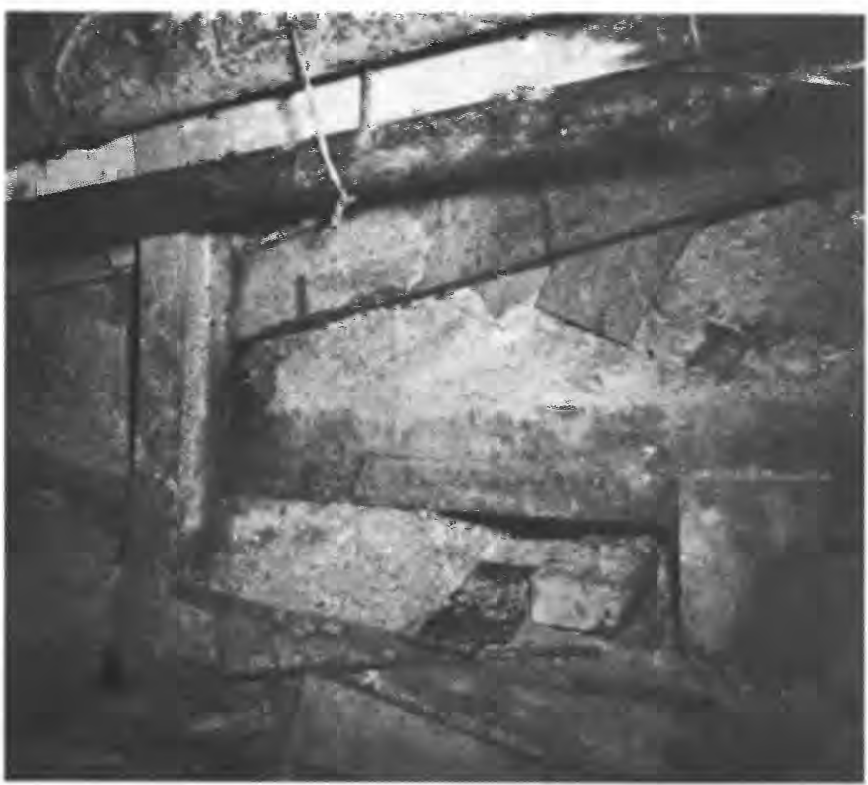

FIGURE 42.-Altered, squeezing Montezuma Quartz Monzonite at station $428+25$

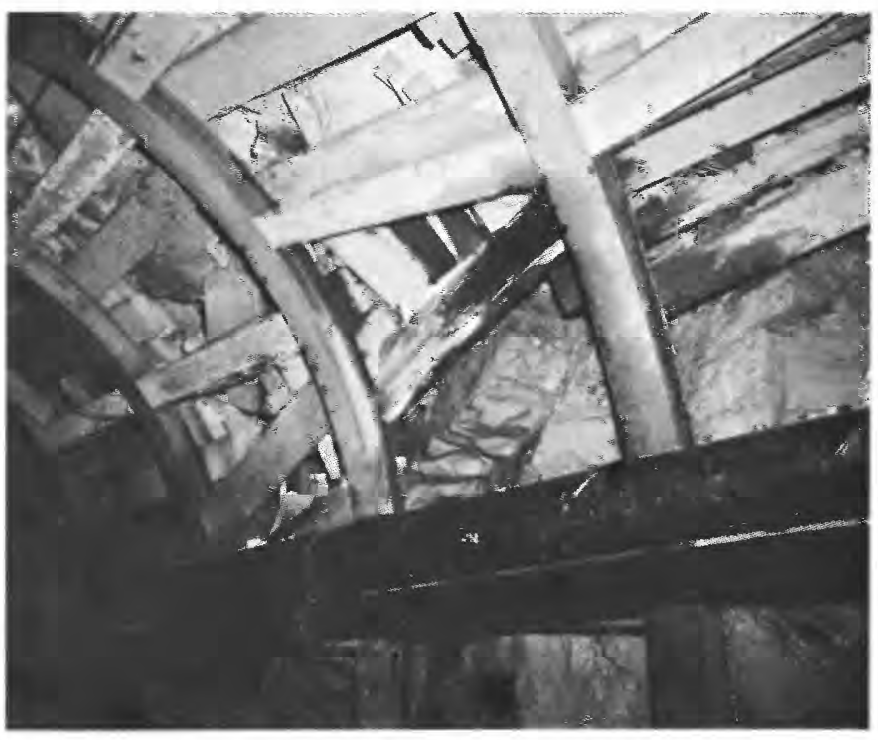

Figure 43.-Altered, squeezing Montezuma Quartz Monzonite near station $500+00$. Note broken lagging.

Table 5 presents a summary of the results of the examination of argillized quartz monzonite samples from the tunnel. The procedure followed is described by Wahlstrom, Robinson, and Nichols (1968). Particularly pertinent are the PVC swell indexes, measured in pounds per square foot, that were determined by additions of water to the crushed and sized samples. A PVC swell index of 9,890 psf (pounds per square foot) for the sample from station $530+90$ represents the maximum value and indicates the extent to which pressure was exerted on timber and steel supports by hydration of the argillized tunnel rocks. The effect of the swelling pressure on the supports was decreased somewhat by the fact that the swelling rock behaved plastically "and tended to squeeze into the tunnel through openings between the supports so that the total pressure of swelling was not completely transmitted to the supports. Nevertheless, in many parts of the tunnel, sufficient pressure was exerted on the supports to cause their slow dislocation or failure.

\section{ENGINEERING PRACTICES IN RELATION TO GEOLOGY}

The engineering practices used during construction of a tunnel are dictated to a large extent by the geologic conditions. The amount of overbreak is related to the attitudes and spacing of fractures and the alteration along and between fractures. The need for feeler holes to detect ground water and incompetent rock in advance of the face-and grouting off the ground water-is determined chiefly 


\begin{tabular}{|c|c|c|c|c|c|c|c|c|c|c|c|}
\hline \multirow[b]{2}{*}{ Station } & \multirow{2}{*}{$\begin{array}{c}\text { Swell } \\
\text { capacity } \\
\text { (milliliters) }\end{array}$} & \multirow{2}{*}{$\begin{array}{c}\text { PVC } \\
\text { swell } \\
\text { index } \\
\text { (psf) }\end{array}$} & \multirow[b]{2}{*}{$\begin{array}{l}\mathrm{PVC}^{\prime} \\
\text { rating }\end{array}$} & \multicolumn{8}{|c|}{ Mineralogy ${ }^{2}$} \\
\hline & & & & $\begin{array}{l}\text { Mont- } \\
\text { moril- } \\
\text { onite }\end{array}$ & $\begin{array}{l}\text { Kao- } \\
\text { linite }\end{array}$ & Mica & $\begin{array}{l}\text { K-feld- } \\
\text { spar }\end{array}$ & $\begin{array}{l}\text { Plagio- } \\
\text { clase }\end{array}$ & Quartz & $\begin{array}{l}\text { Carbon- } \\
\text { ate }\end{array}$ & Pyrite \\
\hline $399+20$ & 4.0 & 7,470 & $\begin{array}{c}8.6 \\
\text { very critical }\end{array}$ & $1^{*}$ & 6 & 4 & 5 & & 2 & 3 & \\
\hline $459+43$ & 3.8 & 6,730 & $\begin{array}{c}8.1 \\
\text { very critical }\end{array}$ & $1^{*}$ & 6 & 2 & 5 & & 3 & 4 & \\
\hline $473+75$ & 2.5 & 3,000 & $\begin{array}{c}3.7 \\
\text { marginal }\end{array}$ & 3 & 5 & 2 & $\left({ }^{2}\right)$ & $\left({ }^{2}\right)$ & 4 & & \\
\hline $510+00$ & 3.0 & 1,500 & $\begin{array}{c}1.7 \\
\text { noncritical }\end{array}$ & 2 & 5 & 4 & $\left({ }^{2}\right)$ & $\left({ }^{2}\right)$ & 3 & & \\
\hline $530+90$ & 3.5 & 9,890 & $\begin{array}{c}10.8 \\
\text { very critical }\end{array}$ & $1^{*}$ & 6 & 4 & 5 & & 3 & 2 & \\
\hline $545+50$ & 2.5 & 1,070 & $\begin{array}{c}1.2 \\
\text { noncritical }\end{array}$ & 4 & 3 & 2 & 6 & & ${ }^{*} 1$ & 5 & \\
\hline $569+80$ & 2.7 & 4,200 & $\begin{array}{c}5.3 \\
\text { critical }\end{array}$ & & $\ldots$ & 1 & & & 3 & & 2 \\
\hline $594+15$ & 2.5 & 520 & $\begin{array}{c}0.04 \\
\text { noncritical }\end{array}$ & & & 2 & & $\ldots$. & ${ }^{*} 1$ & & \\
\hline
\end{tabular}

IPVC: Soil Potential Volume change (Lambe, 1960).

${ }^{2} \mathrm{~K}$-feldspar and plagioclase feldspar are intergrown and exist as the predominant muneral.

by the extent and spacing of fractures. All the geologic factors dictated the support required. Progress was directly related to the amount of work required to stabilize the opening. (See graph on pl. 1)

\section{OVERBREAK}

The overbreak in the Montezuma Quartz Monzonite and associated aplite depended entirely on the attitudes and spacing of fractures and the extent and kind of alteration along and between fractures. Flow layering was very poorly developed and was observed in the stock in only a few places; the quartz monzonite is essentially an isotropic rock. Argillic alteration in many sections of the tunnel spread out for several feet into the walls adjacent to fractures and produced a soft waxy rock of slight strength. Sericitization and silicification along veins produced brittle zones superimposed on the argillic alteration and tended to increase the competency of the altered rocks.

Precambrian rocks in roof pendants and inclusions in the stock in general were not intensely fractured and required only light support-or none at all.
Overbreak, as related to geology in plan and section, is shown on plate 5 for several representative intervals of the Roberts Tunnel between stations $353+00$ and $688+40$. Figure 44 is a photograph of the tunnel in massive quartz monzonite and indicates the massive nature of rock that required.

Plate $5 A$ shows overbreak in an unsupported interval between stations $353+00$ and $354+40$. The tunnel was driven west from the access shaft through quartz monzonite that contains a swarm of thin (12- to 15-inch), steeply dipping aplite dikes. Joints are not numerous and are not accompanied by argillic alteration. An average overbreak of 9.3 percent in cross section was near the minimum.

The effects of closely spaced joints and slips accompanied by argillic alteration are indicated on plate $5 B$. Joints with apparent dips to the right (north) in the tunnel heading as the heading was advanced westward from station $419+40$ to station $418+00$ controlled the manner of breaking of the rock during blasting operations and resulted in considerable overbreak in the upper right portion of the tunnel. The average of 15 cross sections approximates a tilted ellipse in the arch. The longer axis of the ellipse is approximately perpendicular to the mean apparent dip of the fractures as seen in the 


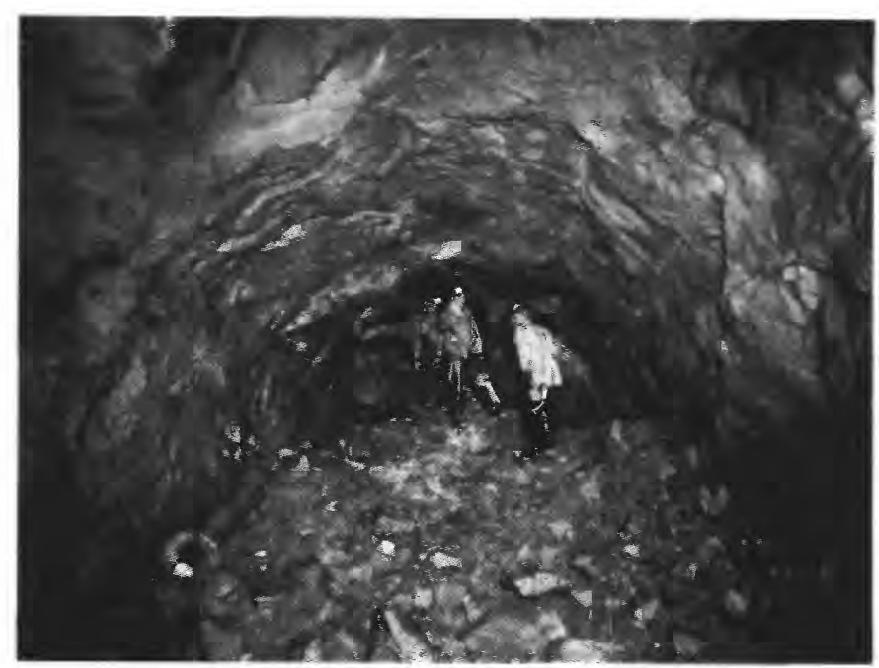

FIGURE 44.- Heading at station $458+46$ in massive Montezuma Quartz Monzonite.

tunnel heading. An ellipse with maximum and minimum dimensions inscribed in the plotted overbreak average has an ellipticity of 1.09 , a value near that for conspicuously bedded sedimentary rocks west of station $180+00$ (p. C15).

Plate $5 C$ illustrates the tunnel interval between stations $447+00$ and $448+40$ that contains a moderate number of joints and narrow slips. Argillic alteration follows the fractures and permitted disengagement of joint blocks that otherwise would have been adequately keyed in the arch because of rough surfaces on the joints. Overbreak in individual cross sections was erratic and was controlled by intersections of fractures, or breaking to single fractures subparallel to some portion of the tunnel and outside the payline.

The tunnel heading in the interval between stations $503+00$ and $504+40$ was driven southeast from the access shaft in closely and complexly fractured quartz monzonite (pl. $5 D$ ). Major fractures dipping both ways in the tunnel heading and closely spaced intricate sets of joints at intersections and between faults resulted in considerable overbreak in the arch. Although the average cross section is nearly symmetrical, the larger overbreak in the center and right upper arch resulted from the fact that during blasting the rock broke more readily to the fractures. The fractures entering the tunnel at the same angles on the left side of the tunnel had a small apparent angle.

Plate $5 E$ shows the geologic relationships that resulted in an average overbreak of more than 30 percent. Between stations $545+00$ and $546+40$, and elsewhere, the tunnel encountered successions of gently dipping faults accompanied by extensive jointing and argillic alteration. Although steel ribs on 5-foot centers and timber lagging were adequate to provide safe support, blasting produced exceptionally large overbreak, especially in the direction of the apparent dip of the faults in the tunnel headings. Breakage to or through flat faults in or near the arch resulted in the development of a peaked arch in many sections in the highly incompetent rock. The development of the peaked arch continued after the timber lagging was placed, but the materials sloughing from the arch fell on the lagging until self-supporting accumulations developed so as to prevent further raveling.

Fresh aplite associated with the Montezuma stock is a fine-grained, very hard, and brittle material. Drilling in the aplite was slow and difficult because of its hardness, and maximum blasting-powder charges were required to break the rock. Plate $5 F$ shows a tunnel section in moderately fractured aplite between stations $606+50$ and $607+90$. Overbreak in this interval was mainly the result of the heavy blasting operation required to break the rock and was influenced to only a slight degree by fractures intersecting the tunnel rocks. Joints of a sufficient number were present to require installation of light support.

Plate $5 G$ illustrates a tunnel interval in Precambrian biotite gneiss between stations $625+00$ and $626+40$. Fractures are widely spaced but contain sufficient altered minerals along joints to cause blocks to become detached from the arch. The strike of the foliation is nearly at right angles to the tunnel, and foliation dips steeply. The gneiss tended to split easily along foliation planes and with difficulty across the planes, so blast effects extended into the rock for short distances outside the payline. An arithmetic mean overbreak of 8.4 percent is well below the average as compared to other parts of the tunnel.

Although light to heavy support was required for most of the tunnel in the Montezuma stock, a few intervals, such as the one indicated on plate $5 H$, did not require support. This part of the tunnel is in aplite that is associated with the stock and contains a moderate number of tight fractures (between stas. $687+00$ and $688+40$ ). However, alteration along the fractures, where present, is not the argillic type, but consists of formation of thin zones of quartz and sericite next to narrow veins. Joints have rough surfaces and are well keyed into the arch of the tunnel. Previous experience with drilling and blasting in the aplite (pl. $5 F$ ) enabled advancement of the tunnel heading with minimum overbreak. An additional factor was the knowledge that the rock 
would not require supports and that it was not necessary to provide extra room on the sides of the tunnel for installation of the supports as in the tunnel interval between stations $606+50$ and $607+90$.

\section{FEELER HOLES, GROUND WATER, GROITING,} SUPPORTS, AND PROGRESS

A graphical summary of feeler-hole testing beyond the tunnel headings, amount of ground water encountered in the feeler holes, required grouting operations, required supports, and the rate of advance of the tunnel heading is shown on plate 1 (stas. $343+00$ to $690+00$ ). The same features at a larger scale are shown for representative parts of the tunnel on plates 10 and 11 .

The average rate of advance of the tunnel heading through the Montezuma stock was satisfactory. The absence of notable amounts of ground water, except in a few isolated fissures, contributed to the satisfactory rate of advance and is accounted for by the fact that although fractures are numerous and widespread, swelling argillic alteration associated with most of the fractures and gouge in many faults prevented the flow of surface water to tunnel level.

The notable lack of large volumes of ground water at tunnel level enabled advance of the tunnel heading without numerous time-consuming and costly delays for feeler-hole drilling and grouting operations. The heaviest waterflow was approximately 500 gallons per minute from a narrow open fissure near station $366+42$. (Water in the fissure was supplied by the Snake River about 650 feet above the tunnel.) The waterflow was stopped by pumping grout of 1,834 sacks of cement into the fissure. Several small flows from fissures in the vicinity of stations $550+00$ and $560+00$ contained carbon dioxide gas, which escaped from the water at the points of issuance and caused calcium carbonate to be deposited on the sides and floor of the tunnel.

Argillic alteration in several sections of the tunnel indicated as "EWO" (Extra work order) sections on plate 1 (stas. $343+00$ to $690+00$ ) did not present difficulty at the time it was encountered in the tunnel. Slow hydration and swelling caused dislocation of steel ribs and heaving of the haulage tract several weeks to several months after exposure and required installation of additional supports and realinement of existing supports under terms not specified in the documents and specifications of the original contract.
Steel supports were installed in the interval between stations $343+00$ and $686+50$ as indicated in the following table.

Supported sections. Stations $343+00$ to $686+50$

\begin{tabular}{cll}
\hline Stations & \multicolumn{1}{c}{ Rock type } & \multicolumn{1}{c}{$\begin{array}{c}\text { Support } \\
\text { (percent) }\end{array}$} \\
\hline $343+00$ to $347+50$ & $\begin{array}{c}\text { Border zone of Montezuma stock } \\
\text { containing hornfels inclusions. }\end{array}$ & 58.9 \\
$347+50$ to $625+00$ & $\begin{array}{l}\text { Quartz monzonite. } \\
\text { Biotite gneiss roof pendant in } \\
\text { stock. }\end{array}$ & 88.0 \\
$625+00$ to636+15 & 58.6 \\
$636+85$ to686+50 & Quartz monzonite. & 72.4 \\
\hline
\end{tabular}

Plate $10 A$ summarizes the tunneling operation as it is related to the geology between stations $354+00$ and $361+50$. Between stations $354+00$ and $359+30$, the moderately fractured quartz monzonite that contained numerous narrow aplite dikes required no support. The tunnel heading was advanced through this interval at a rate of as much as 53 feet per 24 hour period. Only two feeler holes were drilled and no water was encountered. Between stations $359+30$ and $361+50$, fractures and argillic alteration associated with a very strong fault at station $360+00$ necessitated installation of steel supports. Moist gouge and pulverized altered rock in and immediately adjacent to the fault induced squeezing and swelling in the rocks surrounding the tunnel; and steel sets with struts on 2.5-foot spacing and heavy timber lagging were installed to support the incompetent materials.

Plate $10 B$ illustrates a part of the tunnel in which numerous strong intersecting fractures are accompanied by pervasive argillic alteration consisting of montmorillonite and other clay minerals (stas. $424+50$ to $432+00$ ). The heading was advanced through this interval at a satisfactory rate with the installation of steel sets on 3.0-, 4.0-, and 5.0foot centers. The rocks were practically dry and only a few feeler holes were drilled in advance of the headings. Within a few months, slow swelling and squeezing of the argillized rocks were evidenced by dislocation of the steel and timber supports and by dislocation of the rails of the haulage track and by the slow caving of muddy, hydrated rock. Temporary remedial measures were taken to stabilize the haulage track, but stabilization of the swelling rock required installation of considerable additional steel and timber supports under the provisions of an extra work order (EWO). Within a year, hydration and 
swelling had advanced into the rocks surrounding the tunnel preventing further access of water vapor to unhydrated rocks; thus, the rate of swelling became insignificant.

Plate $10 C$ (stas. $442+00$ to $449+50$ ) shows a part of the tunnel in which concentrations of faults and joints (fractures) are localized. In contrast with those in the tunnel interval represented on plate $10 B$, the fractures are not accompanied by argillic alteration, and the quartz monzonite is hard and fresh. Joints have rough surfaces, but in some places they intersect in patterns tending to produce blocky ground. The strong faults contain dry, closely fractured rock and gouge and are accompanied by numerous closely spaced joints. Light support was installed where the rock was blocky or was shattered in and near strong faults.

The part of the tunnel between stations $502+50$ and $510+00$ was driven $\mathrm{S} .49^{\circ} 33^{\prime} \mathrm{E}$. from the access shaft (pl. 10D) in highly fractured, moderately soft, argillized quartz monzonite. At the time that the altered rocks were encountered only light steel and timber support was installed because, even though the rock was not hard and was complexly fractured, it tended to arch and did not collapse before supports could be installed. Hydration of montmorillonite in the altered rocks resulted in squeezing and dislocation of many of the supports, and in some intervals, actual failure of the supports. Stabilization of this tunnel section was accomplished by installing jump sets and struts, realinement of existing supports, and addition of timber lagging several months after the rocks were exposed by the tunneling operation.

Veins, faults, and joints intersect in a complex pattern in the part of the tunnel between stations $527+50$ and $535+00$ (pl. 11A). Mild argillic alteration is restricted to a short interval between stations $530+70$ and $540+50$. The veins contain quartz, carbonates, and metallic sulfides. Hard bleached zones in the walls of the veins were formed by introduction of sericite and fine-grained quartz into the quartz monzonite wallrock. Blocky rock at the intersection of the various sets of fractures required light support.

On plate $11 B$ the tunnel operations are correlated with geology in an interval that penetrated quartz monzonite of the Montezuma stock and Precambrian biotite gneiss and pegmatite in a roof pendant in the stock (stas. $632+50$ to $640+00$ ). The tunnel heading was advanced in a southeasterly direction from the access shaft (pl. 1). Faults and joints are widely spaced and the foliation of the gneiss is nearly at right angles to the tunnel. The rocks contained no water and feeler holes were not drilled. Joint surfaces were rough and generally the joint blocks were well keyed into the tunnel arch. Veins were narrow and were accompanied by narrow zones of introduced sericite and quartz. Light support was installed where joint sets intersected in such a way that blocks and slabs of rock could detach themselves from the tunnel arch.

Plate $11 C$ shows a part of the tunnel between stations $655+00$ and $662+50$. Blocky rock, resulting from intersection of clusters of joints and mild alteration along and near some of the veins and joints, required local installation of light support.

On plate $11 D$ that part of the tunnel is shown where it crosses the contact between the Montezuma stock and the Precambrian gneiss that contains granitic bodies (stas. $685+00$ to $692+50$ ). Widely spaced joints in both the quartz monzonite and associated aplite and the Precambrian rocks, the absence of alteration, and the otherwise competent nature of the rocks provided ideal tunneling conditions.

\section{GEOLOGY OF THE ACCESS SHAFT}

The access shaft was sunk to tunnel level at the site of an exploratory diamond drill hole and is at station $495+43.64$ (pl. 1). The collar elevation is $9,695.31$ feet, and the elevation of the tunnel invert at the bottom of the shaft is $8,779.85$ feet-a vertical difference in elevation of 915.46 feet. A muck pocket was sunk about 50 feet below the tunnel invert (fig. 45). The shaft was lined with concrete during the sinking operation to a circular cross section 16 feet in diameter. Headings were driven toward Dillon (the "Dillon heading") and toward Grant (the "Grant heading") from the bottom of the shaft which was used for access to all operations required in the driving of the two headings. The shaft was started on Oct. 11, 1956, and was completed to invert elevation on Oct. 1, 1957, nearly a year later.

Except for 27 feet of gravel and glacial deposits below the collar, the shaft is entirely in quartz monzonite and quartz monzonite aplite. Several faults and veins (fig. 46) were encountered in the sinking operation but, in general, because of their steep dips, caused little difficulty. Ground water in some of the fractures was sealed off by grouting through the concrete lining after it was placed. A report of the technical aspects of sinking the shaft has been prepared by Bolmer (1961). 


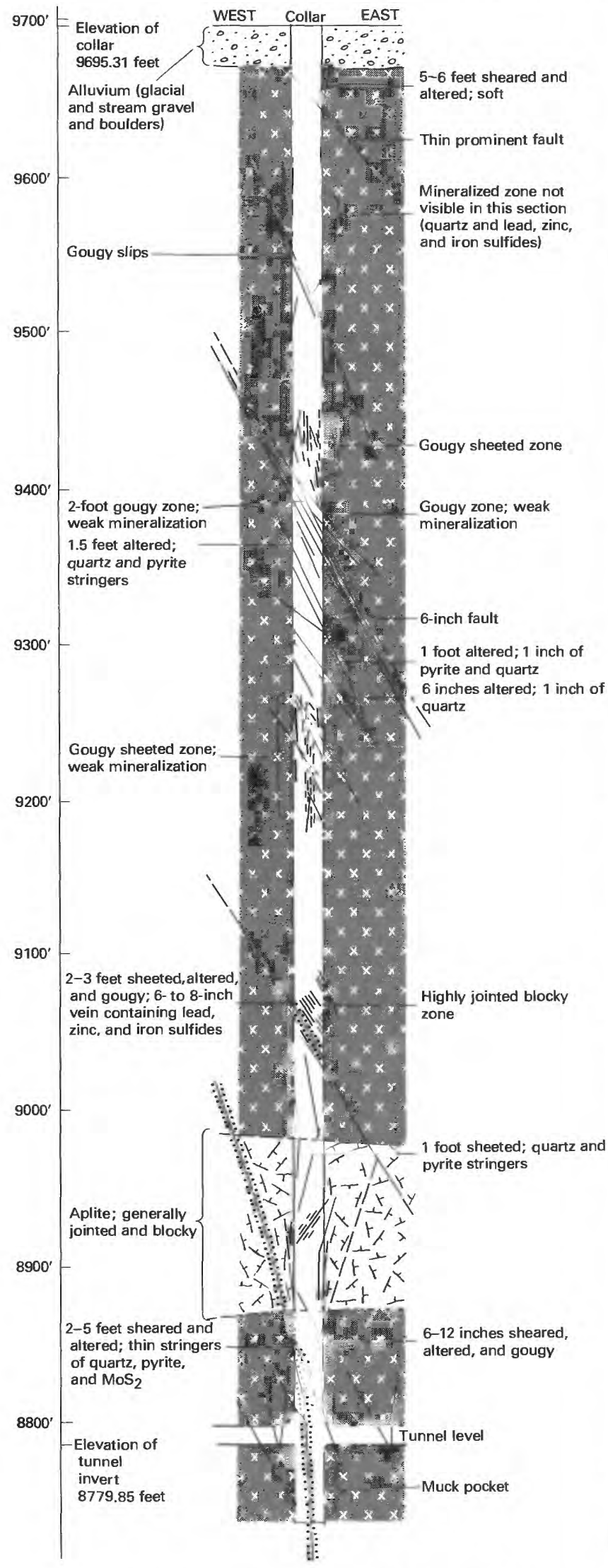

FIGURE 45.-Geologic section of access shaft parallel to tunnel tangent.

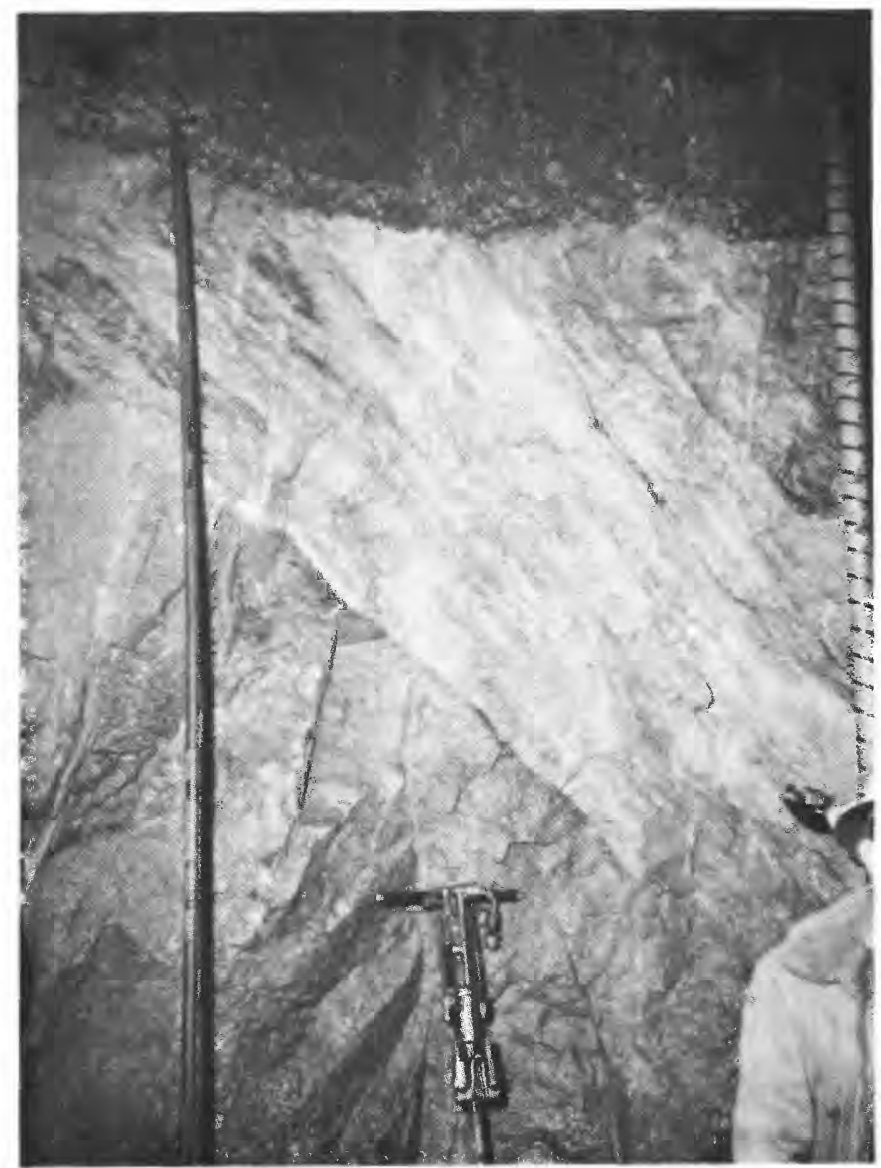

Figure 46.-Altered Montezuma Quartz Monzonite and vein in access shaft. Bottom of concrete lining in top of photograph is at altitude of 9,582 feet.

\section{REFERENCES CITED}

Bolmer, R. L., 1961, Sinking a largediameter, concretelined access shaft-Harold D. Roberts Tunnel, Colorado: U.S. Bur. Mines Inf. Circ. 8029, 70 p.

Crawford, R. D., 1924, A contribution to the igneous geology of central Colorado: Am. Jour. Sci., 5th ser., v. 7, p. 365-388.

Lambe, T. W., 1960, The character and identification of expansive Soils: Federal Housing Adm. Tech. Studies Rept. FHA 701, 46 p.

Lovering, T. S., 1935, Geology and ore deposits of the Montezuma quadrangle, Colorado: U.S. Geol. Survey Prof. Paper 178, 119 p.

Lovering, T. S., and Goddard, E. N., 1939, Geologic map of the Front Range Mineral Belt: Colorado Sci. Soc. Proc., v. 14, no. 1, p. $1-48,3$ pls.

Robinson, C. S., Warner, L. A., and Wahlstrom, E. E., 1974, General geology of the Harold D. Roberts Tunnel, Colorado: U.S. Geol. Survey Prof. Paper 831-B, 47 p.

Wahlstrom, E. E., 1974, History of geologic investigations, engineering design, and construction methods of the Harold D. Roberts Tunnel, Colorado: U.S. Geol. Survey Prof. Paper 831-A, 13 p.

Wahlstrom, E. E., and Hornback, V. Q., 1962, Geology of the Harold D. Roberts Tunnel, Colorado-West Portal to Station 468+49: Geol. Soc. America Bull., v. 73, no. 12, p. 1477-1498.

Wahlstrom, E. E., Robinson, C. S., and Nichols, T. C., 1968, Swelling of rocks in faults in the Roberts Tunnel, Colorado: Geol. Soc. America Eng. Geology Case Histories, no. 6, p. 83-89. 